Prepared in cooperation with the

Massachusetts Department of Environmental Protection

\title{
Simulated Responses of Streams and Ponds to Groundwater Withdrawals and Wastewater Return Flows in Southeastern Massachusetts
}

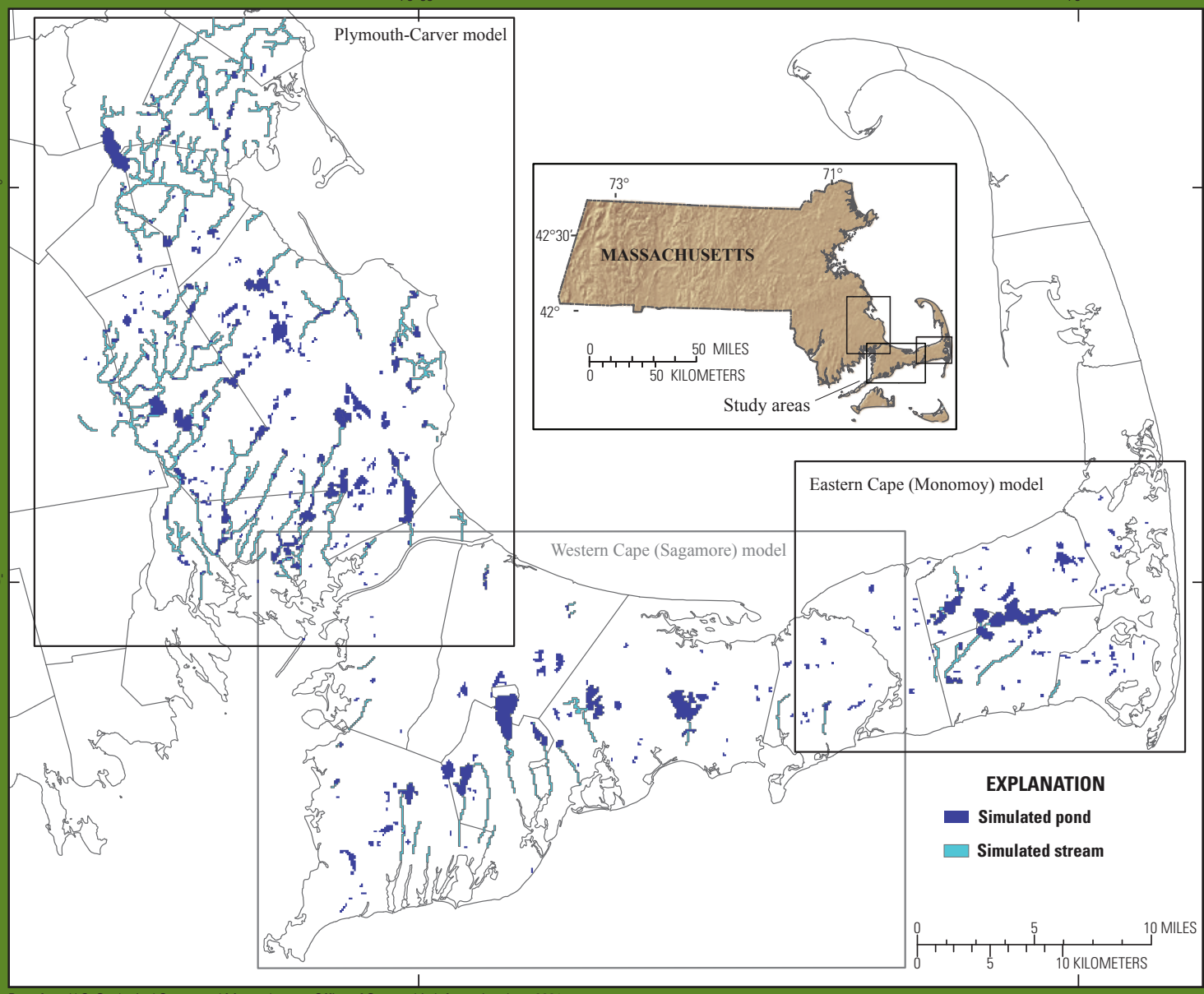

Scientific Investigations Report 2015-5168

U.S. Department of the Interior

U.S. Geological Survey 
Cover. Map showing the extents of the three regional groundwater flow models of the Plymouth-Carver, western Cape (Sagamore flow lens), and eastern Cape (Monomoy flow lens) aquifers in southeastern Massachusetts. 


\section{Simulated Responses of Streams and Ponds to Groundwater Withdrawals and Wastewater Return Flows in Southeastern Massachusetts}

By Carl S. Carlson, Donald A. Walter, and Jeffrey R. Barbaro

Prepared in cooperation with the

Massachusetts Department of Environmental Protection

Scientific Investigations Report 2015-5168 


\title{
U.S. Department of the Interior SALLY JEWELL, Secretary
}

\section{U.S. Geological Survey Suzette M. Kimball, Acting Director}

\author{
U.S. Geological Survey, Reston, Virginia: 2015
}

For more information on the USGS - the Federal source for science about the Earth, its natural and living resources, natural hazards, and the environment-visit http://www.usgs.gov/ or call 1-888-ASK-USGS.

For an overview of USGS information products, including maps, imagery, and publications, visit http://www.usgs.gov/pubprod/.

Any use of trade, firm, or product names is for descriptive purposes only and does not imply endorsement by the U.S. Government.

Although this information product, for the most part, is in the public domain, it also may contain copyrighted materials as noted in the text. Permission to reproduce copyrighted items must be secured from the copyright owner.

Suggested citation:

Carlson, C.S., Walter, D.A., and Barbaro, J.R., 2015, Simulated responses of streams and ponds to groundwater withdrawals and wastewater return flows in southeastern Massachusetts: U.S. Geological Survey Scientific Investigations Report 2015-5168, 60 p., http://dx.doi.org/10.3133/sir20155168.

ISSN 2328-0328 (online) 


\section{Contents}

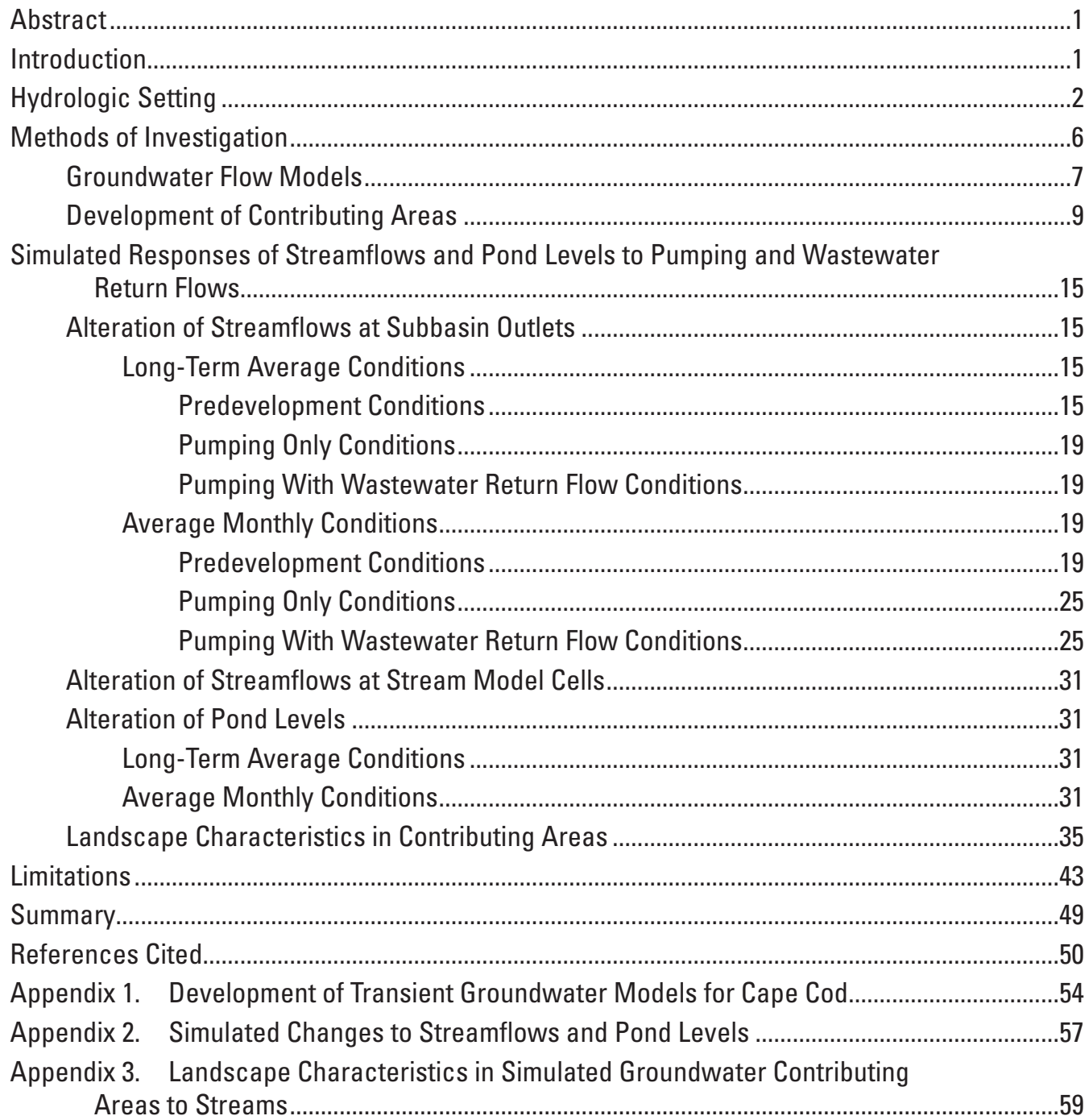

\section{Figures}

1. Map showing the extents of the three regional groundwater flow models of the Plymouth-Carver, western Cape, and eastern Cape aquifers in southeastern Massachusetts.

2. Map showing distribution of wastewater return flow areas and production well locations for pumping and recharge conditions in the Plymouth-Carver model area in southeastern Massachusetts from 2000 through 2005

3. Map showing distribution of areal recharge, wastewater return flow areas, and production well locations for pumping and recharge conditions in the western Cape and eastern Cape models in southeastern Massachusetts for 2003. 
4. Schematic diagram showing generalized groundwater contributing areas in southeastern Massachusetts defined as $A$, hydrologic units and $B$, subbasins for simulating responses of streams and ponds to groundwater withdrawals and wastewater return flows.

5. Map showing simulated hydrologic units for streams and surface-water-connected ponds in the Plymouth-Carver, western Cape, and eastern Cape model areas in southeastern Massachusetts

6. Map showing simulated headwater subbasins for streams and surface-waterconnected ponds in the Plymouth-Carver, western Cape, and eastern Cape model areas in southeastern Massachusetts

7. Map showing simulated subbasins for streams and surface-water-connected ponds in the Plymouth-Carver, western Cape, and eastern Cape model areas in southeastern Massachusetts

8. Graph showing simulated long-term average streamflows for predevelopment, pumping only, and pumping with wastewater return flow conditions for each subbasin in the Plymouth-Carver, western Cape, and eastern Cape model areas in southeastern Massachusetts

9. Graph showing simulated long-term average streamflows normalized by subbasin area for predevelopment, pumping only, and pumping with wastewater return flow conditions for subbasins in the Plymouth-Carver, western Cape, and eastern Cape model areas in southeastern Massachusetts

10. Graphs showing percentage simulated changes in long-term average streamflow at the outlets of subbasins in southeastern Massachusetts from predevelopment conditions for $A$, pumping only or $B$, pumping with wastewater return flow conditions at the outlet of each subbasin

11. Graph showing August streamflows under predevelopment, pumping only, and pumping with wastewater return flow conditions at subbasin outlets in the Plymouth-Carver, western Cape, and eastern Cape model areas in southeastern Massachusetts.

12. Graph showing August streamflows normalized by subbasin area under predevelopment, pumping only, and pumping with wastewater return flow conditions at subbasin outlets in the Plymouth-Carver, western Cape, and eastern Cape model areas in southeastern Massachusetts

13. Graph showing simulated percentage alteration of average monthly streamflows for subbasins in the Plymouth-Carver, western Cape, and eastern Cape model areas in southeastern Massachusetts

14. Map view of simulated alteration of average August streamflow for subbasins in the Plymouth-Carver, western Cape, and eastern Cape model areas in southeastern Massachusetts for pumping only conditions compared with predevelopment conditions at the outlet of each subbasin

15. Graph showing simulated alterations of August streamflows for pumping only and pumping and wastewater return flow conditions compared with predevelopment conditions in the Plymouth-Carver, western Cape, and eastern Cape model areas in southeastern Massachusetts.

16. Graph showing simulated alterations in average January, April, August, and October streamflows for pumping with wastewater return flow conditions compared with predevelopment conditions at the outlets of subbasins in the Plymouth-Carver, western Cape, and eastern Cape model areas in southeastern Massachusetts.

17. Map view of simulated alterations of average August streamflow for subbasins in the Plymouth-Carver, western Cape, and eastern Cape model areas in southeastern Massachusetts for pumping with wastewater return flow conditions compared with predevelopment conditions at the outlet of each subbasin 
18. Maps showing simulated effects of pumping with wastewater return flow on average August streamflow in stream cells in the Plymouth-Carver model area in southeastern Massachusetts compared with streamflows under predevelopment conditions $A$, in absolute values and $B$, as percentage change...

19. Maps showing simulated effects of pumping with wastewater return flow on average August streamflow in stream cells in the western Cape model area in southeastern Massachusetts compared with streamflows under predevelopment conditions $A$, in absolute values and $B$, as percentage change

20. Maps showing simulated effects of pumping with wastewater return flow on average August streamflows in stream cells in the eastern Cape model area in southeastern Massachusetts compared with streamflows under predevelopment conditions $A$, in absolute values and $B$, as percentage change...

21. Maps showing simulated changes to average August pond water levels due to $A$, pumping only and $B$, pumping with wastewater return flow conditions for the Plymouth-Carver model area in southeastern Massachusetts

22. Maps showing simulated changes to average August pond water levels due to $A$, pumping only and $B$, pumping with wastewater return flow conditions for the western Cape model area in southeastern Massachusetts

23. Maps showing simulated changes to average August pond water levels due to $A$, pumping only and $B$, pumping with wastewater return flow conditions for the eastern Cape model area in southeastern Massachusetts ..

24. Hydrographs from the Plymouth-Carver model area of simulated average monthly pond levels for predevelopment, pumping only, and pumping with wastewater return flow conditions for $A$, Goose Pond and $B$, Triangle Pond in southeastern Massachusetts.

25. Graphs showing comparison of $A$, channel slope, $B$, percent wetland in a 787.4-foot buffer, $C$, August withdrawal ratio, and $D$, percent impervious cover for Massachusetts water indicator subbasins, fish sampling site subbasins, and southeastern Massachusetts hydrologic units and subbasins . .41

26. Graphs showing comparison of $A$, percent forest, $B$, drainage area, $C$, percent sand and gravel, $D$, undammed stream length, and $E$, percent open water for fish sampling site subbasins and southeastern Massachusetts subbasins.

27. Maps showing simulated effect of pumping and percentage change on November streamflow compared with predevelopment conditions for $A$, the existing model and $B$, the alternative analysis with no pond outlet flow from Silver Lake to the Jones River area in southeastern Massachusetts. . .44

28. Maps showing simulated effect of pumping with wastewater return flows and percentage change on November streamflow compared with predevelopment conditions for $A$, the existing model and $B$, the alternative analysis with no pond outlet flow from Silver Lake to the Jones River area in southeastern Massachusetts.

29. Graphs showing simulated November streamflow and change in November streamflow compared with predevelopment conditions for two sites on the Jones River from simulations of $A$, existing model and $B$, the alternative analysis with no pond outlet flow from Silver Lake to the Jones River in southeastern Massachusetts. 


\section{Tables}

1. Simulated hydrologic budget for predevelopment and for pumping only and pumping with wastewater return flow conditions from 2000 through 2005 in the Plymouth-Carver aquifer system in southeastern Massachusetts

2. Simulated hydrologic budget for predevelopment and for pumping only and pumping with wastewater return flow conditions in 2003 in the western Cape and eastern Cape models of Cape Cod in southeastern Massachusetts..

3. Stream identification, landscape characteristics, and simulated average streamflows for hydrologic units and subbasins in southeastern Massachusetts (Click here for link to http://dx.doi.org/10.3133/sir20155168)

4. Percent impervious cover and long-term average streamflow for hydrologic units in southeastern Massachusetts (Click here for link to http://dx.doi.org/10.3133/ sir20155168).

5. Summary of maximum simulated streamflows and the percentages of stream cells with streamflows within specific ranges under predevelopment conditions for long-term average and monthly simulations of the Plymouth-Carver, western Cape, and eastern Cape models in southeastern Massachusetts.

6. Summary of changes in pond levels under pumping only and pumping with wastewater return flow conditions compared with predevelopment conditions for the Plymouth-Carver, western Cape, and eastern Cape models in southeastern Massachusetts.

7. Simulated streamflows for predevelopment, pumping only, and pumping with wastewater return flow conditions for long-term average and average January, April, August, and October conditions for the existing models and the alternative analysis with no pond outlet flow for the Plymouth-Carver and western Cape model areas, southeastern Massachusetts..

\section{Conversion Factors}

Inch/Pound to International System of Units

\begin{tabular}{|c|c|c|}
\hline Multiply & By & To obtain \\
\hline \multicolumn{3}{|c|}{ Length } \\
\hline foot $(\mathrm{ft})$ & 0.3048 & meter $(\mathrm{m})$ \\
\hline mile (mi) & 1.609 & kilometer $(\mathrm{km})$ \\
\hline \multicolumn{3}{|c|}{ Area } \\
\hline square mile $\left(\mathrm{mi}^{2}\right)$ & 2.590 & square kilometer $\left(\mathrm{km}^{2}\right)$ \\
\hline \multicolumn{3}{|c|}{ Flow rate } \\
\hline cubic foot per second $\left(\mathrm{ft}^{3} / \mathrm{s}\right)$ & 0.02832 & cubic meter per second $\left(\mathrm{m}^{3} / \mathrm{s}\right)$ \\
\hline $\begin{array}{l}\text { cubic foot per second per square mile } \\
\qquad\left(\left[\mathrm{ft}^{3} / \mathrm{s}\right] / \mathrm{mi}^{2}\right)\end{array}$ & 0.01093 & $\begin{array}{l}\text { cubic meter per second per square } \\
\text { kilometer }\left(\left[\mathrm{m}^{3} / \mathrm{s}\right] / \mathrm{km}^{2}\right)\end{array}$ \\
\hline cubic foot per day $\left(\mathrm{ft}^{3} / \mathrm{d}\right)$ & 0.02832 & cubic meter per day $\left(\mathrm{m}^{3} / \mathrm{d}\right)$ \\
\hline million gallons per day (Mgal/d) & 0.04381 & cubic meter per second $\left(\mathrm{m}^{3} / \mathrm{s}\right)$ \\
\hline inch per year (in/yr) & 25.4 & millimeter per year (mm/yr) \\
\hline
\end{tabular}




\section{Datum}

Vertical coordinate information is referenced to the North American Vertical Datum of 1988

(NAVD 88).

Horizontal coordinate information is referenced to the North American Datum of 1983 (NAD 83), unless otherwise noted.

\section{Abbreviations}

GIS geographic information system

STR Streamflow-Routing [package]

USGS U.S. Geological Survey

WMA Massachusetts Water Management Act 



\title{
Simulated Responses of Streams and Ponds to Groundwater Withdrawals and Wastewater Return Flows in Southeastern Massachusetts
}

\author{
By Carl S. Carlson, Donald A. Walter, and Jeffrey R. Barbaro
}

\section{Abstract}

Water use, such as withdrawals, wastewater return flows, and interbasin transfers, can alter streamflow regimes, water quality, and the integrity of aquatic habitat and affect the availability of water for human and ecosystem needs. To provide the information needed to determine alteration of streamflows and pond water levels in southeastern Massachusetts, existing groundwater models of the PlymouthCarver region and western (Sagamore flow lens) and eastern (Monomoy flow lens) Cape Cod were used to delineate subbasins and simulate long-term average and average monthly streamflows and pond levels for a series of wateruse conditions. Model simulations were used to determine the extent to which streamflows and pond levels were altered by comparing simulated streamflows and pond levels under predevelopment conditions with streamflows and pond levels under pumping only and pumping with wastewater return flow conditions. The pumping and wastewater return flow rates used in this study are the same as those used in previously published U.S. Geological Survey studies in southeastern Massachusetts and represent the period from 2000 to 2005. Streamflow alteration for the nontidal portions of streams in southeastern Massachusetts was evaluated within and at the downstream outlets of 78 groundwater subbasins delineated for this study. Evaluation of streamflow alteration at subbasin outlets is consistent with the approach used by the U.S.

Geological Survey for the topographically derived subbasins in the rest of Massachusetts.

The net effect of pumping and wastewater return flows on streamflows and pond levels varied by location and included no change in areas minimally affected by water use, decreases in areas affected more by pumping than by wastewater return flows, or increases in areas affected more by wastewater return flows than by pumping. Simulated alterations to longterm average streamflows at subbasin outlets in response to pumping with wastewater return flows were within about 10 percent of predevelopment streamflows for most of the subbasins in the study area. Alterations ranged from a decrease (depletion) of 43.9 percent at an unnamed tributary to Salt
Pond in the Plymouth-Carver region to an increase (surcharge) of 18.2 percent at an unnamed tributary to the Centerville River on western Cape Cod. In general, the relative effects of pumping and wastewater return flows typically were larger in the subbasins with low streamflows than in the subbasins with high streamflows, and there were more depleted streamflows than surcharged streamflows. Increases in streamflows in response to wastewater return flows were generally largest in subbasins with a high density of septic systems or a centralized wastewater treatment facility. For average monthly conditions, streamflow alteration results were similar spatially to results for long-term average conditions. However, differences in the extent of alteration by month were observed; percentage streamflow depletions in most subbasins typically were greatest during the low-streamflow months of August and October.

The percentages of the total number of ponds affected by pumping with wastewater return flows under long-term average conditions in the modeled areas were 28 percent for the Plymouth-Carver region, 67 percent for western Cape Cod, and 75 percent for eastern Cape Cod. Pond-level alterations ranged from a decrease of 4.6 feet at Great South Pond in the Plymouth Carver region to an increase of 0.9 feet at Wequaquet Lake in western Cape Cod. The magnitudes of monthly alterations to pond water levels were fairly consistent throughout the year.

\section{Introduction}

Water use, such as withdrawals, wastewater return flows, and interbasin transfers, can alter streamflow regimes, water quality, and the integrity of aquatic habitat and affect the availability of water for human and ecosystem needs. In Massachusetts, concern has grown in recent years about the potential effects of alteration on water availability and aquatic habitat and the need for improved indicators of hydrologic alteration. In 2010, the U.S. Geological Survey (USGS) developed methods for estimating indicators of streamflow alteration and other measures of drainage-basin alteration for 
Simulated Responses of Streams and Ponds to Groundwater Withdrawals and Wastewater Return Flows in Mass.

1,379 subbasins in Massachusetts (Weiskel and others, 2010; Massachusetts Department of Environmental Protection, 2014a). In 2011, the USGS determined relations between fish assemblages and anthropogenic factors (such as estimated streamflow alteration) and physical basin characteristics (such as land use and impervious cover) for 669 fish sampling sites in Massachusetts (Armstrong and others, 2011). These studies were used in part as scientific support for 2014 revisions to the Massachusetts Water Management Act (WMA; Massachusetts General Court, 2015) regulations; the WMA provides the basis for the regulatory framework that governs water allocations in Massachusetts. Although the USGS studies are considered to be statewide assessments of potential indicators of basin alteration, they are limited by a lack of streamflow and physical basin characteristic data in southeastern Massachusetts, preventing this area from being fully incorporated into the revised WMA regulatory framework.

The coastal plain of southeastern Massachusetts, which consists of the Plymouth-Carver region and Cape Cod (collectively referred to as southeastern Massachusetts in this report), differs from the rest of the Commonwealth in terms of topographic relief and aquifer size. The coastal plain is dominated by large sand and gravel aquifers and characterized by subdued topographic relief, whereas the rest of Massachusetts is underlain by smaller valley-fill aquifers in drainage basins with greater topographic relief. In southeastern Massachusetts, contributing areas to streams are referred to as groundwater subbasins because their size is determined largely by groundwater recharge rather than topographic divides. For the statewide assessments of Weiskel and others (2010) and Armstrong and others (2011), the Sustainable Yield Estimator application (Archfield and others, 2010) was used to estimate streamflow in subbasins delineated by topographic relief. However, the Sustainable Yield Estimator is not applicable to areas of low topographic relief in southeastern Massachusetts where groundwater and surface-water divides are not coincident (Archfield and others, 2010). Consequently, the statewide assessments of indicators of streamflow and basin alteration did not include southeastern Massachusetts. Weiskel and others (2010) did estimate subbasins for 34 streams in southeastern Massachusetts, but because these areas and their associated basin alteration indicators were determined for the entire nontidal portions of these streams, these results were not sufficiently detailed for the WMA regulatory framework.

To provide the information needed to determine alteration of streamflows and pond water levels in southeastern Massachusetts, the USGS, in cooperation with the Massachusetts Department of Environmental Protection (MassDEP), conducted a study (fig. 1) that made use of the existing groundwater models of the Plymouth-Carver region (Masterson and others, 2009) and western (Sagamore flow lens) and eastern (Monomoy flow lens) Cape Cod (Walter and Whealan, 2005; Walter and Masterson, 2011). Groundwater models were used to delineate subbasins and simulate streamflow and pond levels for various water-use conditions. A streamflow criterion was used to divide the nontidal portions of streams in southeastern Massachusetts into subbasins of similar size to those used in Weiskel and others (2010) for the rest of Massachusetts; a total of 78 groundwater subbasins were delineated for the nontidal portion of streams in southeastern Massachusetts by using this approach. Streamflow and pond-level alterations were calculated relative to a predevelopment (without pumping or wastewater return flow) baseline condition. Simulations were conducted for both long-term average and average monthly conditions. Streamflow alterations were computed at the outlets of the 78 groundwater subbasins and at individual groundwater model cells used to represent the stream network in southeastern Massachusetts. Selected landscape characteristics computed for the topographically derived basins in the rest of Massachusetts were also determined for the 78 groundwater subbasins delineated in this study.

This report describes the methodology and results of the simulations used to evaluate the response of streams and ponds to withdrawals and wastewater return flows in southeastern Massachusetts. The report also describes the previously published groundwater flow models used in the analysis, the procedures used to delineate the areas of the groundwater subbasins that drain to selected outlet points, and the simulated changes in streamflows and pond levels in the coastal aquifers of southeastern Massachusetts in response to pumping only and pumping with wastewater return flows. The results in this report are expected to provide water resources managers with the information needed for estimating indicators of hydrologic alteration in southeastern Massachusetts.

\section{Hydrologic Setting}

The Plymouth-Carver aquifer system (fig. 2) is bounded laterally to the east and south by the saline surface waters of Cape Cod Bay and Cape Cod Canal. Drainage divides of the South and Green Harbor Rivers to the north and of the Winnetuxet and Weweantic Rivers to the west were used in Masterson and others (2009) to represent the northern and western boundaries of this aquifer system (fig. 2). The total active modeled area is about 290 square miles $\left(\mathrm{mi}^{2}\right)$. The groundwater flow systems on western and eastern Cape Cod (Sagamore and Monomoy flow lenses, respectively) are surrounded entirely by saline water-Atlantic Ocean to the east, Cape Cod Bay to the north, Cape Cod Canal to the northwest, Buzzard's Bay to the west, and Vineyard Sound to the south (Walter and Whealan, 2005) (fig. 3). These two flow lenses are separated hydraulically by the Bass River. The total active modeled area for Cape Cod aquifers is about $361 \mathrm{mi}^{2}$.

The sole source of freshwater to the aquifer systems of southeastern Massachusetts is precipitation. The part of precipitation that is not lost to evaporation or the transpiration of plants and reaches the water table is referred to as aquifer recharge. An average recharge rate of 27 inches per year (in/yr) was used in the previously published groundwater 


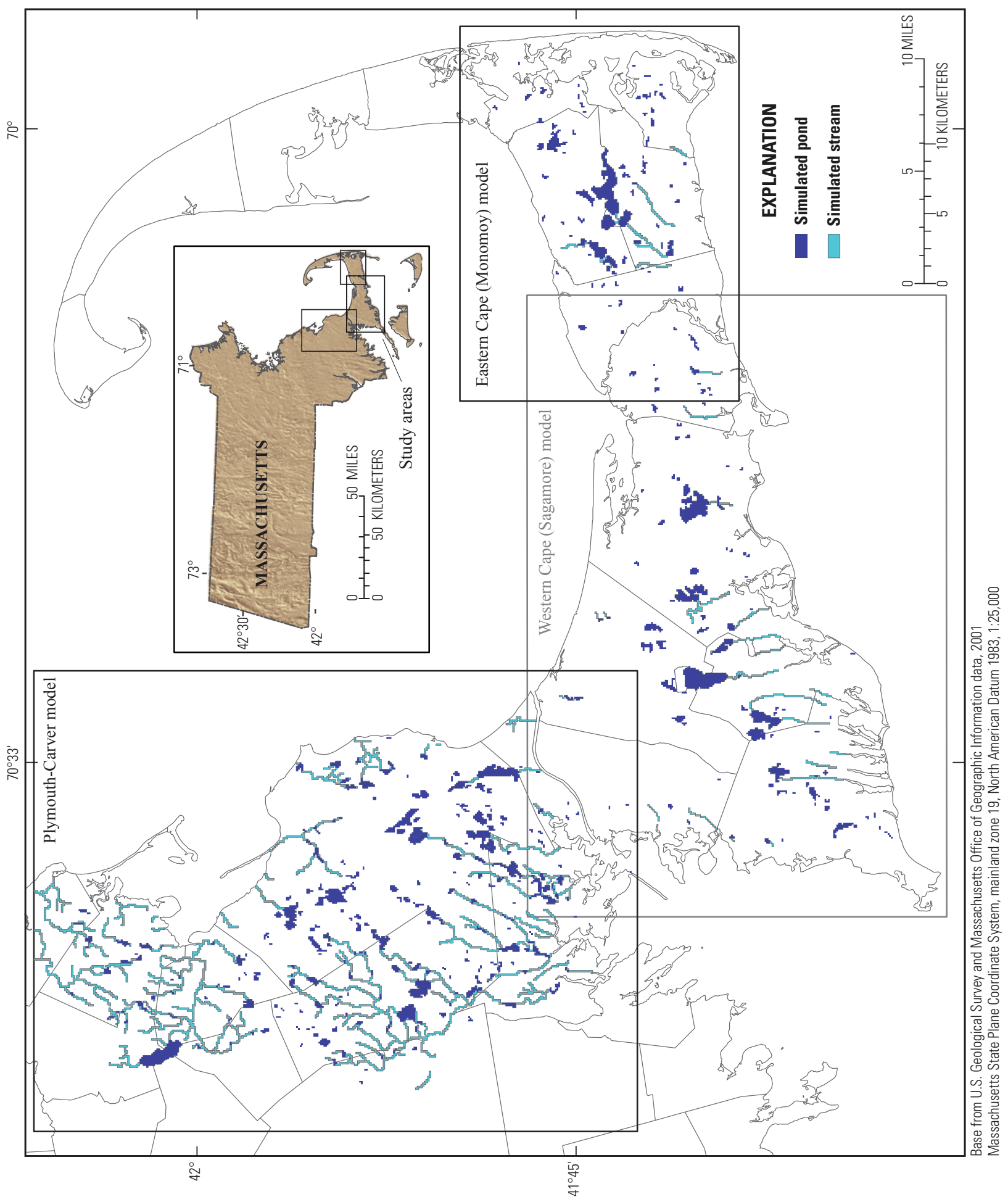




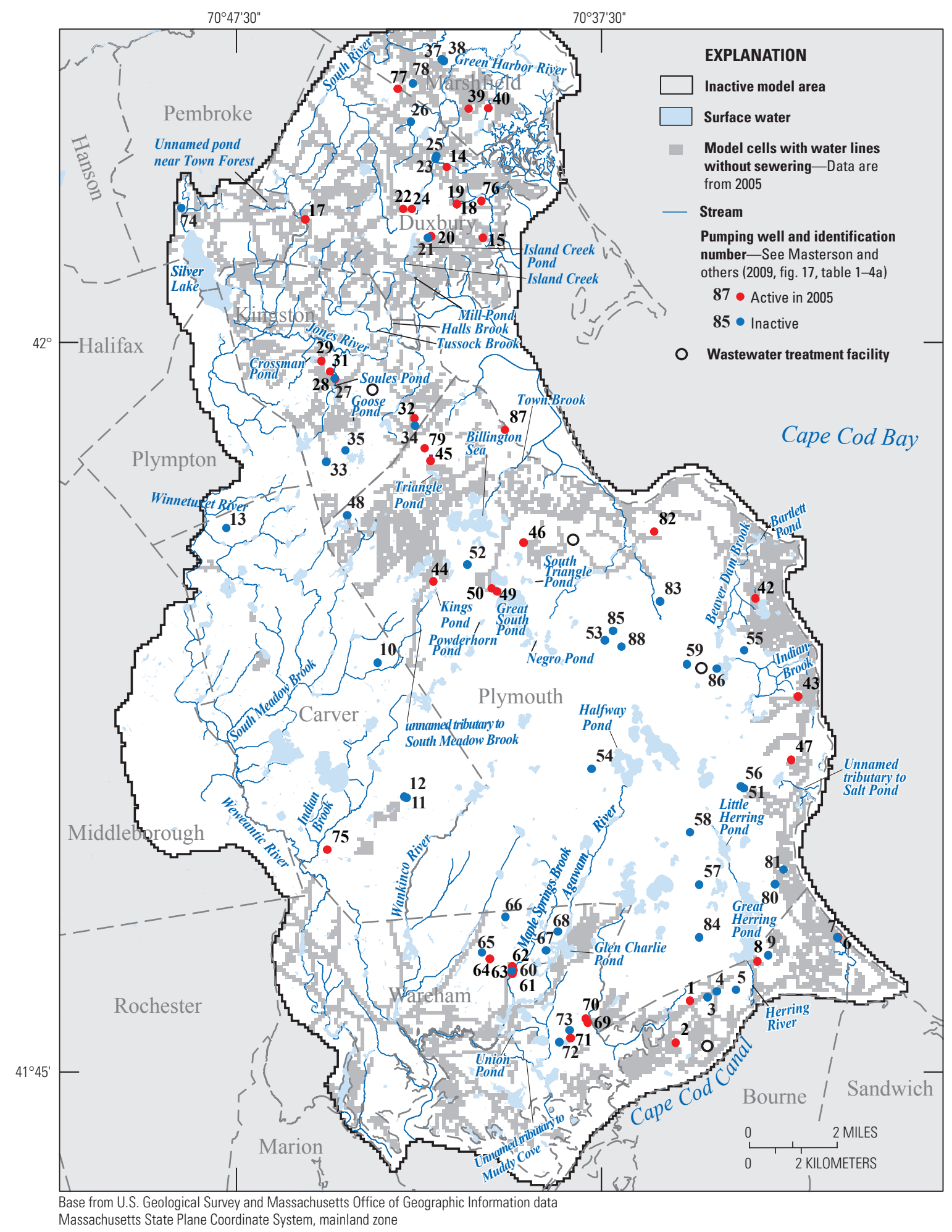

Figure 2. Distribution of wastewater return flow areas and production well locations for pumping and recharge conditions in the Plymouth-Carver model area in southeastern Massachusetts from 2000 through 2005. Modified from Masterson and others (2009, fig. 14). 


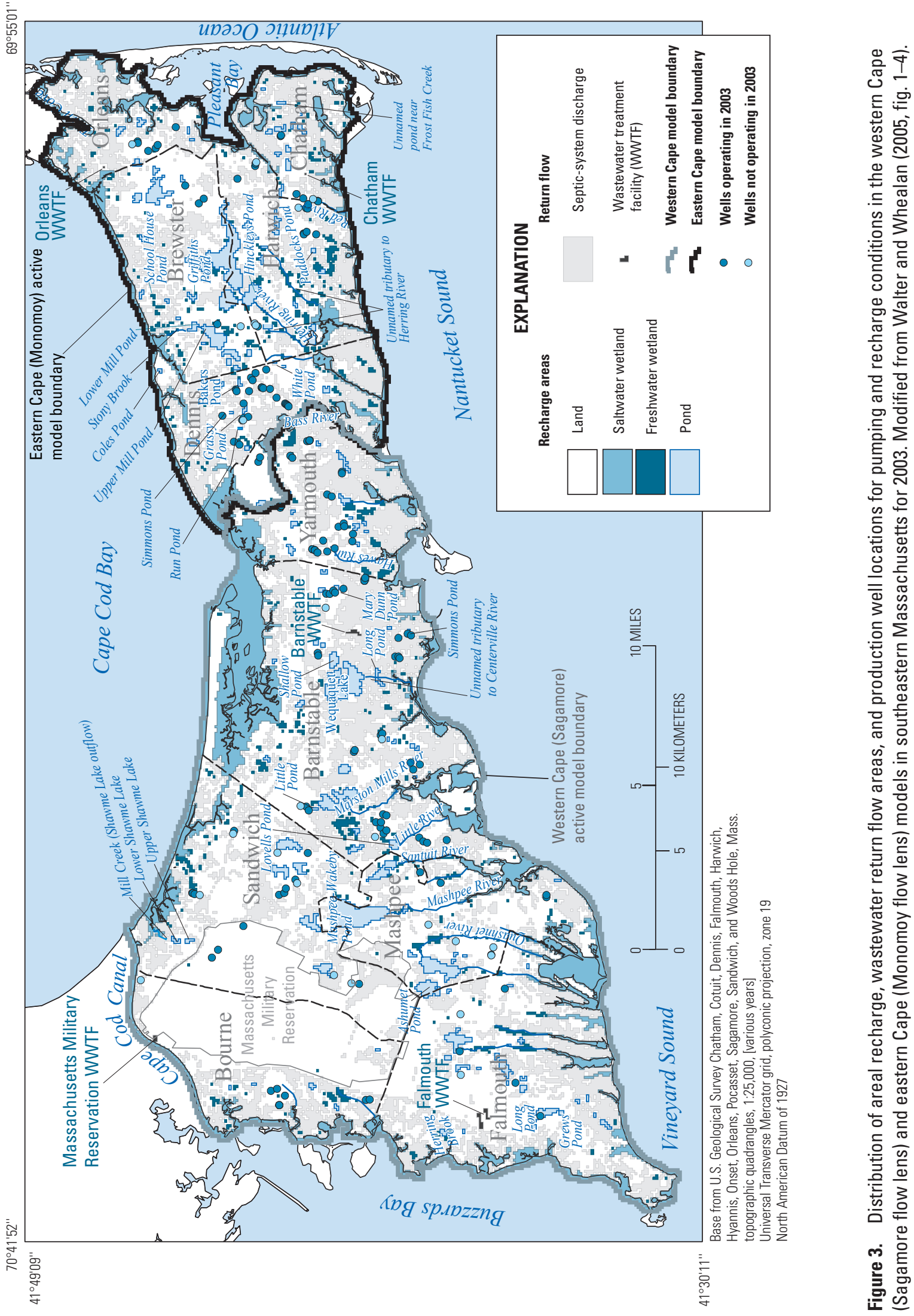


Simulated Responses of Streams and Ponds to Groundwater Withdrawals and Wastewater Return Flows in Mass.

models of southeastern Massachusetts (Walter and Whealan, 2005; Masterson and others, 2009). All the water that flows through the aquifer and discharges to ponds, streams, coastal areas, and production wells is derived from aquifer recharge. Groundwater flows from regional water-table divides toward natural discharge boundaries at streams and coastal water bodies; some water flows through ponds before discharging, and some water is removed from the system for water supply.

Model-calculated water budgets indicate that, for 2005 conditions, approximately 297.3 million gallons per day (Mgal/d) of water (from an average recharge rate of $27 \mathrm{in} / \mathrm{yr}$ plus recharge from wastewater) recharges the aquifer system in the Plymouth-Carver region (table 1). About 70 percent (209.7 Mgal/d) of this water moves through the aquifer, discharges to streams, and then flows to the coast. The remaining 30 percent is distributed into two categories: water that enters the aquifer as recharge then discharges directly to coastal areas ( 25 percent or $73.4 \mathrm{Mgal} / \mathrm{d}$ ) and water that is withdrawn at production wells (5 percent or $14.4 \mathrm{Mgal} / \mathrm{d}$ ).

On Cape Cod, groundwater flows outward from regional groundwater divides toward natural discharge locations at streams, coastal estuaries, and the ocean. Most of the groundwater flows through shallow sediments and discharges to streams and estuaries; groundwater recharging the aquifer near the central groundwater divides flows deep in the aquifer and discharges into the open saltwater bodies (fig. 3). Modelcalculated water budgets for the combined simulations of the western and eastern Cape indicate that, for conditions as of 2003, about $380 \mathrm{Mgal} / \mathrm{d}$ (from an average recharge rate of $27 \mathrm{in} / \mathrm{yr}$ plus recharge from wastewater plus inflow to the aquifer from streams) of water recharges the aquifer at the water table in this area (table 2); most water (about 65 percent) discharges at the coast, and about 28 percent discharges into streams. A total of about $24.9 \mathrm{Mgal} / \mathrm{d}$, or about 7 percent, of water in the aquifer is withdrawn for water supply (table 2). Most pumped water is returned to the hydrologic system as wastewater return flow.

\section{Methods of Investigation}

Previously published groundwater flow models of three regional aquifers in southeastern Massachusetts (fig. 1) were used in this study to determine the responses of streams at various scales (from an individual stream cell to the scale of a subbasin) and ponds to withdrawals and wastewater return flows. The previously published groundwater flow models were developed to provide information on regionalscale flow that included changes in groundwater levels, pond levels, and streamflows in response to changing pumping and recharge conditions in southeastern Massachusetts. The purpose and analyses of the previously published groundwater flow models and the purpose and analyses of the simulations in this study are similar, and therefore the previously published groundwater flow models, with some modification (appendix 1), were deemed appropriate for this study.

Table 1. Simulated hydrologic budget for predevelopment and for pumping only and pumping with wastewater return flow conditions from 2000 through 2005 in the Plymouth-Carver aquifer system in southeastern Massachusetts.

[Modified from Masterson and others (2009, table 2). Mgal/d, million gallons per day; NA, not applicable]

\begin{tabular}{|c|c|c|c|c|}
\hline & \multicolumn{2}{|c|}{ Predevelopment } & \multicolumn{2}{|c|}{2005} \\
\hline & $\begin{array}{c}\text { Flow, } \\
\text { in Mgal/d }\end{array}$ & $\begin{array}{c}\text { Percentage } \\
\text { of total }\end{array}$ & $\begin{array}{c}\text { Flow, } \\
\text { in Mgal/d }\end{array}$ & $\begin{array}{c}\text { Percentage } \\
\text { of total }\end{array}$ \\
\hline \multicolumn{5}{|c|}{ Inflow } \\
\hline Recharge & 289.9 & 100 & 289.9 & 98 \\
\hline Wastewater & 0 & 0 & 7.4 & 2 \\
\hline Total & 289.9 & 100 & 297.3 & 100 \\
\hline \multicolumn{5}{|c|}{ Outflow } \\
\hline Streams & 216.8 & 75 & 209.7 & 70 \\
\hline Coast & 73.4 & 25 & 73.4 & 25 \\
\hline Pumping wells & 0 & 0 & 14.4 & 5 \\
\hline Total & 290.2 & 100 & 297.5 & 100 \\
\hline Numerical model error & 0.3 & NA & 0.2 & NA \\
\hline
\end{tabular}


Table 2. Simulated hydrologic budget for predevelopment and for pumping only and pumping with wastewater return flow conditions in 2003 in the western Cape (Sagamore flow lens) and eastern Cape (Monomoy flow lens) models of Cape Cod in southeastern Massachusetts.

[Modified from Walter and Whealan (2005, table 1). Mgal/d, million gallons per day]

\begin{tabular}{|c|c|c|c|c|}
\hline & \multicolumn{2}{|c|}{ Predevelopment } & \multicolumn{2}{|c|}{2003} \\
\hline & $\begin{array}{c}\text { Flow, } \\
\text { in Mgal/d }\end{array}$ & $\begin{array}{c}\text { Percentage } \\
\text { of total }\end{array}$ & $\begin{array}{c}\text { Flow, } \\
\text { in } \mathrm{Mgal} / \mathrm{d}\end{array}$ & $\begin{array}{c}\text { Percentage } \\
\text { of total }\end{array}$ \\
\hline \multicolumn{5}{|c|}{ Sagamore flow lens } \\
\hline \multicolumn{5}{|c|}{ Inflow } \\
\hline Recharge & 252.1 & 99 & 252.1 & 94 \\
\hline Wastewater & 0 & 0 & 14.8 & 5 \\
\hline Streams & 2.3 & 1 & 2.3 & 1 \\
\hline Total & 254.3 & & 269.2 & \\
\hline \multicolumn{5}{|c|}{ Outflow } \\
\hline Estuaries & 105.8 & 42 & 105.4 & 39 \\
\hline Coast & 71.6 & 28 & 72.3 & 27 \\
\hline Streams & 77 & 30 & 74.2 & 28 \\
\hline Pumping wells & 0 & 0 & 17.3 & 7 \\
\hline Total & 254.4 & & 269.2 & \\
\hline \multicolumn{5}{|c|}{ Monomoy flow lens } \\
\hline \multicolumn{5}{|c|}{ Inflow } \\
\hline Recharge & 103.2 & 99 & 103.2 & 93 \\
\hline Wastewater & 0 & 0 & 6.5 & 6 \\
\hline Streams & 0.9 & 1 & 0.9 & 1 \\
\hline Total & 104.1 & & 110.6 & \\
\hline \multicolumn{5}{|c|}{ Outflow } \\
\hline Estuaries & 46 & 44 & 46.4 & 42 \\
\hline Coast & 39 & 37 & 39 & 35 \\
\hline Streams & 19.1 & 18 & 17.6 & 16 \\
\hline Pumping wells & 0 & 0 & 7.6 & 7 \\
\hline Total & 104.1 & & 110.6 & \\
\hline
\end{tabular}

\section{Groundwater Flow Models}

The development and calibration of the groundwater models for the Plymouth-Carver region and western and eastern Cape Cod are fully documented in Masterson and others (2009), Walter and Whealan (2005), and Walter and Masterson (2011). The steady-state and transient versions of the Plymouth-Carver model were used in this study without additional modification. In contrast, a sequence of steady-state and transient models covering Cape Cod were developed for previous investigations (Walter and Whealan, 2005; Walter and Masterson, 2011), and updates to these models were required for the transient analysis (appendix 1). Detailed descriptions of the spatial discretization and layering of the models, hydrologic boundaries, hydraulic properties of the aquifers, hydrologic stresses, observation data used to calibrate the models, and the steady-state and transient calibration procedures and results are provided in the original documentation. Descriptions of the simulation of streams, ponds, and water use (withdrawals and wastewater return flows) pertinent to this study are provided in this section.

In both models, streams were simulated by using the Streamflow-Routing (STR) package for the USGS three-dimensional finite-difference groundwater model MODFLOW (Prudic, 1989); the STR package allows for groundwater discharge to the stream (gaining streams) as well as infiltration from the stream into the aquifer (losing streams) to be modeled. Representing streams by using the STR package allows for simulation of potential losing conditions, particularly downgradient of pond outlets and near production wells. In the STR package, each stream is represented by segment and reach values. A segment is 
Simulated Responses of Streams and Ponds to Groundwater Withdrawals and Wastewater Return Flows in Mass.

a group of stream-reach cells, and a reach is an individual model cell that represents a portion of a stream. For clarity, a reach is referred to as a stream model cell for the rest of the report. In the model, the streams are divided into segments that are numbered from 1, located in the upland area, to the total number of segments located in the lowland area. Each segment consists of two or more stream model cells that are numbered from 1 at the upstream end to the total number of cells at the downstream end. Stream segment and reach information is also included in the shapefiles and spreadsheet files in appendixes 2 and 3 so that simulated changes in flow along a particular stream can be identified; simulations provide streamflow changes for each stream model cell. Streams in the study area generally show gaining characteristics (where streamflow increased with distance downstream). However, in some locations, streams show losing characteristics (where streamflow decreased with distance downstream). Losing characteristics are typically associated with pond outlets or local areas affected by large groundwater withdrawals.

A total of 45, 13, and 3 named streams were simulated in the Plymouth-Carver, western Cape, and eastern Cape models, respectively. Additionally, several unnamed streams were simulated in each model. In total, streamflow was simulated for 3548, 442, and 178 stream model cells in the PlymouthCarver, western Cape, and eastern Cape models, respectively. Some streams of greater length were simulated by using several segments. The total number of ponds simulated was 391, of which 218, 101, and 72 were in the Plymouth-Carver, western Cape, and eastern Cape models, respectively. These included ponds with inflowing or outflowing streams as well as kettle ponds that were not directly connected to streams. Ponds were represented in the groundwater models as areas of high hydraulic conductivity (Masterson and others, 2009; Walter and Whealan, 2005; Walter and Masterson, 2011). There were many instances where a simulated stream received outflow from a headwater pond. That is, once water in the pond (surface water that originated as groundwater that seeped into the pond from the underlying sediments) reached a certain elevation, water flowed out of the pond and into the stream.

Although there are many locations in southeastern Massachusetts where a stream receives outflow from a pond, some locations, such as the Silver Lake/Jones River system in the Plymouth-Carver model (fig. 2), involve water withdrawals and transfers and are more complex than most other pond and stream systems. In the original study, the water withdrawals and transfers at this location were represented in a simplified manner as a surface-water withdrawal from Silver Lake. In addition, simulations were conducted with an approximate pond outlet elevation based on a topographic map. This simplified representation of the Silver Lake/Jones River system in the Plymouth-Carver model was reasonable given the regional nature of the original study. However, for the study detailed in this report, in which determination of streamflow alteration downstream from the pond is a stated objective, the simplified approach used in the regional model to represent the Silver Lake/Jones River system produces uncertainty in the simulation results. This issue is discussed in greater detail in the "Limitations" section of this report.

The locations and rates used in this study for pumping and wastewater return flow are the same as those used in the original studies of Masterson and others (2009) and Walter and Whealan (2005). Steady-state simulations were used to evaluate long-term average effects of pumping and wastewater return flows on water levels and streamflows, and transient simulations were used to evaluate average monthly effects. The current pumping and wastewater return flow conditions were defined as 2000 through 2005 for the Plymouth-Carver model (referred to as 2005 in this report) and 2003 for the western and eastern Cape Cod models. Although these time periods do not exactly coincide, the difference was considered minor and was deemed acceptable for this study.

Production wells, which are represented by a specifiedflux boundary condition, were simulated by the Well (WEL) package of MODFLOW (McDonald and Harbaugh, 1988). In the Plymouth-Carver region, production wells represented in the model were mostly for public supply, but several permitted commercial and irrigation wells were also simulated. Eighty-eight wells from communities in the area were represented in the Plymouth-Carver model (fig. 2; Masterson and others, 2009, table 1-4b); of these wells, 28 were inactive (nonpumping) in 2005. Average monthly pumping rates ranged from 0.01 to 1.16 million gallons per day (Mgal/d). Commercial, irrigation, and private (domestic) well withdrawals represented only a small percentage of the total pumping in the study area, and most of these smaller withdrawals were not represented in the Plymouth-Carver model. For 2005 conditions, the combined pumping from these nonmunicipal sources accounted for less than 10 percent of the total withdrawals (Masterson and others, 2009). In addition, water withdrawn from these wells typically is returned to the aquifer as increased recharge at or near the well; consequently, the net withdrawal of water is near zero. In the western and eastern Cape Cod models, production wells represented in the models also were mostly for public supply (Walter and Whealan, 2005, table 1-3). In 2003, communities in the modeled area operated 184 production wells, of which 117 were in the western Cape and 67 were in the eastern Cape (fig. 3); of these wells, 30 were inactive in 2003. Falmouth also withdrew drinking water directly from Long Pond, the only direct surface-water withdrawal in the Cape Cod models. Average pumping rates ranged from about 0.001 to $2.5 \mathrm{Mgal} / \mathrm{d}$ in 2003 (Walter and Whealan, 2005, table 1-3). As with the Plymouth-Carver model, smaller nonmunicipal withdrawals accounted for only a small proportion of total withdrawals and were not represented in the Cape Cod models. Withdrawals from surface water were represented as a simulated production well located within the area of the pond. For both studies, pumping rates were compiled from Massachusetts Department of Environmental Protection records.

In addition to recharge from precipitation, the portion of water pumped for public supply that is returned to the aquifer through domestic septic systems and centralized 
wastewater treatment facilities is a source of recharge to the aquifer systems in southeastern Massachusetts. Most of the groundwater withdrawn for public supply is returned to the aquifer as wastewater return flow. The consumptive loss rate in residential areas was assumed to be about 15 percent of total pumping; thus, 85 percent of the total public supply was assumed to be returned to the aquifer as enhanced recharge (by means of the Recharge package of MODFLOW; McDonald and Harbaugh, 1988) in residential areas. In southeastern Massachusetts, residential areas are served by varying combinations of water-supply distribution and wastewater disposal systems. Examples include areas with public water supply and septic systems, areas with both public water supply and sewers, and areas with both private water supply (domestic wells) and septic systems. Wastewater return flows associated with public supply withdrawals (the first two combinations) are represented in the groundwater flow models; these return flows represent a net import of water to a residential area. Distributions of septic systems and locations of municipal treatment facilities used for wastewater disposal in the Plymouth-Carver and Cape Cod models are shown in figures 2 and 3, respectively. The nonsewered residential areas, where water from public supply withdrawals is returned to the aquifer through onsite septic systems, are widespread in southeastern Massachusetts (figs. 2 and 3) and represent areas with relatively low rates of enhanced recharge. In the area of the Plymouth-Carver model, there were four centralized wastewater treatment facilities in operation during 2005, in Kingston, Plymouth (2 sites), and Wareham (fig. 2). In the areas of the Cape Cod models, there were five centralized wastewater treatment facilities, in Barnstable, Chatham, Falmouth, Orleans, and on the Massachusetts Military Reservation (fig. 3). These facilities are relatively large point sources of wastewater return flow. Wastewater disposal rates were compiled from data provided by treatment facilities. Overall, for 2005 average conditions, about 3 percent of groundwater discharge to streams in the Plymouth-Carver model area is from wastewater return flow to the aquifer. Wastewater return flow as an additional source of aquifer recharge can have locally important effects on alteration of streamflow and pond water levels (see "Simulated Responses of Streamflows and Pond Levels to Pumping and Wastewater Return Flows" section).

Cranberry bog operations are prevalent in the PlymouthCarver region and less common on Cape Cod. They encompass about $16 \mathrm{mi}^{2}$ (10,000 acres), or about 6 percent of the total active Plymouth-Carver model area. The 2005 annual average water use for the bog operations was about $80 \mathrm{Mgal} / \mathrm{d}$ (James McLaughlin, Massachusetts Department of Environmental Protection, written commun., 2006). However, unlike water pumped for public supply, most of this water originates from the localized manipulation of streamflow in surface-water bodies, such as the diversion and impoundment of streamflow, rather than from the pumping and exporting of water for use away from the pumping source. Groundwater is typically pumped for cranberry irrigation adjacent to the bog areas, where the wells capture water that otherwise would have discharged naturally to the bogs. Therefore, for the purpose of the regional Plymouth-Carver model analysis it was assumed that the water use related to cranberry bog operations was accounted for in the simulated recharge rate. The simulated recharge rate for cranberry bogs was similar to that of wetlands; however, it was assumed that the bogs behave more like ponds than wetlands during the month of October when the bogs are typically flooded for harvesting, resulting in an additional $2 \mathrm{in} / \mathrm{yr}$ of recharge. Therefore, the simulated recharge rate for cranberry bogs was $10 \mathrm{in} / \mathrm{yr}$ compared with the $8 \mathrm{in} / \mathrm{yr}$ specified for wetlands (Masterson and others, 2009). The determination of site-specific cranberry bog irrigation effects on individual streams and ponds would have required detailed local-scale analyses of the water-use operations for individual bogs and thus was not considered in the regional Plymouth-Carver model analysis.

\section{Development of Contributing Areas}

The procedure used in this study to determine contributing areas (including groundwater subbasins and hydrologic units) was based on a procedure documented in Barlow (1997) for delineating contributing areas for production wells on Cape Cod, which was subsequently used by Masterson and others (1998) and Masterson and Walter (2000) for similar analyses. The analysis of Masterson and Walter (2000) also included the delineation of groundwater contributing areas to other discharge locations, such as ponds, streams, and coastal areas. To determine contributing areas, the MODPATH particle-tracking model developed by Pollock (1994), which uses the heads and intercell flow rates (the flow rate at the face of each cell in the model) calculated by the MODFLOW-2000 (Harbaugh and others, 2000) or MODFLOW-2005 (Harbaugh, 2005) flow models, was used to determine water particle pathlines and velocities. Starting locations of particles must be specified to initiate a particletracking analysis. Particles may be tracked either forward (from the water table to a discharge location) or backward (from a discharge location to the water table), but forward tracking has proven to be more reliable for delineating contributing areas (Barlow, 1997). Masterson and others (1998) used MODPATH to track particles forward through the simulated flow system until they reached the locations of production wells (discharge areas). In Masterson and others (1998), the contributing area to the selected well was defined by the area at the water table from which the particles that were captured by the well originated. Pollock (1994), Barlow (1997), Franke and others (1998), Masterson and others (1998), and Masterson and Walter (2000) provide detailed information on the use of particle tracking for the delineation of areas contributing groundwater to discharge locations.

In this study, the steady-state models of the PlymouthCarver region and western and eastern Cape Cod were used to track particles forward, from the water table to the discharge 
Simulated Responses of Streams and Ponds to Groundwater Withdrawals and Wastewater Return Flows in Mass.

location, in the direction of groundwater flow. In the MODPATH simulations, a single instantaneous release was specified of a two-dimensional four-by-four array of particles that were placed at the top face in each grid cell in the model, and endpoints were recorded for the particles that terminated in a specific zone. "Zone" is a term used by MODPATH that in this analysis refers to the stream subsections or lengths along streams between outlet points. Ponds were included in these subsections if they were connected to a stream at its headwaters (for example, Halfway Pond and Little Herring Pond [fig. 2] in the Plymouth-Carver model) or if they were directly connected to the stream and therefore considered to be part of the stream network (for example, Glen Charlie Pond and Great Herring Pond [fig. 2] in the Plymouth-Carver model). In the MODPATH analysis, all the stream cells and surfacewater-connected pond cells in a zone between outlet points were assigned the same identification number to determine the groundwater contributing area to that stream subsection. Ponds not in direct surface-water contact with a stream were not included in a respective zone. The groundwater contributing areas delineated in this study are those expected to occur under steady-state, predevelopment conditions.

Groundwater contributing areas were calculated to evaluate streamflow depletion at the outlets of groundwater subbasins and determine selected landscape characteristics within groundwater subbasins (see the following discussion of subbasins and hydrologic units). Determination of streamflow alteration and landscape characteristics at the subbasin scale provides information comparable to that in Weiskel and others (2010). Although the methods used in this study to delineate contributing areas to streams differed from those described in Weiskel and others (2010), the same terminology was used for consistency (fig. 4). A subbasin is defined as the total upstream drainage area (or watershed) that drains to a selected location along a stream (referred to as an outlet point in this report); if there are multiple outlet points selected along a stream, the contributing area of the uppermost outlet point is referred to as a headwater subbasin. A hydrologic unit is defined as the local area that drains to a stream between two outlet points. For the upstreammost outlet point on streams with multiple points and for streams with a single outlet point, hydrologic units and subbasins are coincident (fig. 4).

This analysis produced 78 contributing areas in southeastern Massachusetts (figs. 5 through 7; tables 3 and 4). Of the 78 hydrologic units in the study area (fig. 5), 61 are also headwater subbasins (fig. 6). Although differentiated in figures 6 and 7 to more clearly show the extent of each subbasin, several headwater subbasins are nested within larger subbasins that correspond to downstream outlet points (fig. 7). For example, hydrologic units HU-78 and HU-79 (fig. 5) are combined to form subbasin SB-79 (fig. 7). The remaining 17 hydrologic units on the large streams compose the local drainage areas to outlet points downstream from the headwater areas. Precipitation that falls on the land surface outside of hydrologic unit and subbasin areas ultimately discharges directly to the coast; these areas are extensive in southeastern Massachusetts (figs. 5 through 7).

Table 3. Stream identification, landscape characteristics, and simulated average streamflows for hydrologic units and subbasins in southeastern Massachusetts.

[Available separately at http://dx.doi.org/10.3133/sir20155168]

Table 4. Percent impervious cover and long-term average streamflow for hydrologic units in southeastern Massachusetts.

[Available separately at http://dx.doi.org/10.3133/sir20155168]

The outlet points were positioned to provide hydrologic units of similar size to the topographically determined areas in Weiskel and others (2010), which averaged $5.3 \mathrm{mi}^{2}$. Based on an average recharge rate of $27 \mathrm{in} / \mathrm{yr}$ (Walter and Whealan, 2005; Masterson and others, 2009) applied to the 400-by-400-foot (ft) model cells over a $5.3-\mathrm{mi}^{2}$ area, an increase in simulated streamflow of about 10.4 cubic feet per second $\left(\mathrm{ft}^{3} / \mathrm{s}\right)$ was used to identify the length of the stream subsection between outlet points that corresponded to the contributing area of $5.3 \mathrm{mi}^{2}$. This streamflow criterion was used as a general guideline to divide simulated streams with various numbers of tributaries into subsections so that locations of outlet points could be identified. Simulated long-term average streamflows at the downstream ends of the subsections (or the outlet points of the hydrologic units) ranged from 0 to $17.3 \mathrm{ft}^{3} / \mathrm{s}$ (tables 3 and 4). Most of the streamflows at the lower end of this range were in shorter streams that drained small contributing areas (for example, hydrologic unit HU-24 and subbasin SB-24; figs. 5 and 6; tables 3 and 4). The streamflow of $0 \mathrm{ft}^{3} / \mathrm{s}$ was in subbasin SB-23, which is discussed in greater detail in the "Alteration of Streamflows at Subbasin Outlets" section of this report. Most of the streamflows at the higher end of this range were associated with long streams that drained large contributing areas with relatively extensive stream networks that included multiple tributaries. Multiple outlet points were used to delineate hydrologic units on these streams (for example, subbasin SB-8, which consisted of hydrologic units HU-2, HU-3, HU-4, HU-5, HU-6, HU-7, and HU-8; fig. 7; tables 3 and 4). One of the various exceptions to the simple accumulation of streamflow from groundwater contributing areas is the Billington Sea/Town Brook system (fig. 2), which was represented in the Plymouth-Carver model by a headwater pond with a single outflow stream (hydrologic unit HU-32 and subbasin SB-32). The simulated long-term average predevelopment outflow from Billington Sea to Town Brook was $12.4 \mathrm{ft}^{3} / \mathrm{s}$ (already greater than the streamflow criterion of $10.4 \mathrm{ft}^{3} / \mathrm{s}$ ), and the streamflow at the outlet point of Town Brook was $17.3 \mathrm{ft}^{3} / \mathrm{s}$. This example shows the effect that pond outflows can have on simulated streamflows. 
A. Hydrologic Units (HU)

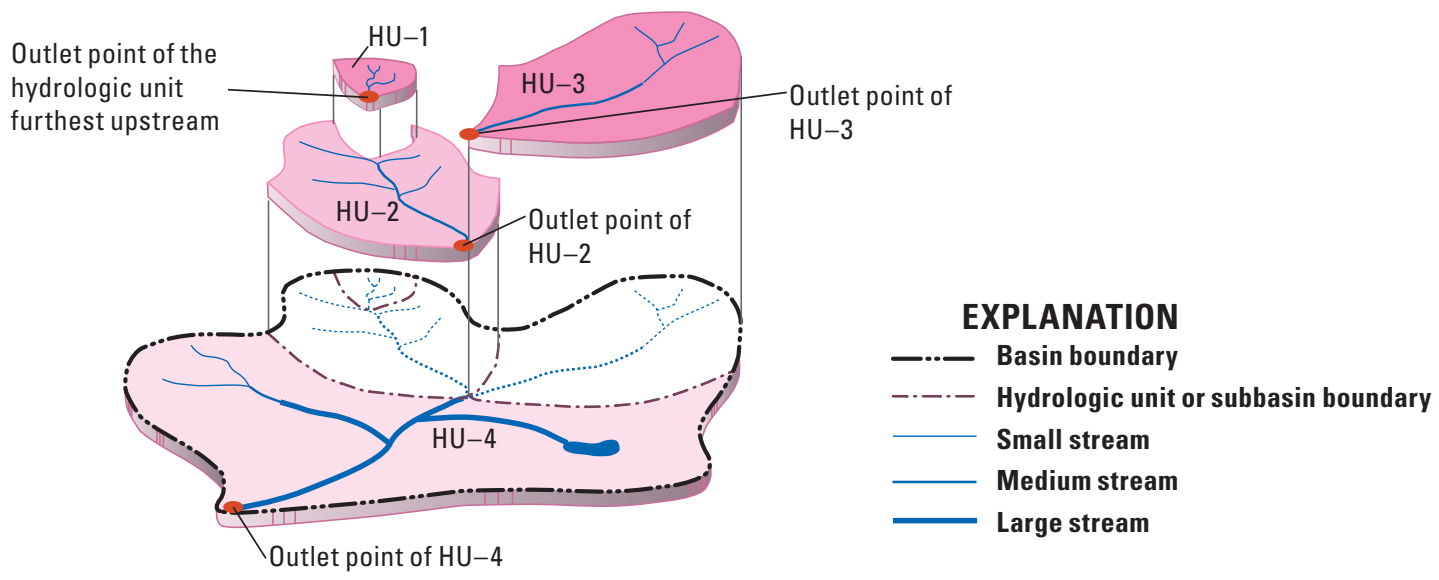

B. Nested or "stacked" subbasins (SB)

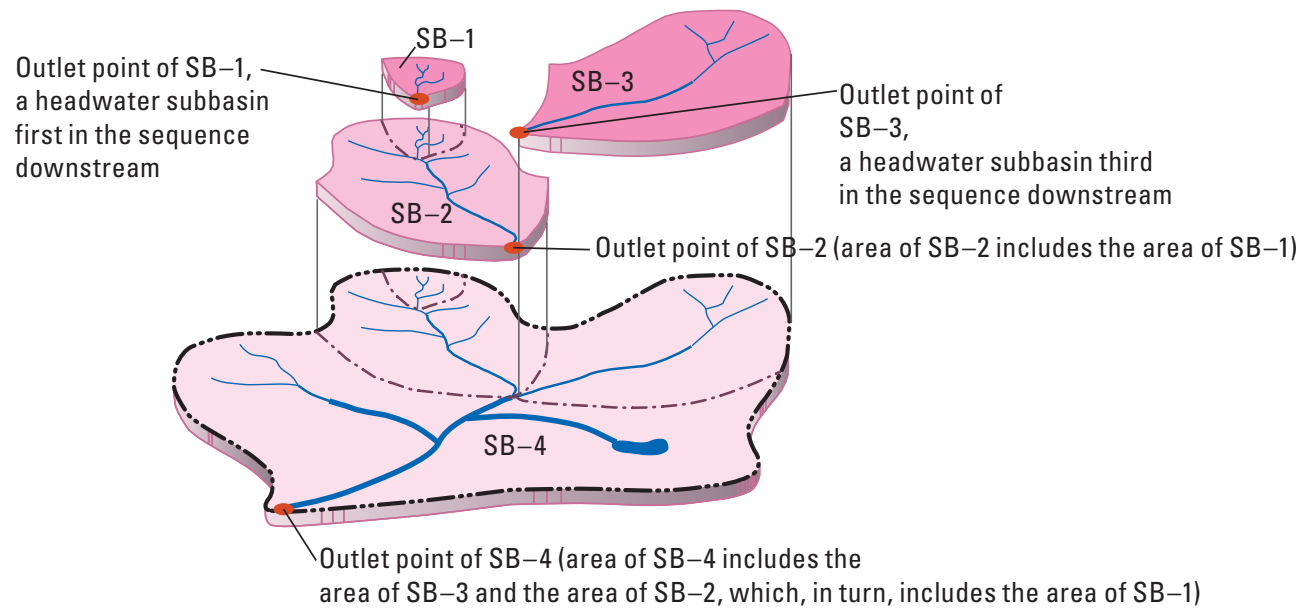

Figure 4. Generalized groundwater contributing areas in southeastern Massachusetts defined as $A$, hydrologic units and $B$, subbasins for simulating responses of streams and ponds to groundwater withdrawals and wastewater return flows. A hydrologic unit is defined as the local area that drains to a particular stream or set of small streams between two outlet points. A subbasin is defined as the entire upstream area that drains to an outlet point; the area of subbasins increases in the downstream direction. Hydrologic units of southeastern Massachusetts are shown in figure 5; headwater subbasins are shown in figure 6, and other subbasins are shown in figure 7. Modified from Weiskel and others (2010). 


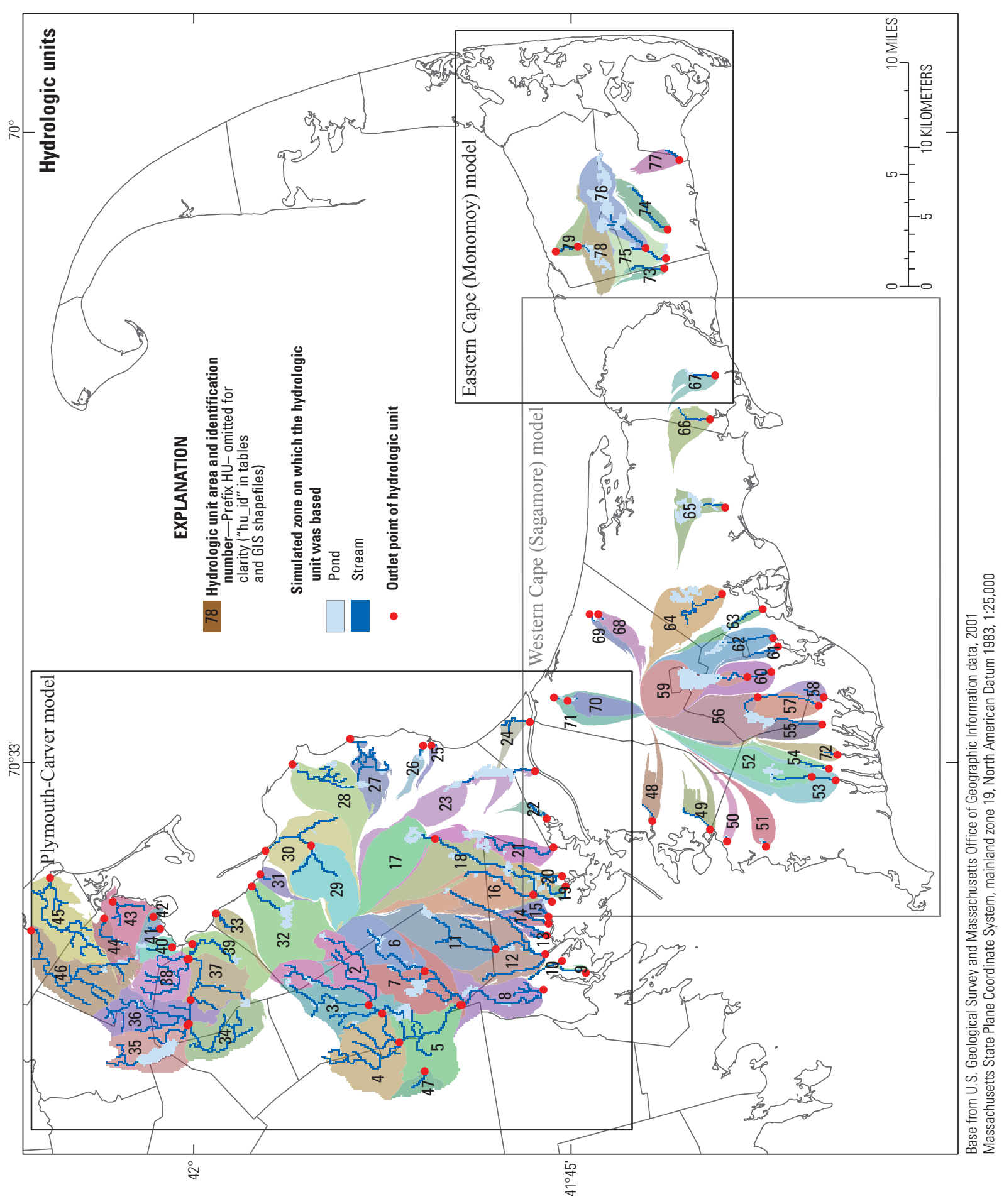

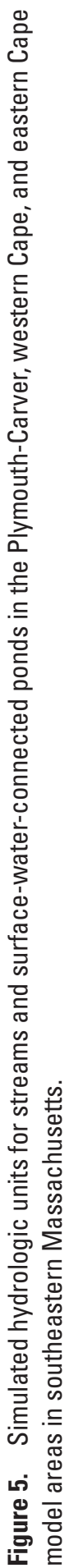




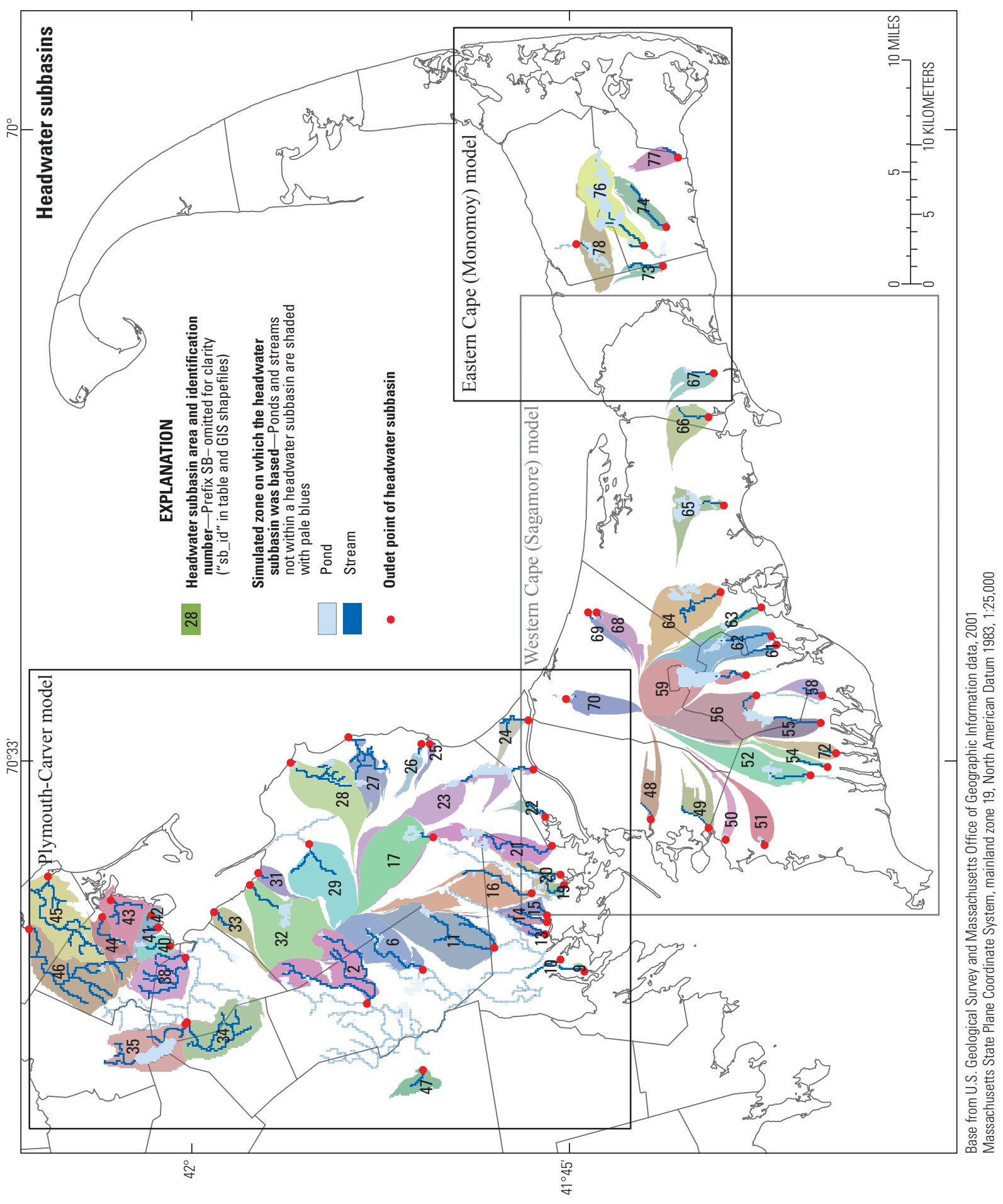

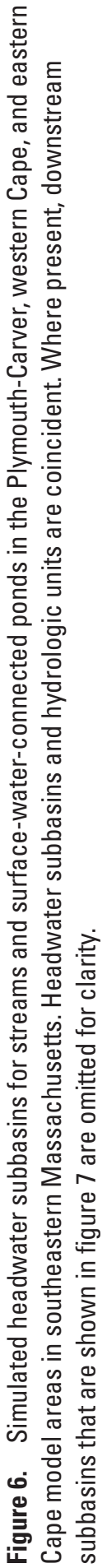



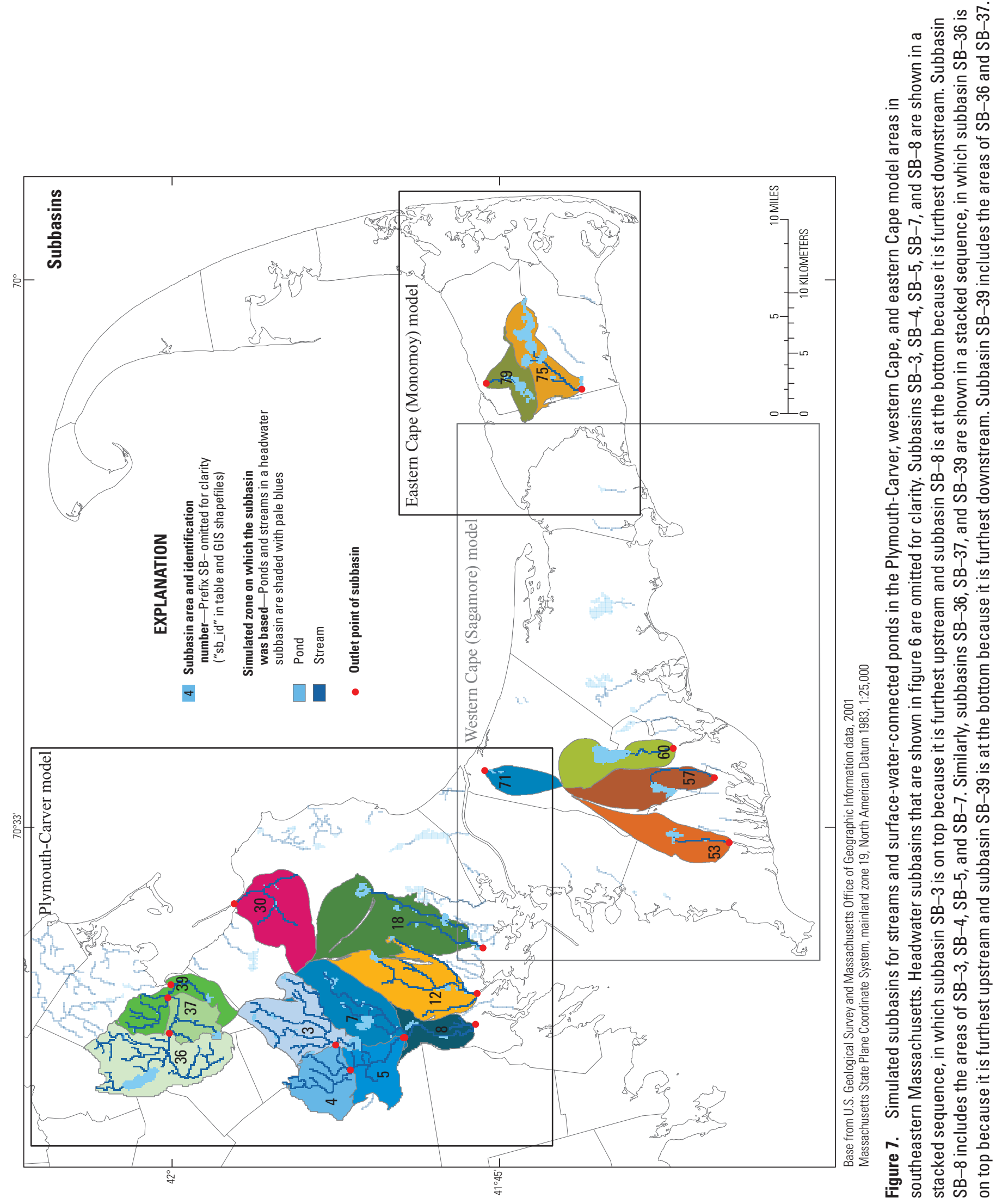


\section{Simulated Responses of Streamflows and Pond Levels to Pumping and Wastewater Return Flows}

The simulated responses of streamflows and pond levels to pumping and wastewater return flows varied by location and included no change in areas minimally affected by water use, decreases in areas affected more by pumping than by wastewater return flows, or increases in areas affected more by wastewater return flows than by pumping. Groundwater models were used to simulate these responses because the models simultaneously accounted for the simulated locations of streams, ponds, production wells, and return flows, the spatial variability of hydraulic properties of the aquifer both vertically by model layer and horizontally, the long-term average and the average monthly recharge rates to the aquifer, and pumping and wastewater return flow rates. Uncertainties inherent in using groundwater models to address complex groundwater/surface-water interactions are described in the "Limitations" section of this report.

To identify which stream cells and pond locations could be affected under pumping only and pumping with wastewater return flow conditions, changes in simulated streamflows and pond levels were determined by subtracting the simulated results of each water use condition from the predevelopment condition. Simulated streamflows and changes in streamflow of less than $0.1 \mathrm{ft}^{3} / \mathrm{s}$ were considered to be negligible and within the margin of model error. Therefore, results shown in the shapefiles and spreadsheet tables and described below reflect streamflows and changes in streamflows of $0.1 \mathrm{ft}^{3} / \mathrm{s}$ or greater. Changes in streamflows of less than $0.1 \mathrm{ft}^{3} / \mathrm{s}$ were set equal to zero in these files. In addition to calculating absolute changes, streamflow alterations were also calculated as percentages to more clearly show the relative effects of pumping and wastewater return flows on streamflow. For example, streamflow in a stream cell in Indian Brook in Plymouth (fig. 2) was $0.5 \mathrm{ft}^{3} / \mathrm{s}$ under predevelopment conditions and decreased $0.5 \mathrm{ft}^{3} / \mathrm{s}$ under pumping only conditions, which corresponds to a decrease of 100 percent (stream cell went dry), whereas streamflow in a stream cell in the Weweantic River (fig. 2) was $28.7 \mathrm{ft}^{3} / \mathrm{s}$ under predevelopment conditions and decreased by $1.1 \mathrm{ft}^{3} / \mathrm{s}$ under pumping only conditions, which corresponds to a decrease of only 4 percent, even though the absolute magnitude of streamflow depletion in the Weweantic River was greater than in Indian Brook.

For the transient analysis of streamflow and pond-level alterations under average monthly conditions, simulated changes for August are highlighted in the report as an example of monthly results. Weiskel and others (2010) found that the greatest degree of monthly streamflow alteration occurred in August, and Armstrong and others (2011) used the percent alteration of August median streamflows in their analysis of the effects of withdrawals on fish assemblages. Simulation results for all streams and ponds for all months and for longterm average conditions are contained in appendix 2 .
Streams in southeastern Massachusetts are relatively small compared with those in the rest of the Commonwealth. Maximum long-term average predevelopment streamflows ranged from $13.1 \mathrm{ft}^{3} / \mathrm{s}$ in the eastern Cape model to $68.8 \mathrm{ft}^{3} / \mathrm{s}$ in the Plymouth-Carver model (table 5).

\section{Alteration of Streamflows at Subbasin Outlets}

For consistency with Weiskel and others (2010), streamflow alterations were computed at the outlets of the groundwater subbasins. Long-term average (steady-state) and average monthly conditions are detailed in this section.

\section{Long-Term Average Conditions}

Streamflow results are summarized in the following sections for long-term average (steady-state) simulations for predevelopment, pumping only, and pumping with wastewater return flow conditions for southeastern Massachusetts at the outlet point of each subbasin (fig. 8). To compare results among subbasins, steady-state streamflows from each subbasin were also normalized by subbasin area to yield absolute streamflows in cubic feet per second per square mile $\left(\mathrm{ft}^{3} / \mathrm{s} / \mathrm{mi}^{2}\right)$ (fig. 9). The relative difference in streamflows due to pumping only and pumping with wastewater return flow conditions in comparison to predevelopment conditions at each subbasin is also shown.

\section{Predevelopment Conditions}

The medians and averages of normalized predevelopment streamflows at subbasin outlets, respectively, were 1.6 cubic feet per second per square mile $\left(\mathrm{ft}^{3} / \mathrm{s} / \mathrm{mi}^{2}\right)$ and $1.6 \mathrm{ft}^{3} / \mathrm{s} / \mathrm{mi}^{2}$ for the Plymouth-Carver model, 1.8 and $1.7 \mathrm{ft}^{3} / \mathrm{s} / \mathrm{mi}^{2}$ for the western Cape model, and 1.8 and $1.6 \mathrm{ft}^{3} / \mathrm{s} / \mathrm{mi}^{2}$ for the eastern Cape model. The medians and averages of the nonnormalized streamflows were 7.8 and $6.9 \mathrm{ft}^{3} / \mathrm{s}$ for the Plymouth-Carver model, 4.2 and $4.9 \mathrm{ft}^{3} / \mathrm{s}$ for the western Cape model, and 3.8 and $4.3 \mathrm{ft}^{3} / \mathrm{s}$ for the eastern Cape model. The Plymouth-Carver region tended to have streams of longer length than streams on Cape Cod. For most of the subbasins shown in figure 9, simulated streamflows normalized by subbasin area were about $2 \mathrm{ft}^{3} / \mathrm{s} / \mathrm{mi}^{2}$ or less. However, normalized streamflows in subbasin SB-19 (unnamed tributary to Muddy Cove, Plymouth-Carver model) were about $4.3 \mathrm{ft}^{3} / \mathrm{s} / \mathrm{mi}^{2}$. The larger normalized streamflows likely are due to the complicated hydrology in the headwater area of subbasin SB-19 where it borders subbasin SB-20 (Gibbs Brook in the Plymouth-Carver model). The local-scale complexities of the groundwater/surface-water interactions in this area may not be well represented at the scale of the regional model, and thus the simulated streamflows and ultimately the resulting area for subbasin SB-19 may not be well represented by results of the regional model, leading to an anomalously high normalized streamflow. The implications of local effects within a regional groundwater model are discussed in greater detail in the "Limitations" section of this report. 
Table 5. Summary of maximum simulated streamflows and the percentages of stream cells with streamflows within specific ranges under predevelopment conditions for long-term average and monthly simulations of the Plymouth-Carver, western Cape, and eastern Cape models in southeastern Massachusetts.

$\left[\mathrm{ft}^{3} / \mathrm{s}\right.$, cubic foot per second; $>$, greater than; $<$, less than; $\geq$, greater than or equal to]

\begin{tabular}{|c|c|c|c|c|c|c|c|c|}
\hline $\begin{array}{c}\text { Simulation } \\
\text { period }\end{array}$ & $\begin{array}{l}\text { Maximum pre- } \\
\text { development } \\
\text { streamflow in } \\
\text { a stream cell, } \\
\text { in } \mathrm{ft}^{3} / \mathrm{s}\end{array}$ & $\begin{array}{l}\text { Percentage of } \\
\text { stream cells } \\
\text { that were dry } \\
\text { (no simulated } \\
\text { flow in the cell) }\end{array}$ & $\begin{array}{c}\text { Percentage } \\
\text { of stream } \\
\text { cells where } \\
\text { flow was }>0 \\
\text { but }<0.1 \mathrm{ft}^{3} / \mathrm{s}\end{array}$ & $\begin{array}{c}\text { Percentage of } \\
\text { stream cells } \\
\text { where flow } \\
\text { was } \geq 0.1 \mathrm{ft}^{3} / \mathrm{s} \\
\text { but }<1.0 \mathrm{ft}^{3} / \mathrm{s}\end{array}$ & $\begin{array}{c}\text { Percentage of } \\
\text { stream cells } \\
\text { where flow } \\
\text { was } \geq 1.0 \mathrm{ft}^{3} / \mathrm{s} \\
\text { but }<5.0 \mathrm{ft}^{3} / \mathrm{s}\end{array}$ & $\begin{array}{c}\text { Percentage of } \\
\text { stream cells } \\
\text { where flow } \\
\text { was } \geq 5.0 \mathrm{ft}^{3} / \mathrm{s} \\
\text { but }<20.0 \mathrm{ft}^{3} / \mathrm{s}\end{array}$ & $\begin{array}{c}\text { Percentage of } \\
\text { stream cells } \\
\text { where flow } \\
\text { was } \geq 20.0 \mathrm{ft}^{3} / \mathrm{s} \\
\text { but }<40.0 \mathrm{ft}^{3} / \mathrm{s}\end{array}$ & $\begin{array}{l}\text { Percentage } \\
\text { of stream } \\
\text { cells where } \\
\text { flow was } \\
\geq 40.0 \mathrm{ft}^{3} / \mathrm{s}\end{array}$ \\
\hline \multicolumn{9}{|c|}{ Plymouth-Carver model } \\
\hline January & 78.1 & 17 & 3 & 24 & 26 & 19 & 6 & 5 \\
\hline February & 82.1 & 17 & 3 & 23 & 26 & 20 & 6 & 5 \\
\hline March & 87.4 & 16 & 3 & 23 & 26 & 20 & 6 & 6 \\
\hline April & 84.8 & 16 & 3 & 23 & 27 & 20 & 6 & 5 \\
\hline May & 77.4 & 17 & 3 & 24 & 26 & 19 & 6 & 5 \\
\hline June & 67.7 & 17 & 5 & 25 & 26 & 18 & 6 & 3 \\
\hline July & 54.6 & 19 & 5 & 26 & 25 & 18 & 5 & 2 \\
\hline August & 50.3 & 20 & 6 & 25 & 24 & 18 & 5 & 2 \\
\hline September & 50.6 & 20 & 5 & 26 & 24 & 18 & 5 & 2 \\
\hline October & 51.7 & 21 & 5 & 25 & 24 & 18 & 5 & 2 \\
\hline November & 62.9 & 20 & 4 & 24 & 25 & 18 & 6 & 3 \\
\hline December & 73.6 & 18 & 4 & 24 & 25 & 19 & 5 & 5 \\
\hline Steady state & 68.8 & 18 & 4 & 25 & 25 & 18 & 6 & 4 \\
\hline \multicolumn{9}{|c|}{ Western Cape model } \\
\hline January & 18.8 & 10 & 2 & 21 & 36 & 31 & 0 & 0 \\
\hline February & 20.2 & 8 & 2 & 20 & 37 & 32 & 0 & 0 \\
\hline March & 21.7 & 7 & 1 & 19 & 39 & 33 & 1 & 0 \\
\hline April & 22.6 & 6 & 1 & 19 & 39 & 33 & 2 & 0 \\
\hline May & 21.4 & 6 & 2 & 19 & 40 & 33 & 1 & 0 \\
\hline June & 19.4 & 6 & 3 & 19 & 41 & 31 & 0 & 0 \\
\hline July & 17.0 & 7 & 2 & 25 & 38 & 27 & 0 & 0 \\
\hline August & 16.0 & 9 & 5 & 26 & 34 & 25 & 0 & 0 \\
\hline September & 15.4 & 12 & 3 & 31 & 31 & 23 & 0 & 0 \\
\hline October & 15.5 & 12 & 4 & 28 & 32 & 24 & 0 & 0 \\
\hline November & 16.0 & 12 & 3 & 23 & 35 & 26 & 0 & 0 \\
\hline December & 17.2 & 12 & 3 & 22 & 35 & 29 & 0 & 0 \\
\hline Steady state & 18.4 & 8 & 2 & 21 & 38 & 30 & 0 & 0 \\
\hline \multicolumn{9}{|c|}{ Eastern Cape model } \\
\hline January & 13.7 & 17 & 1 & 19 & 34 & 29 & 0 & 0 \\
\hline February & 14.6 & 17 & 1 & 14 & 39 & 29 & 0 & 0 \\
\hline March & 15.6 & 16 & 1 & 12 & 41 & 30 & 0 & 0 \\
\hline April & 15.9 & 16 & 1 & 12 & 40 & 31 & 0 & 0 \\
\hline May & 14.8 & 17 & 1 & 12 & 40 & 30 & 0 & 0 \\
\hline June & 12.9 & 18 & 1 & 12 & 43 & 26 & 0 & 0 \\
\hline July & 9.9 & 18 & 1 & 28 & 38 & 16 & 0 & 0 \\
\hline August & 8.3 & 20 & 2 & 35 & 30 & 13 & 0 & 0 \\
\hline September & 8.0 & 22 & 7 & 28 & 30 & 13 & 0 & 0 \\
\hline October & 8.7 & 22 & 3 & 31 & 28 & 15 & 0 & 0 \\
\hline November & 11.0 & 21 & 6 & 26 & 20 & 26 & 0 & 0 \\
\hline December & 12.6 & 17 & 1 & 33 & 20 & 29 & 0 & 0 \\
\hline Steady state & 13.1 & 16 & 1 & 15 & 39 & 29 & 0 & 0 \\
\hline
\end{tabular}




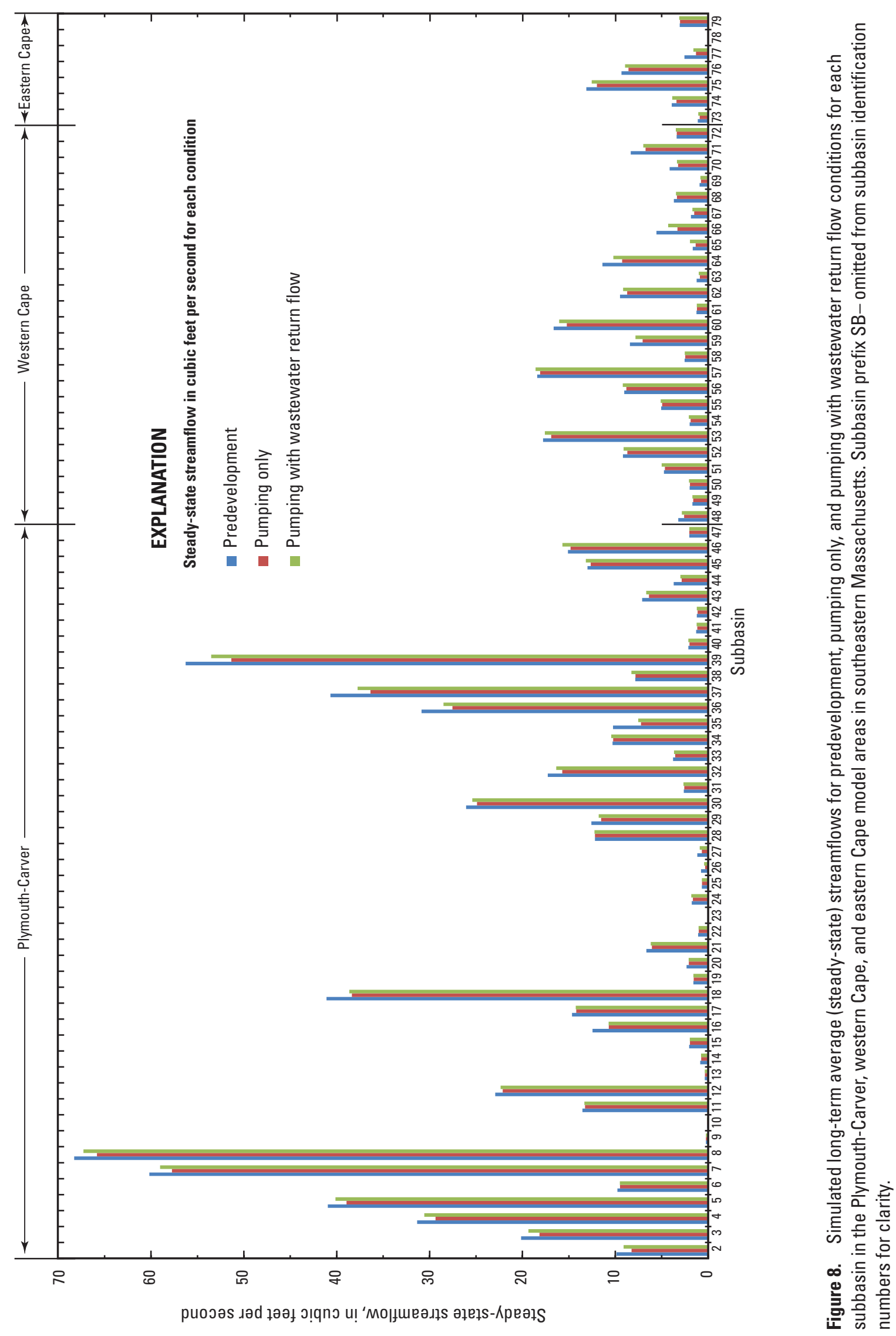




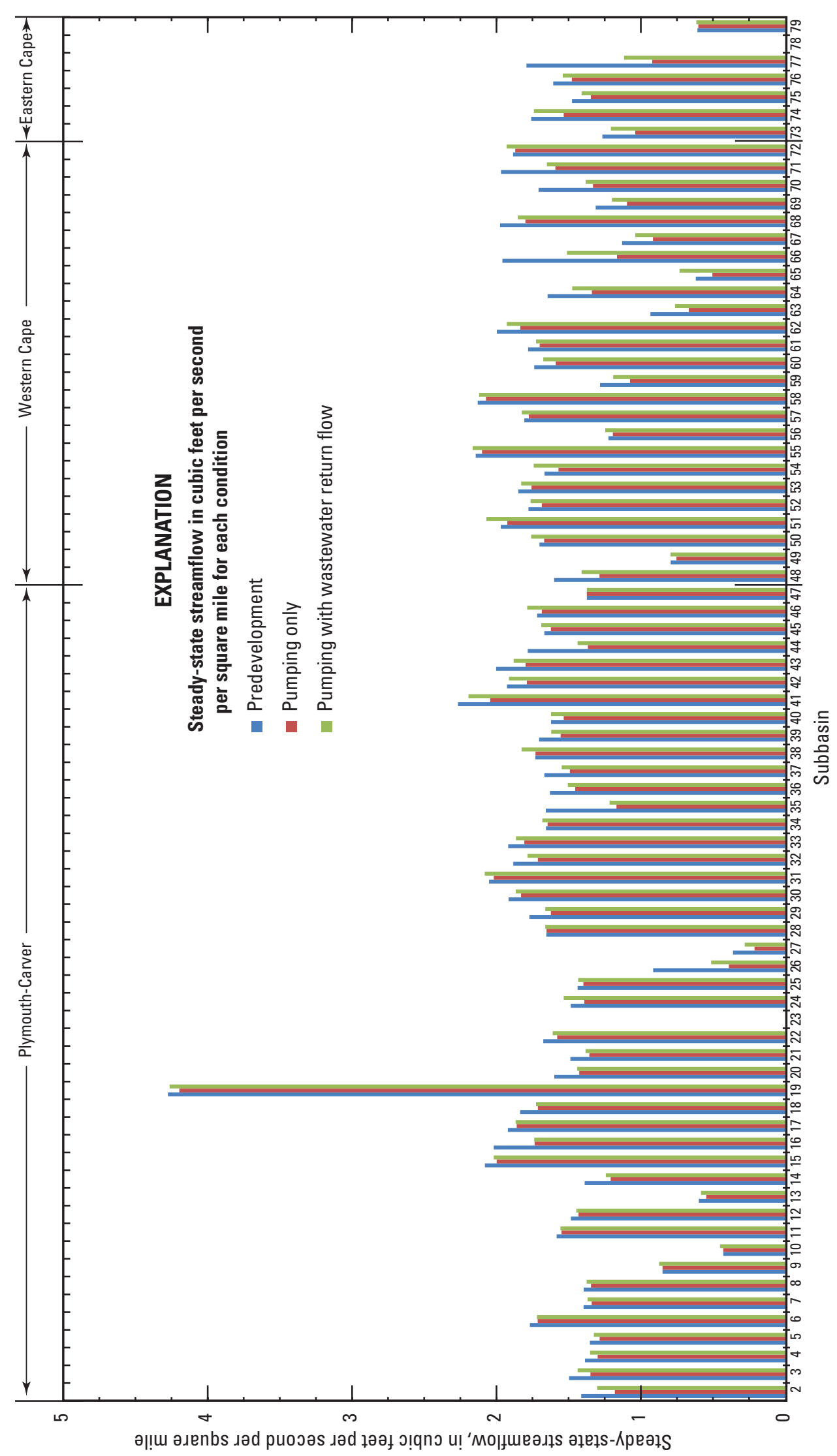

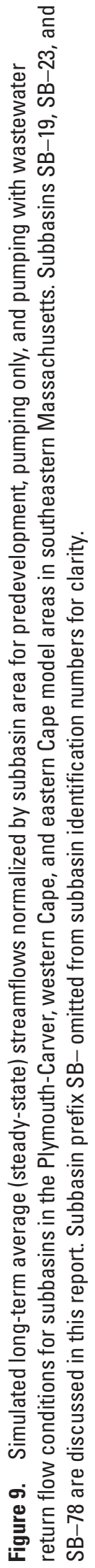




\section{Pumping Only Conditions}

Simulated percentage alterations to long-term average streamflows due to pumping only are shown by subbasin in figure $10 \mathrm{~A}$. The largest depletions by model area were 57.4 percent for subbasin SB-26 (unnamed tributary to Salt Pond, Plymouth-Carver model; fig. 2), 40.5 percent for subbasin SB-66 (Hawes Run, western Cape model; fig. 3), and 48.6 percent for subbasin SB-77 (Red River, eastern Cape model; fig. 3). Median streamflow alterations for the subbasins in the model areas were -5.8 percent for the Plymouth-Carver, -8.2 percent for the western Cape, and -8.8 percent for the eastern Cape model areas.

Streamflows from subbasins SB-23 (Herring River, Plymouth-Carver model) and SB-78 (Stony Brook, eastern Cape model) were dry under predevelopment, pumping only, and pumping with wastewater return flow conditions (fig. 8). Subbasin SB-23 contains Great Herring Pond, which outflows to the Herring River. Under long-term average predevelopment conditions, the upstream end of Herring River receives inflow from the pond outlet at Great Herring Pond, but the simulation results show that flow from Great Herring Pond into the Herring River subsequently infiltrates into the underlying aquifer, resulting in no-flow conditions at the subbasin outlet point at the Cape Cod Canal. The results for subbasins SB-23 and SB-78 may be an artifact of how the change in gradient of the stream is represented at the discretization of the regional model grid.

\section{Pumping With Wastewater Return Flow Conditions}

Simulated alterations to long-term average (steadystate) streamflows in response to pumping with wastewater return flows by subbasin are shown in figure $10 B$. The largest depletions by model area were 43.9 percent for subbasin SB-26 (unnamed tributary to Salt Pond, Plymouth-Carver model), 22.8 percent for subbasin SB-66 (Hawes Run, western Cape model), and 37.7 percent for subbasin SB-77 (Red River, eastern Cape model). The changes in streamflow for subbasins SB-26 and SB-77 were less than $1 \mathrm{ft}^{3} / \mathrm{s}$, but the percentage depletions were higher than in other subbasins because of the relatively low predevelopment streamflow compared with the change in streamflow. In contrast to streamflow decreases in response to pumping only, the return of wastewater to the aquifer as enhanced recharge can offset depletions due to pumping or even increase water levels and streamflows in certain areas. The largest increases (surcharged streamflows) by model area were 5.5 percent for subbasin SB-38 (Halls Brook and Tussock Brook combined, PlymouthCarver model), 18.2 percent for subbasin SB-65 (unnamed tributary to Centerville River, western Cape model), and 1.3 percent for subbasin SB-79 (Stony Brook, eastern Cape model). Increases in streamflows in response to wastewater return flows were generally largest in subbasins with a high density of septic systems or a centralized wastewater treatment facility. Median streamflow alterations for the subbasins in the model areas were -2.7 percent for the Plymouth-Carver,
-3.1 percent for the western Cape, and -4.1 percent for the eastern Cape, and alterations were near median values for most of the subbasins in the study area (for example, alterations at 65 of 78 subbasins were within 10 percent of predevelopment streamflows). As shown in figure 10, streamflow depletions at subbasin outlets were more common than augmentations.

\section{Average Monthly Conditions}

This section describes simulated streamflow results for average monthly conditions. The months of January, April, August, and October were the focus of the study of Weiskel and others (2010); summary results for all months are discussed further in the following sections (tables 5 and 6). Complete simulated streamflows results (all months at all streams in the model areas) are included in appendixes 2 and 3.

To show the effects of water use during August, which is the low-streamflow month evaluated in previous studies, average August streamflows under predevelopment, pumping only, and pumping with wastewater return flow conditions at the outlets of the subbasins are shown in figures 11 and 12 in a format similar to that used for long-term average conditions (figs. 8 and 9). Overall, simulation results show that August streamflows in nearly all subbasins are affected by water use; however, alterations were relatively minor compared with predevelopment streamflows in most locations ("Pumping With Wastewater Return Flow Conditions" section). Similar to long-term average conditions, the relative effects of pumping and return flows in the subbasins with lower streamflows at outlets typically are larger than in the subbasins with higher streamflows. The rates of pumping from the aquifer, the rates of return of wastewater to the aquifer as enhanced recharge, the location of these stresses in relation to streams, and aquifer properties can affect the extent of streamflow alteration.

\section{Predevelopment Conditions}

Maximum streamflows under predevelopment conditions for the Plymouth-Carver region for January, April, August, and October were 78.1, 84.8, 50.3, and $51.7 \mathrm{ft}^{3} / \mathrm{s}$, respectively (table 5). Streamflows generally were lower for the subbasins on Cape Cod because streams are smaller there than in the Plymouth-Carver region. Maximum streamflows under predevelopment conditions for the western Cape for January, April, August, and October were 18.8, 22.6, 16.0, and $15.5 \mathrm{ft}^{3} / \mathrm{s}$, respectively (table 5 ). The lowest maximum monthly streamflow of $15.4 \mathrm{ft}^{3} / \mathrm{s}$ occurred in September. Maximum streamflows under predevelopment conditions for the eastern Cape for January, April, August, and October were 13.7, 15.9, 8.3 , and $8.7 \mathrm{ft}^{3} / \mathrm{s}$, respectively (table 5). The lowest maximum predevelopment streamflow of $8.0 \mathrm{ft}^{3} / \mathrm{s}$ occurred in September. Streamflows tended to be lowest in August, but certain streams showed slightly lower streamflows in other months. 


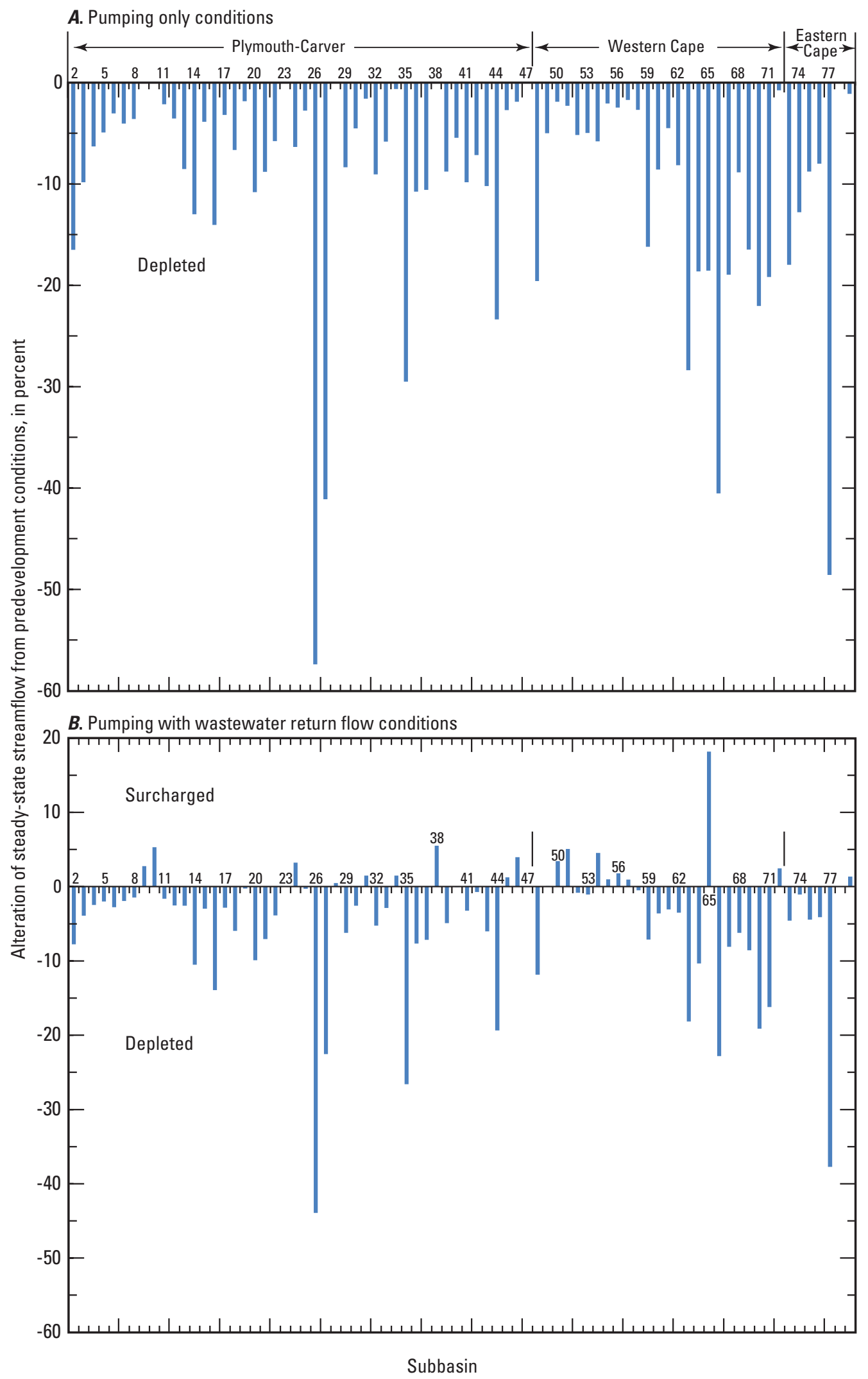

Figure 10. Percentage simulated changes in long-term average streamflow at the outlets of subbasins in southeastern Massachusetts from predevelopment conditions for $A$, pumping only or $B$, pumping with wastewater return flow conditions at the outlet of each subbasin. Prefix SB- omitted from subbasin identification numbers for clarity. 

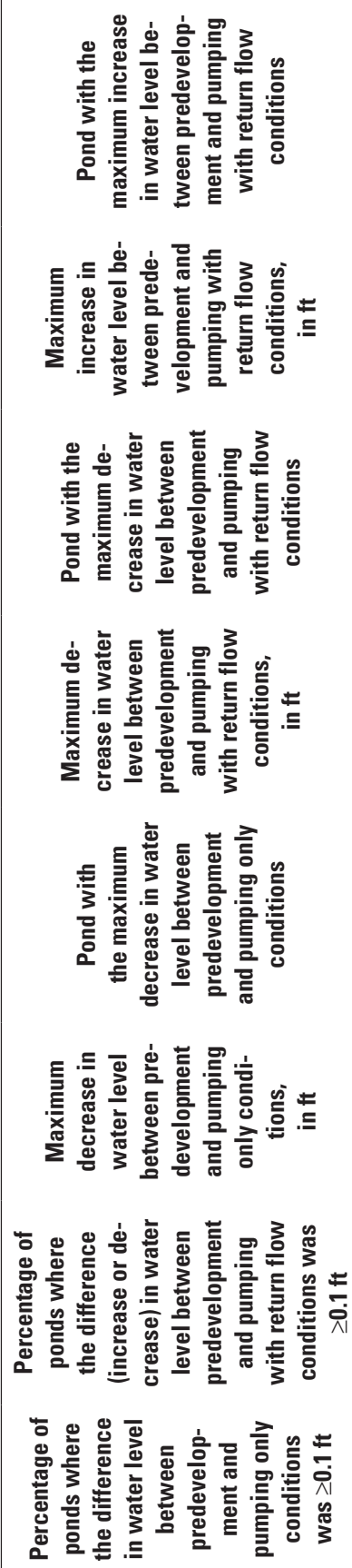

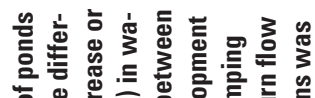

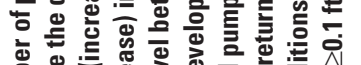

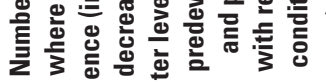

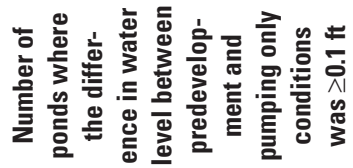

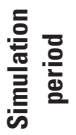

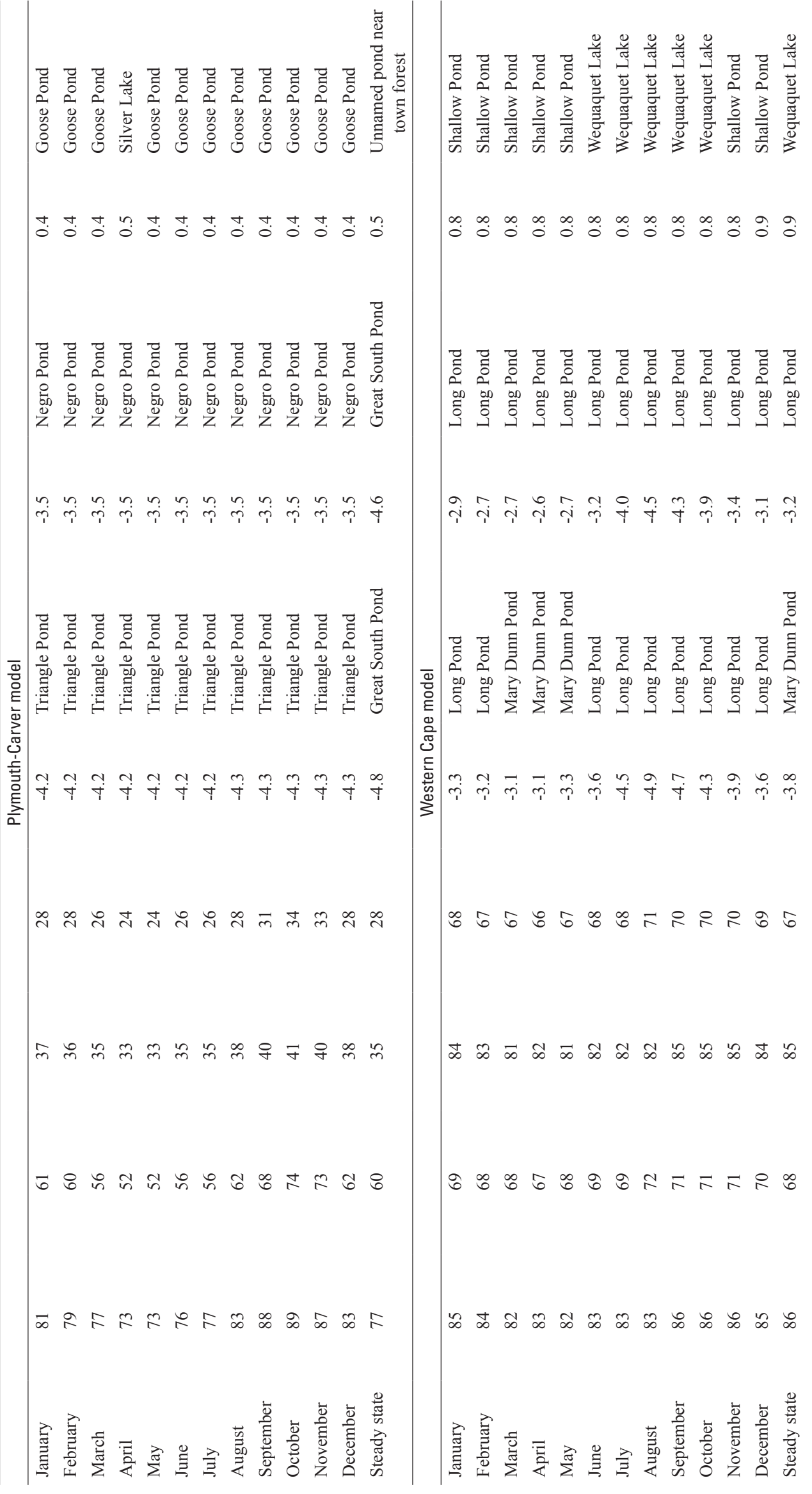




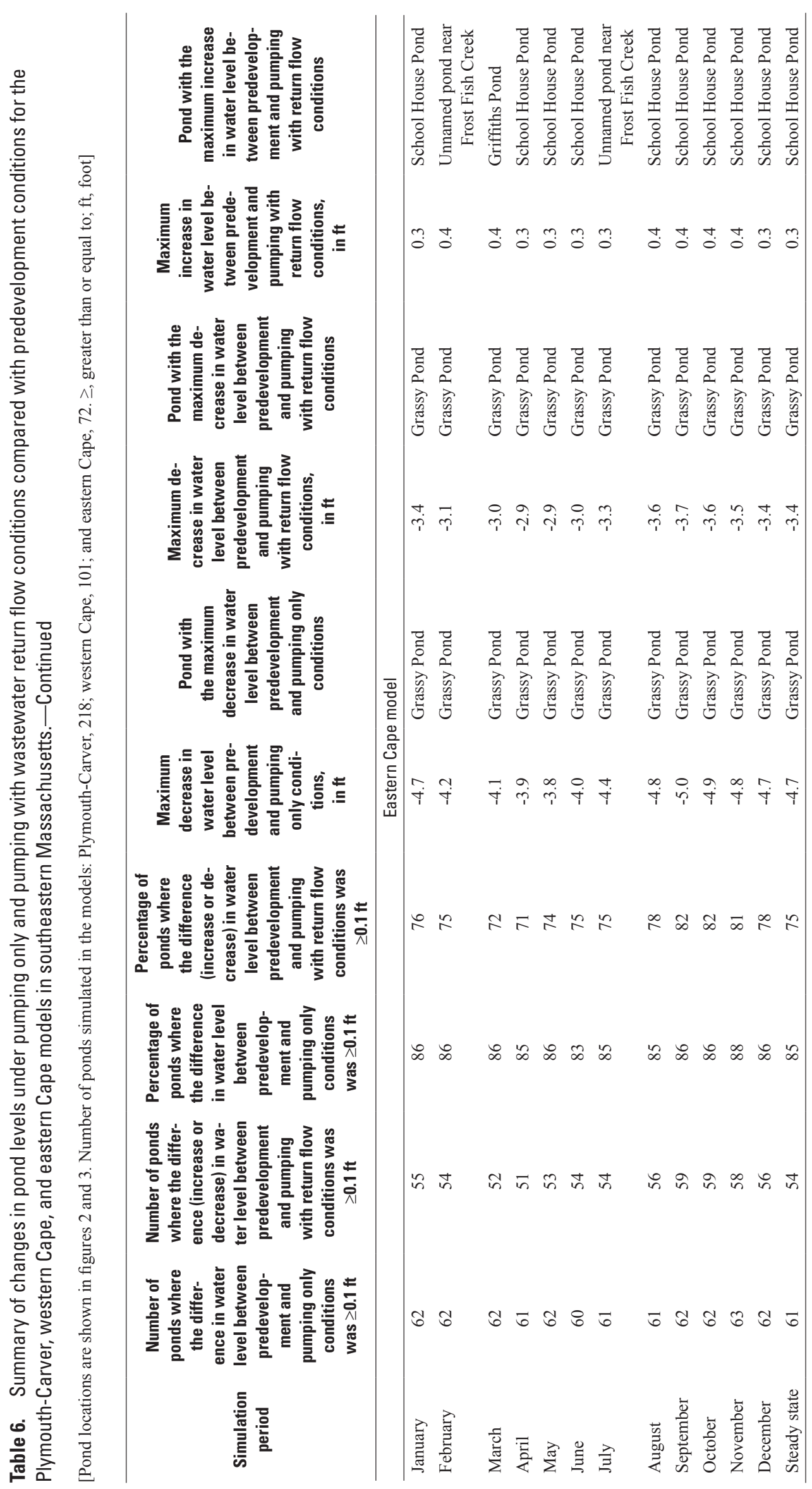




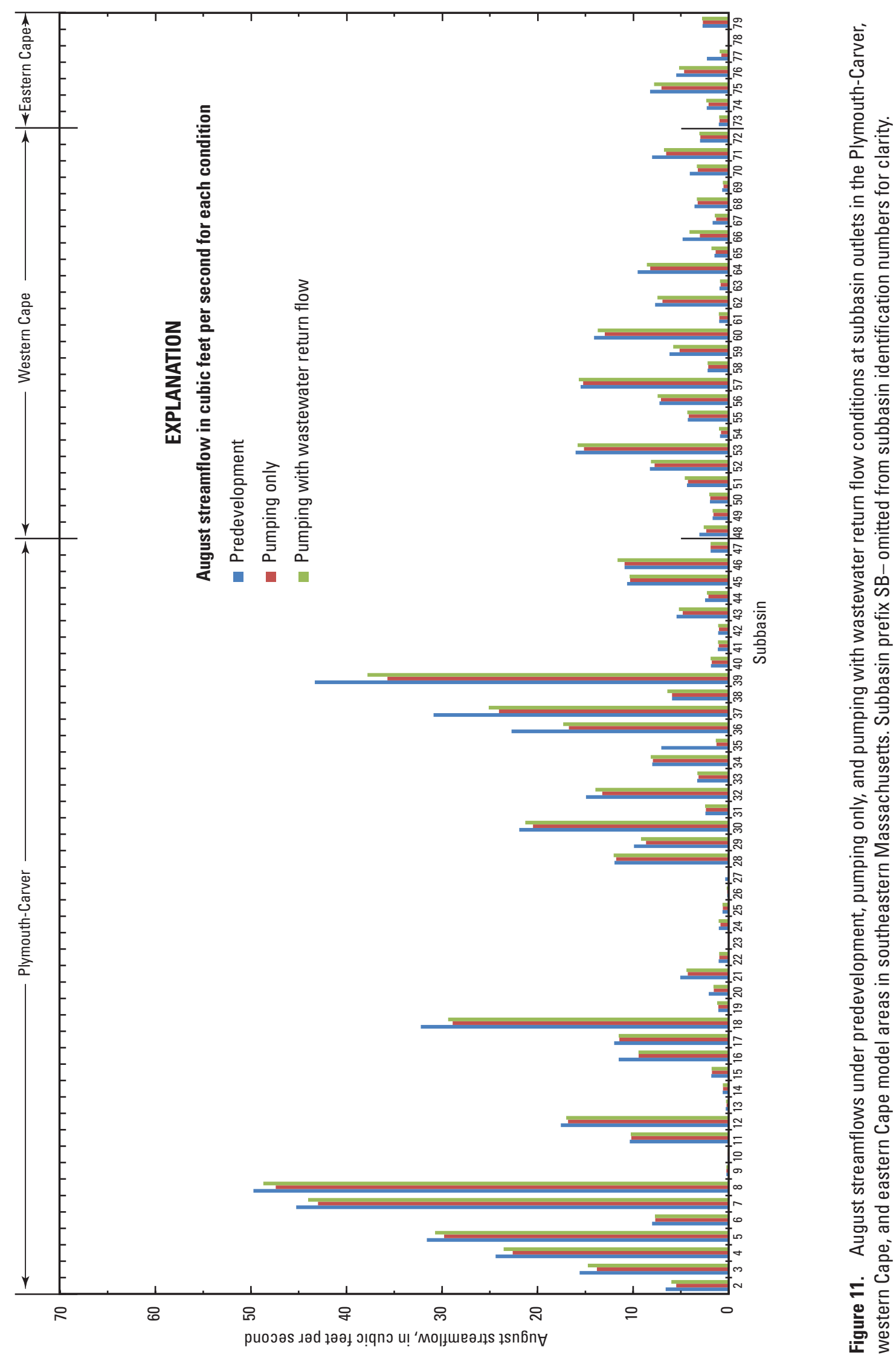




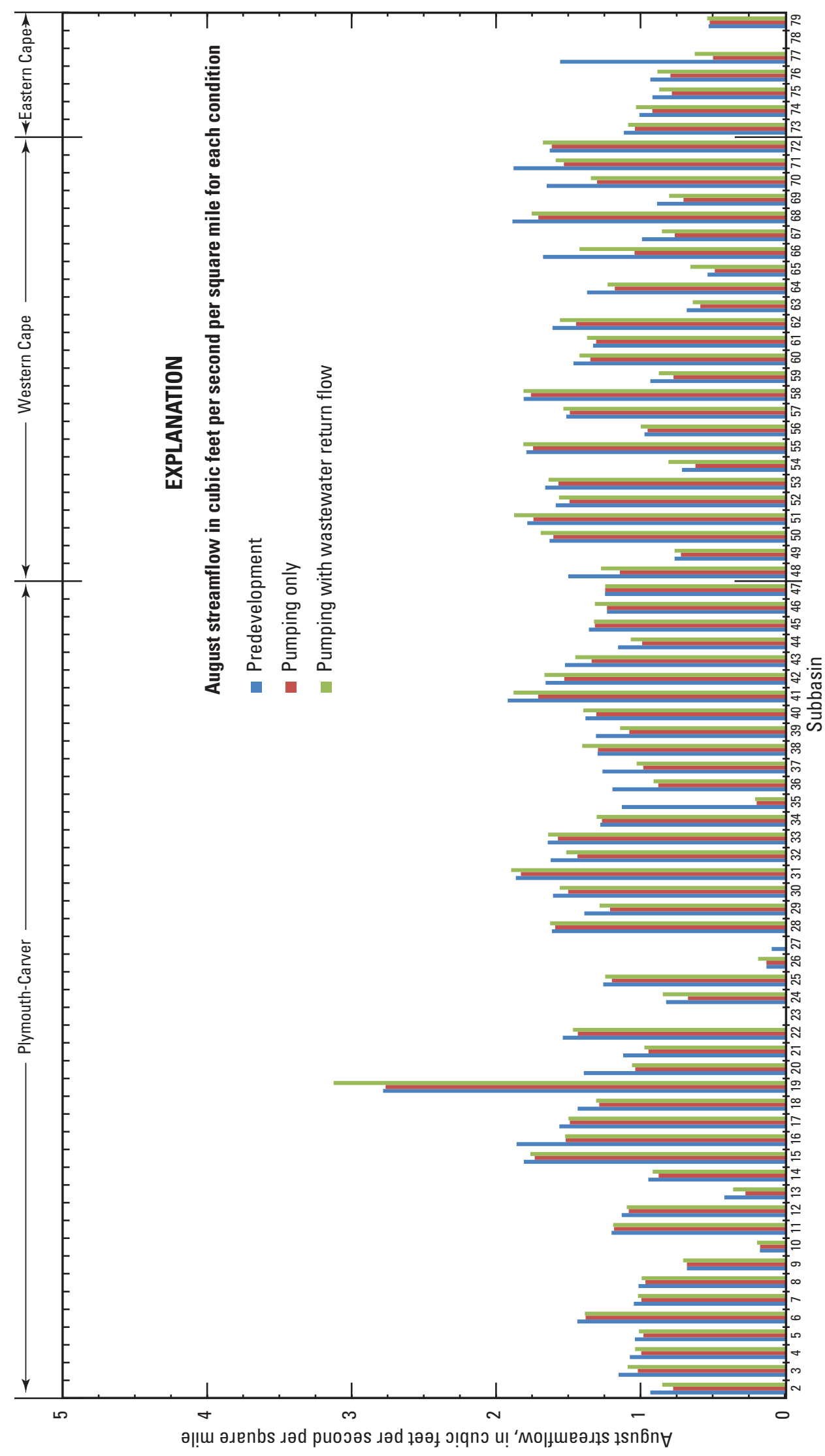

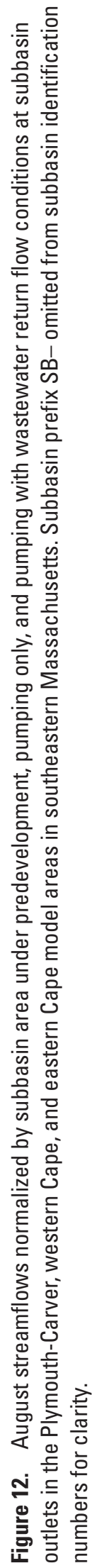




\section{Pumping Only Conditions}

Percentage alterations to average January, April, August, and October streamflows under pumping only conditions are shown by subbasin in figure 13 . These results show that the percentage streamflow decreases in response to pumping generally were largest during the low-streamflow months of August and October. Simulated percentage alterations of average August streamflows are shown in map view for the subbasins in the model areas in figure 14. The greatest simulated depletions by model area for August were 100 percent (the simulated streamflow under pumping only conditions was zero at the outlet point of the subbasin, thus giving the appearance of a large streamflow depletion for the subbasin, when only the last $400 \mathrm{ft}$ at the downstream end of the simulated stream went dry) for subbasin SB-27 (Indian Brook, Plymouth-Carver model), 37.7 percent for subbasin SB-66 (Hawes Run, western Cape model), and 66.9 percent for subbasin SB-77 (Red River, eastern Cape model). The median average August streamflow alteration at subbasin outlets under pumping only conditions by model area was -6.6 percent for the Plymouth-Carver, -9.1 percent for the western Cape, and -8.8 percent for the eastern Cape model areas. Overall, percentage streamflow depletions for pumping only conditions were larger under average August conditions than under long-term average conditions.

The results for subbasins SB-23, SB-27, and SB-78 demonstrate the nuances of using groundwater model output to examine streamflow changes at various scales. Similar to subbasin SB-23 (Herring River) for long-term average conditions, subbasin SB-27 (Indian Brook) was a losing stream under pumping only conditions near the coast. If streamflow in the fourth upstream cell from the downstream end of Indian Brook were used rather than streamflow in the last cell, the depletion for average August conditions would be 69.7 percent rather than 100 percent. In both subbasins, there was streamflow under pumping only conditions in the stream cells immediately upstream of the cells chosen to be the outlet points, but zero streamflow at the outlet points. Similarly, in the last cell in subbasin SB-78, there was no simulated streamflow for most months (results show the cell had streamflow in February, March, and April) under predevelopment conditions, but the cell had no streamflow for all months under pumping only and pumping with wastewater return flow conditions. Because of this, figure 13 indicates a 100 -percent depletion for April and none for the other months.

\section{Pumping With Wastewater Return Flow Conditions}

Monthly simulations under pumping with wastewater return flow conditions showed subbasins with both decreased and increased streamflows compared with predevelopment conditions. A comparison of alterations due to pumping only and pumping with wastewater return flow conditions sorted by values for alteration from pumping with wastewater return flows is shown in figure 15. Increased streamflows indicate that enhanced recharge from wastewater return flows exceeded reductions in streamflow from pumping (if present) for a net increase in streamflow compared with predevelopment conditions. Decreased streamflows indicate that enhanced recharge from wastewater return flows did not exceed reductions in streamflow from pumping, resulting in a net decrease in streamflow compared with predevelopment conditions. The largest simulated depletions by model area for August were 100 percent (went dry) for subbasin SB-27 (Indian Brook, Plymouth-Carver model), 18.5 percent for subbasin SB-70 (Shawme Lake, western Cape model), and 59.7 percent for subbasin SB-77 (Red River, eastern Cape model). The largest surcharged streamflows by model area for August were 43.7 percent for subbasin SB-26 (unnamed tributary to Salt Pond, Plymouth-Carver model), 22.1 percent for subbasin SB-65 (unnamed tributary to Centerville River, western Cape model), and 2.3 percent for subbasin SB-74 (unnamed tributary to Herring River, eastern Cape model). Median August streamflow alterations for pumping with wastewater return flow conditions for the subbasins were -2.9 percent for the Plymouth-Carver, -1.4 percent for the western Cape, and -2.6 percent for the eastern Cape model areas. Alterations of average August streamflows at most subbasin outlets were near median values (for example, 58 of 78 were within 10 percent of predevelopment streamflows). Of the subbasins with simulated surcharged streamflows (fig. 15), 19 subbasins were surcharged up to 10 percent, and 5 were surcharged between 10 and 44 percent.

All the subbasins that showed surcharges for pumping with wastewater return flow conditions showed varying degrees of depletion for pumping only conditions. One example from the Plymouth-Carver model area was subbasin SB-24 (unnamed tributary to Cape Cod Canal in Bourne), with a comparatively low predevelopment August streamflow $\left(0.98 \mathrm{ft}^{3} / \mathrm{s}\right)$, which showed an 18.2 percent depletion for pumping only conditions and a 2.8 percent surcharge for pumping with wastewater return flow conditions (fig. 15). Streamflow in subbasin SB-24 was affected by additional recharge to the aquifer from septic-system return flow in an area of water lines without sewering and two production wells (fig. 2), only one of which was active during 2005. In this subbasin, the amount of increased aquifer recharge was large enough to effect a small surcharge in streamflow compared with the rate of water pumped from the well.

Results for subbasins similar to those shown in figures 13 and 14 for pumping only conditions were compiled for pumping with wastewater return flow conditions (figs. 16 and 17). Figure 16 shows simulated alterations in average January, April, August, and October streamflows under pumping with wastewater return flow conditions in comparison with predevelopment conditions at the outlets of the subbasins. Overall, as with pumping only conditions, results in figure 16 show that percentage streamflow depletions were largest during the low-streamflow months of August and October. Streamflow surcharges were more variable by month but also were largest during the low-streamflow months in most subbasins. Figure 17 shows results for average August 


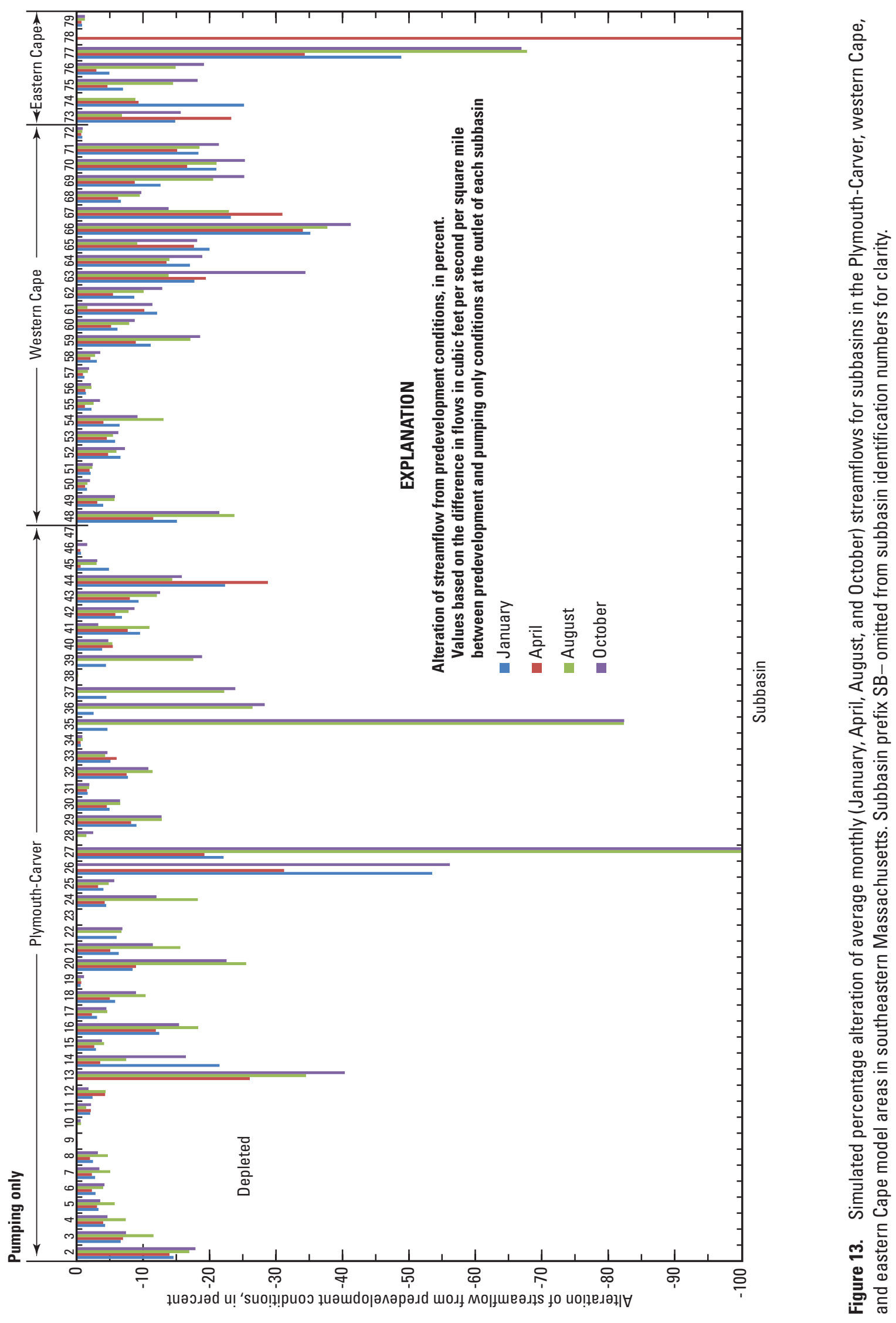




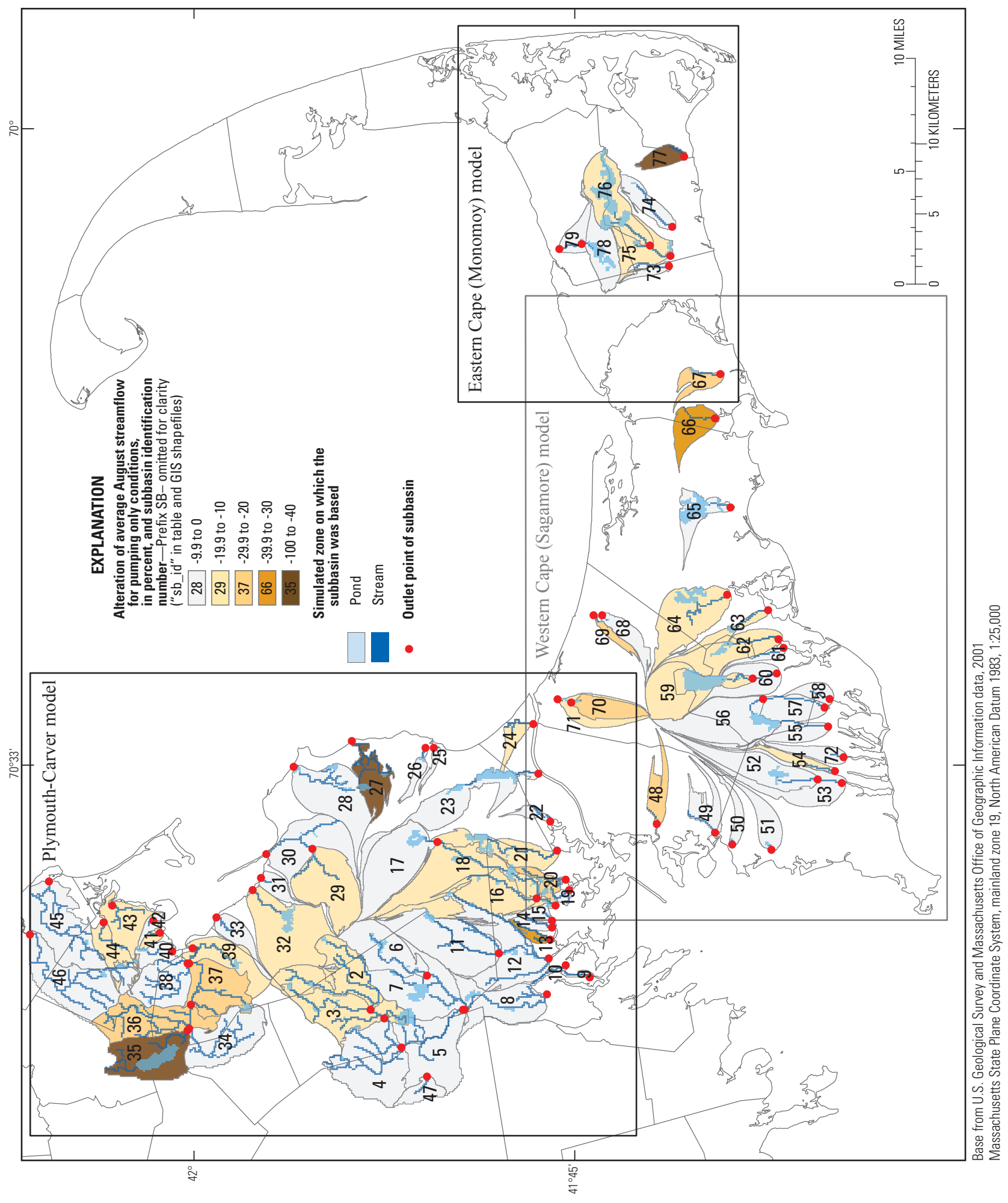

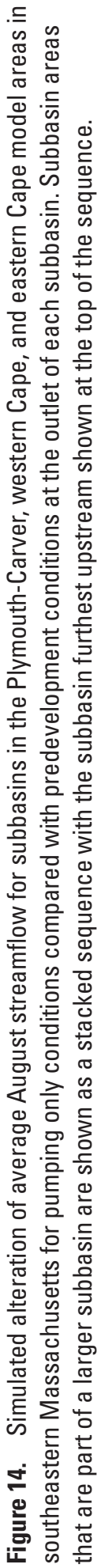



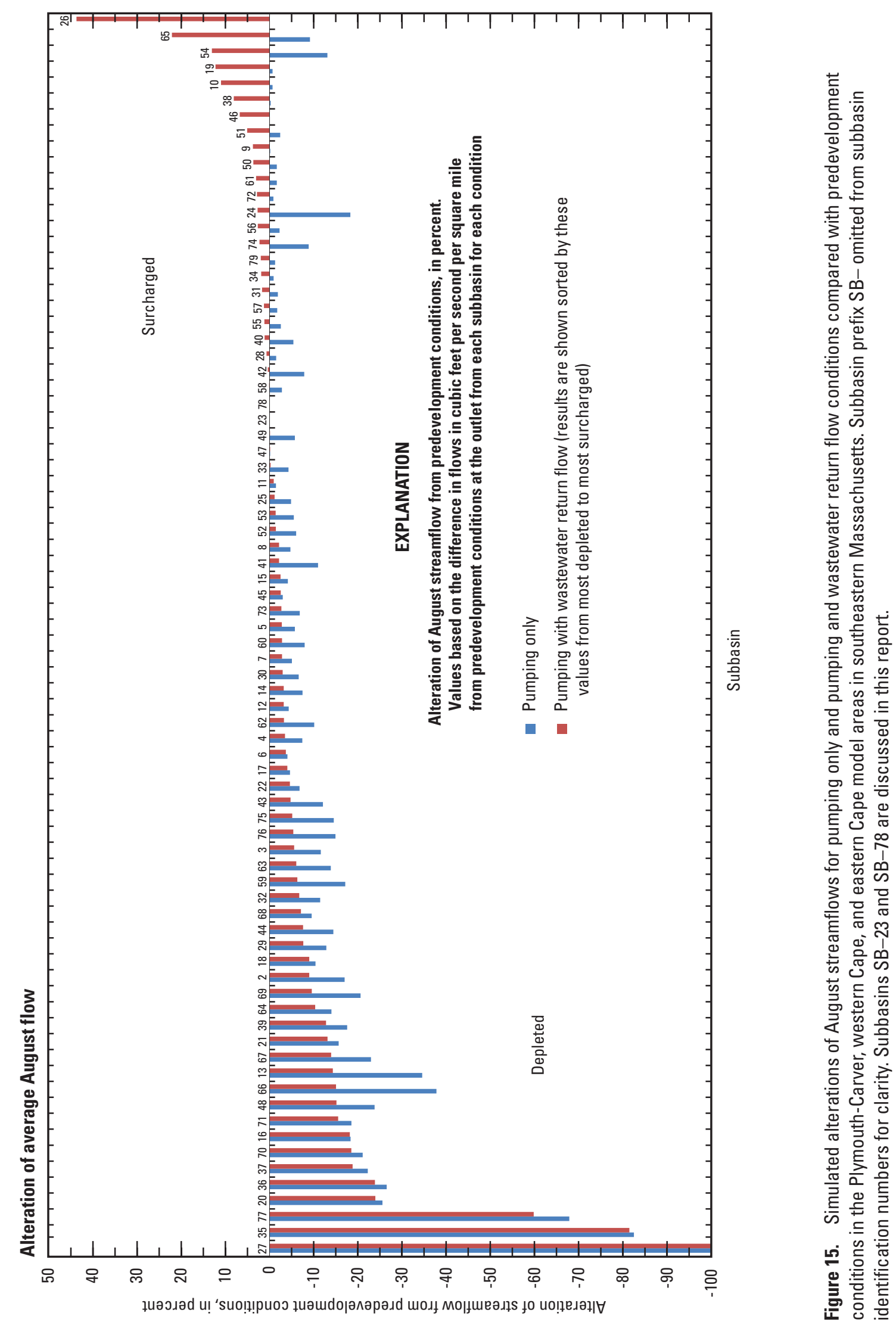

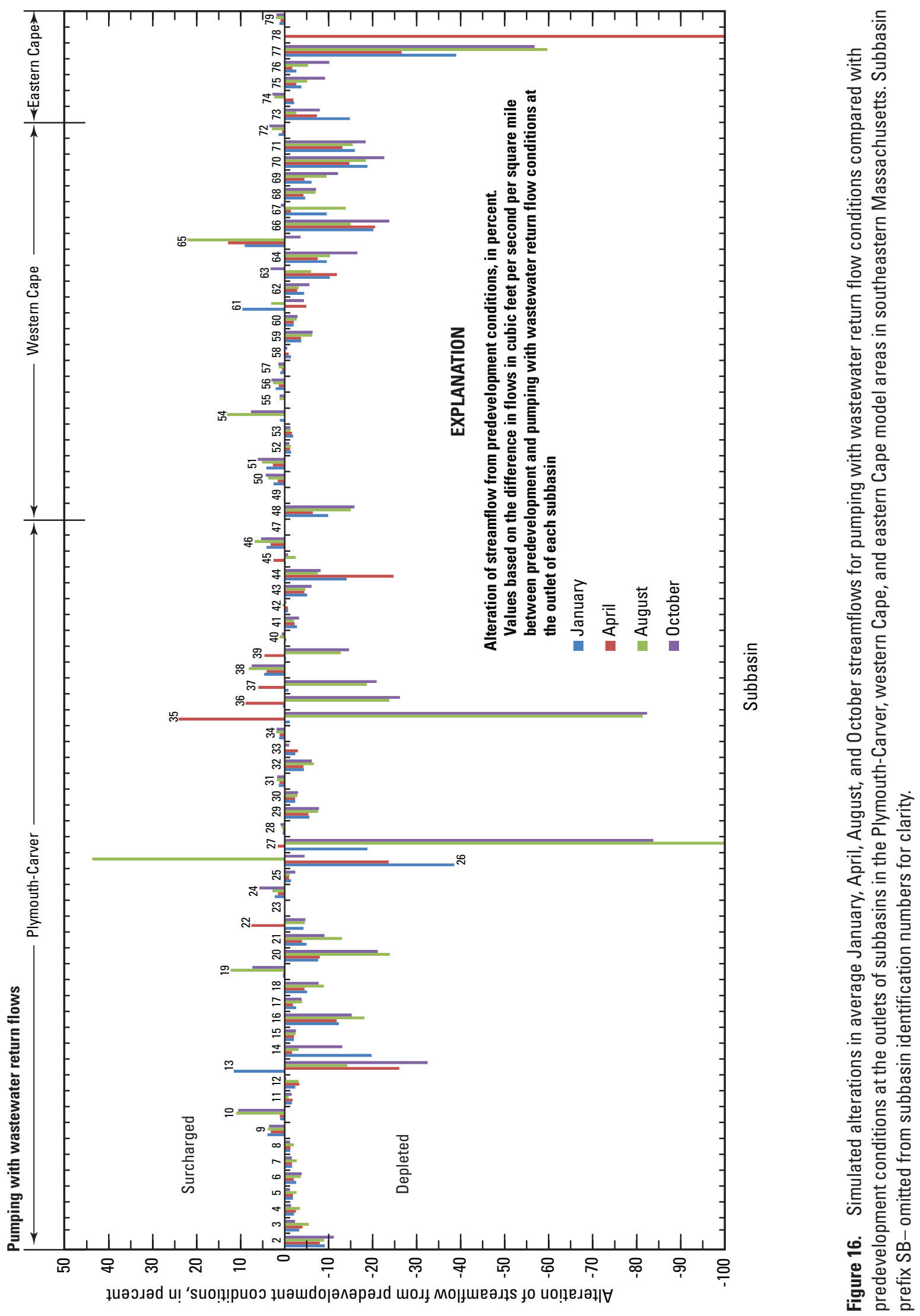


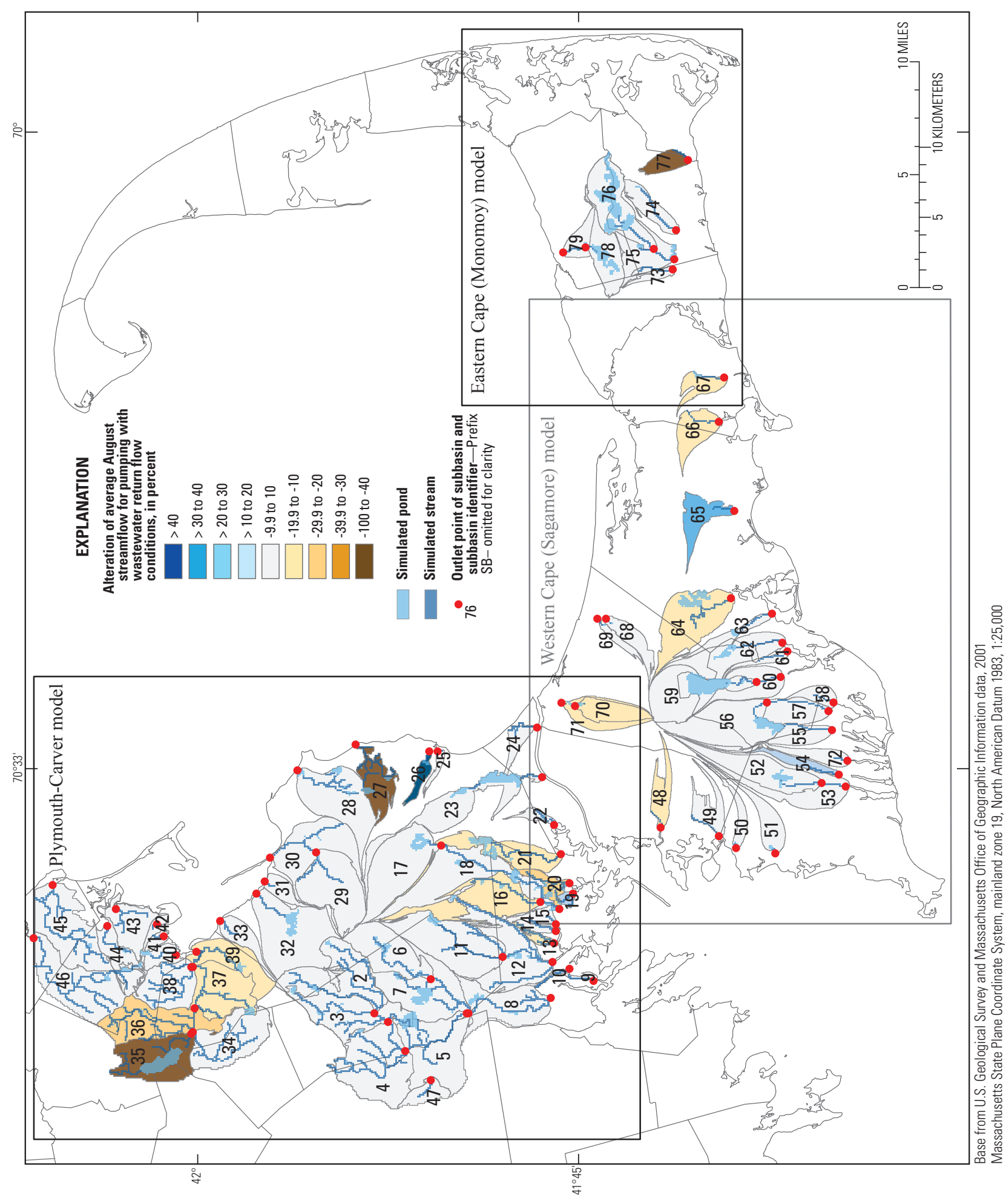

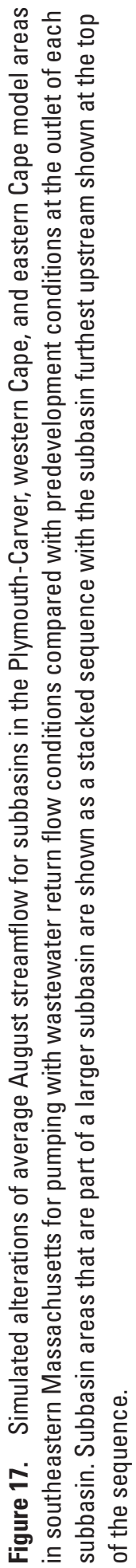


streamflows in map view. The gray-shaded areas show that simulated alterations of average August streamflow under pumping with wastewater return flow conditions were between -10 percent (depleted) and +10 percent (surcharged) for most of the subbasins in the study area.

\section{Alteration of Streamflows at Stream Model Cells}

The groundwater flow models provide streamflow and changes in streamflow for each 400-by 400 -ft stream cell in the study area. Consequently, groundwater flow models simulate streamflow alteration within subbasins as well as at subbasin outlets, in contrast to the topographically derived subbasins in the rest of the Commonwealth where alteration results are available only at subbasin outlets. Simulated streamflow alteration for pumping with wastewater return flow conditions by stream cell for August for the PlymouthCarver, western Cape, and eastern Cape model areas is shown in figures 18, 19, and 20, respectively. Changes in streamflow are shown as absolute differences and as percentages from predevelopment streamflows. An example of differences between results at stream cells and outlet points is provided by a comparison of streamflows at the outlet point of subbasin SB-2 with streamflows just downstream of Kings Pond in the unnamed tributary to South Meadow Brook (fig. 18). The simulated decrease in streamflow under pumping with wastewater return flow conditions at the outlet point of subbasin SB-2 was about $0.6 \mathrm{ft}^{3} / \mathrm{s}$ from a predevelopment streamflow of about $6.5 \mathrm{ft}^{3} / \mathrm{s}$ (about 9 percent). However, within this subbasin, there was a group of stream cells downstream of Kings Pond that showed a similar decrease in streamflow of about $0.7 \mathrm{ft}^{3} / \mathrm{s}$, but the predevelopment streamflow was lower, about $0.8 \mathrm{ft}^{3} / \mathrm{s}$, resulting in a larger percentage decrease of greater than 50 percent. Consequently, although the streamflow alteration at the subbasin scale was less than 10 percent, this particular subbasin contained a group of stream cells further upstream that showed alterations to streamflow greater than 50 percent. The benefit of using results from groundwater models for this analysis is that, although simulated streamflow alterations were summarized by subbasin to be consistent with previous studies, alterations at the scale of individual stream cells are also available so that spatial patterns of streamflow alteration within a particular subbasin can be evaluated (appendix 2).

\section{Alteration of Pond Levels}

Similar to streamflows, pond levels can either increase or decrease in response to pumping and wastewater return flows. The hydrologic position of wells and enhanced return flows in relation to ponds, the pumping and wastewater return flow rates, and the number of wells are factors that influence which ponds are affected by pumping and wastewater return flows. Increases or decreases in pond levels of less than $0.1 \mathrm{ft}$ were considered to be negligible. Consequently, the results described in this section reflect changes in pond levels of $0.1 \mathrm{ft}$ or greater. Simulated alterations are summarized in this section, but more detailed results for all simulated conditions are available in the pond water level shapefiles in the ArcMap project in appendix 2 .

\section{Long-Term Average Conditions}

The percentages of the total number of ponds where the difference in long-term average water levels was equal to or greater than $0.1 \mathrm{ft}$ (table 6) between predevelopment and pumping only conditions were 35 percent for the PlymouthCarver model, 85 percent for the western Cape model, and 85 percent for the eastern Cape model. For pumping with wastewater return flow conditions, the percentages were 28 percent for the Plymouth-Carver model, 67 percent for the western Cape model, and 75 percent for the eastern Cape model. Overall, a smaller percentage of ponds in the Plymouth-Carver region were influenced by pumping only or pumping with wastewater return flow conditions compared with ponds on Cape Cod. As expected, fewer ponds had a decrease in water levels when wastewater return flows were included in comparison with the pumping only conditions (table 6).

The largest decrease due to pumping was $4.8 \mathrm{ft}$ at Great South Pond in Plymouth (fig. 2; table 6). The largest decrease due to pumping with wastewater return flows was $4.6 \mathrm{ft}$, also at Great South Pond. The largest increase due to pumping with wastewater return flows was almost $0.5 \mathrm{ft}$ at an unnamed pond near Town Forest in Pembroke. Results for the western Cape model area show that the largest decrease due to pumping was $3.8 \mathrm{ft}$ at Mary Dunn Pond in Barnstable. The largest decrease due to pumping with wastewater return flows was $3.2 \mathrm{ft}$ at Long Pond in Falmouth. The largest increase due to pumping with wastewater return flows was $0.9 \mathrm{ft}$ at Wequaquet Lake in Barnstable (fig. 3). Results for the eastern Cape model area show that the largest decrease due to pumping was $4.7 \mathrm{ft}$ at Grassy Pond in Dennis. The largest decrease due to pumping with wastewater return flows was $3.4 \mathrm{ft}$, also at Grassy Pond. The largest increase due to pumping with wastewater return flows was $0.3 \mathrm{ft}$ at School House Pond.

\section{Average Monthly Conditions}

A greater percentage of ponds were affected by pumping only and pumping with wastewater return flow conditions on Cape Cod than in the Plymouth Carver region. An average of 37 and 28 percent of simulated ponds were influenced by pumping only and pumping with wastewater return flow conditions, respectively, in the Plymouth Carver region, compared with about 83 and 69 percent in the western Cape, and 86 and 76 percent in the eastern Cape model areas (table 6). The group of ponds that had the greatest changes in monthly water levels was fairly consistent throughout 

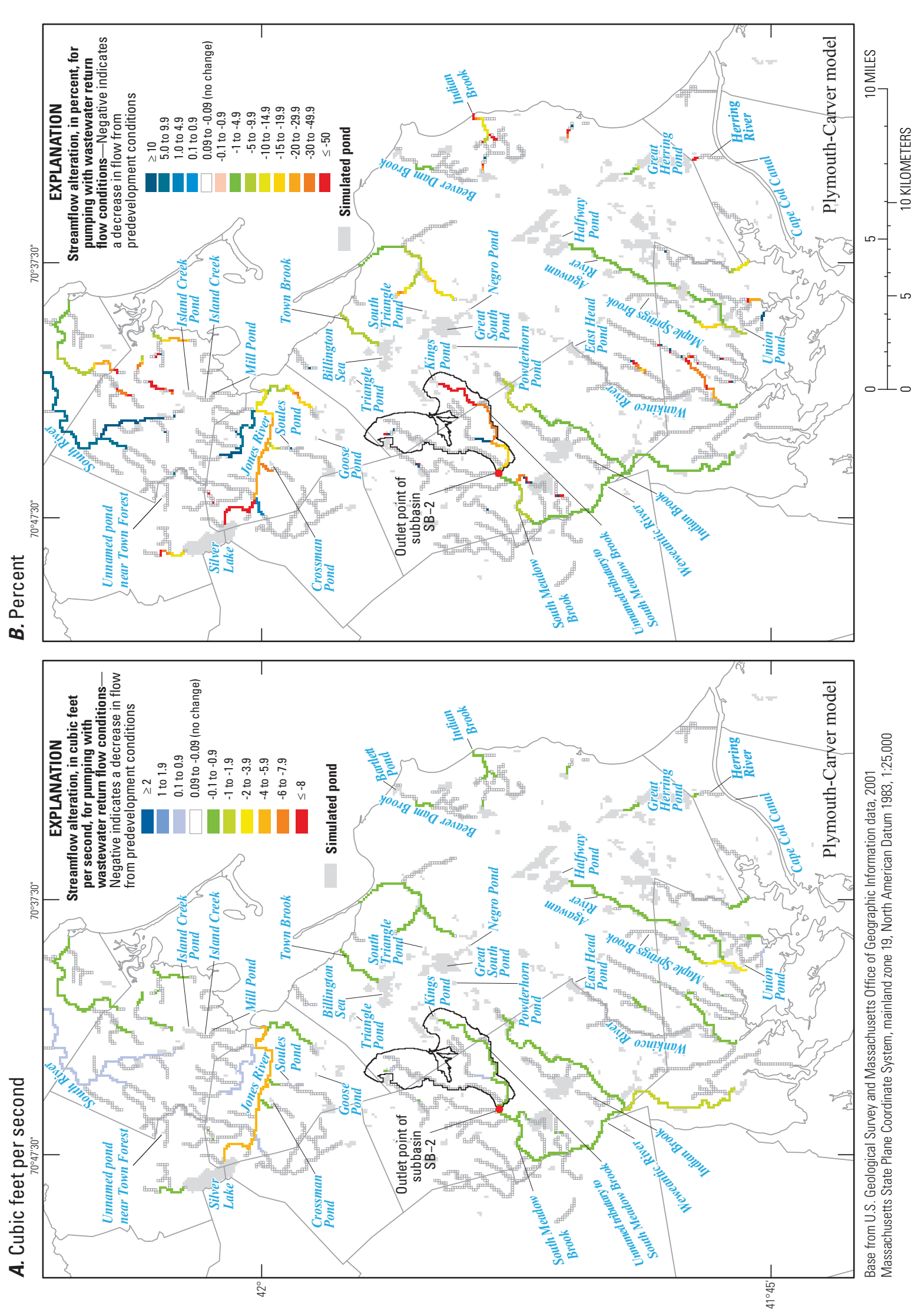

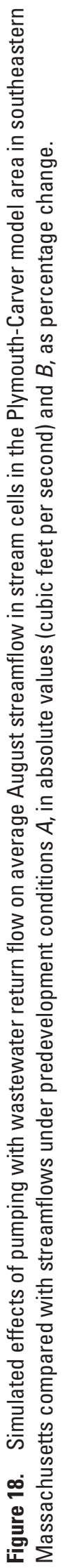



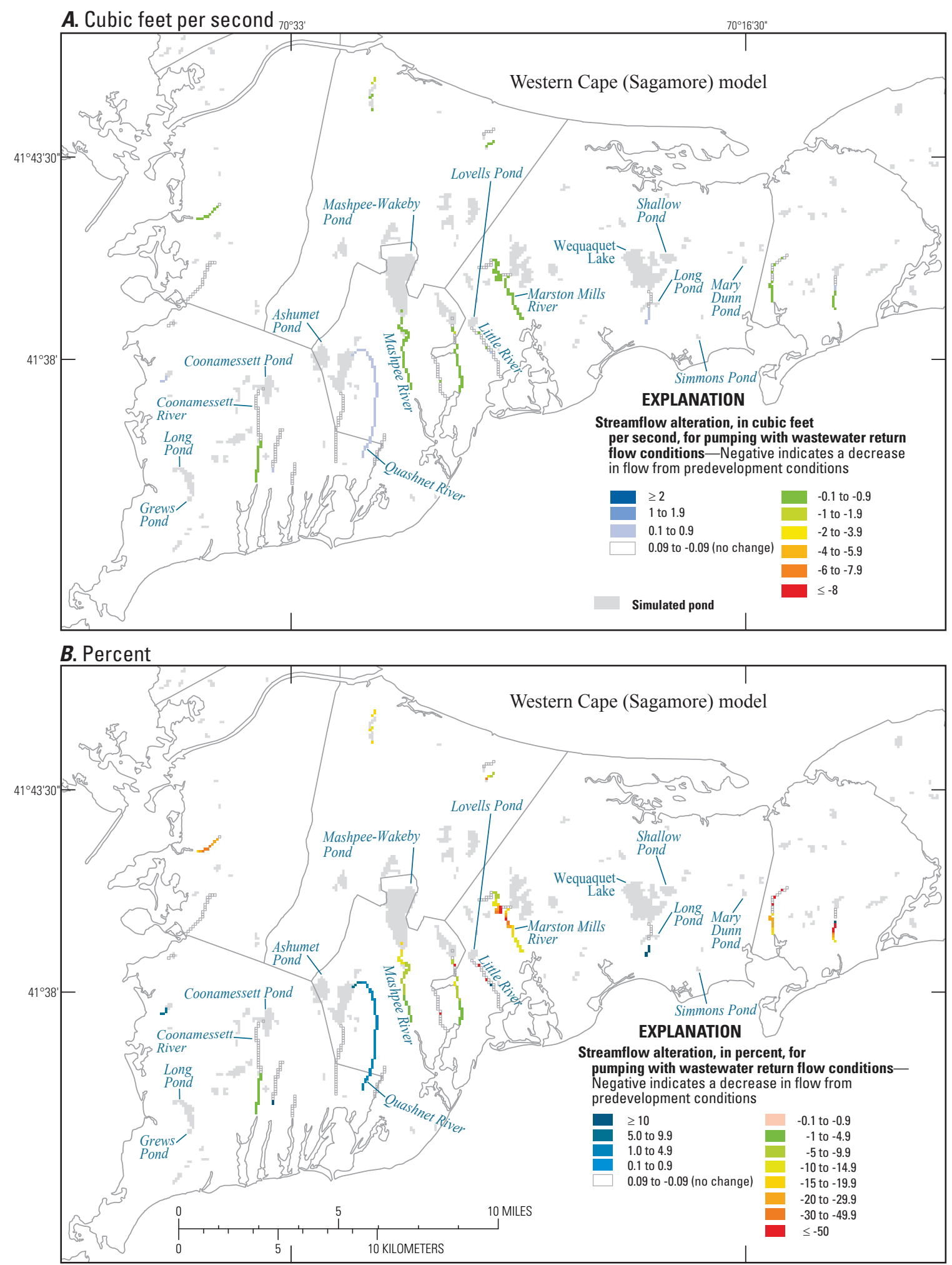

Base from U.S. Geological Survey and Massachusetts Office of Geographic Information data, 2001

Massachusetts State Plane Coordinate System, mainland zone 19, North American Datum 1983, 1:25,000

Figure 19. Simulated effects of pumping with wastewater return flow on average August streamflow in stream cells in the western Cape model area in southeastern Massachusetts compared with streamflows under predevelopment conditions $A$, in absolute values (cubic feet per second) and $B$, as percentage change. 
A. Cubic feet per second

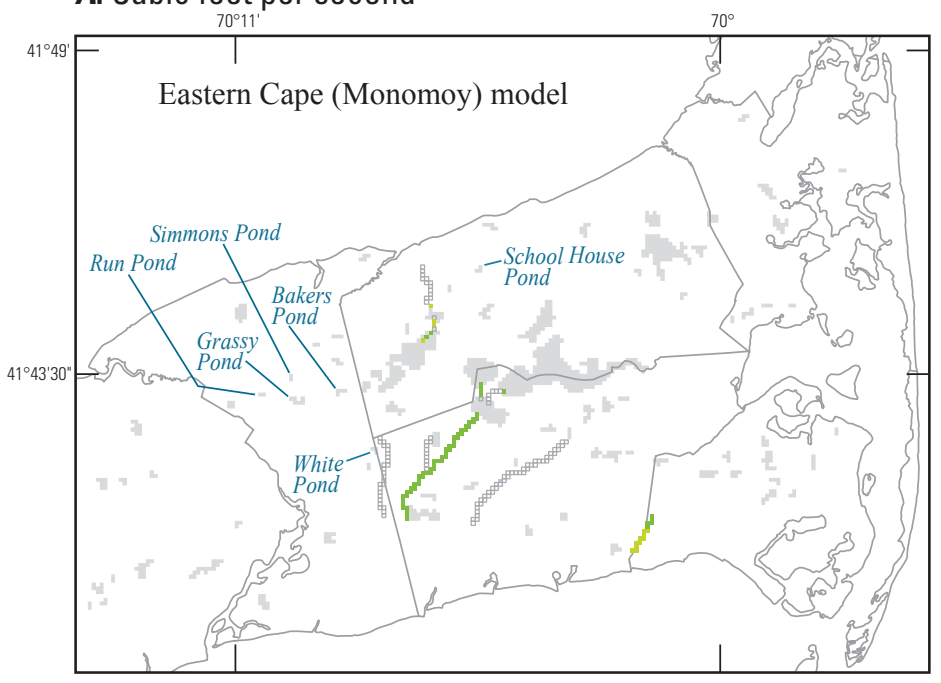

EXPLANATION

Streamflow alteration, in cubic

feet per second, for pumping with

wastewater return flow conditions-

Negative indicates a decrease in flow

from predevelopment conditions

$\geq 2$

1 to 1.9

0.1 to 0.9

0.09 to -0.09 (no change)

-0.1 to -0.9

-1 to -1.9

-2 to -3.9

-4 to -5.9

-6 to -7.9

$\leq-8$

Simulated pond

B. Percent

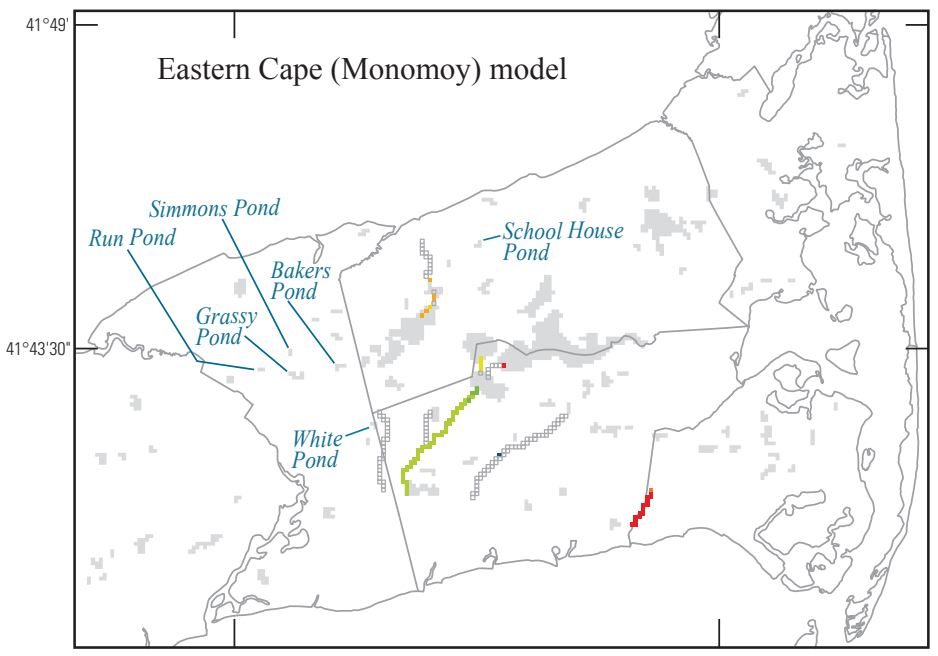

EXPLANATION

Streamflow alteration, in percent,

for pumping with wastewater

return flow conditions-Negative

indicates a decrease in flow

from predevelopment conditions

from predeve

$\geq 10$
5.0 to 9.9

5.0 to 9.9
1.0 to 4.9

0.1 to 0.9

0.09 to -0.09 (no change)

-0.1 to -0.9

-1 to -4.9

-10 to -14.9

-10 to -14.9

-15 to -19.9

-20 to -29.9
-30 to -49.9

$\leq-50$

Simulated pond

Base from U.S. Geological Survey and Massachusetts Office of Geographic Information

data, 2001, Massachusetts State Plane Coordinate System, mainland zone 19

North American Datum 1983, 1:25,000

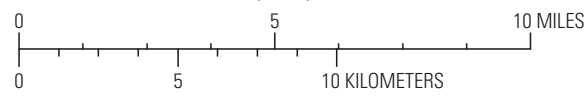

Figure 20. Simulated effects of pumping with wastewater return flow on average August streamflows in stream cells in the eastern Cape model area in southeastern Massachusetts compared with streamflows under predevelopment conditions $A$, in absolute values (cubic feet per second) and $B$, as percentage change. 
the year. These included Great South Pond, Negro Pond, Powderhorn Pond, South Triangle Pond, and Triangle Pond in the Plymouth-Carver model area (fig. 21); Long Pond in Falmouth, Grews Pond, Simmons Pond, Mary Dunn Pond, and Little Pond in the western Cape model area (fig. 22); and Grassy Pond, Bakers Pond, Simmons Pond, Run Pond, and White Pond in the eastern Cape model area (fig. 23). Changes in average August pond water levels for pumping only and for pumping with wastewater return flow conditions compared to predevelopment conditions are shown in figures 21 through 23.

Hydrographs of simulated average monthly pond levels for all ponds are included in appendix 2. The hydrographs shown in figure 24 are two examples of the effects of simulated average monthly pond-level changes from the Plymouth-Carver model area, showing differing effects of pumping and wastewater return flows. The hydrograph of Goose Pond (figs. 21 and 24) shows that pond level increased under pumping with wastewater return flow conditions in comparison with predevelopment conditions and decreased under pumping only conditions in comparison with predevelopment conditions, whereas the hydrograph of Triangle Pond (figs. 21 and 24) shows that pond levels decreased in comparison with predevelopment conditions for both pumping only and pumping with wastewater return flow conditions.

In general, monthly pond water level alterations were fairly consistent throughout the year. However, a few ponds in the Plymouth-Carver model area showed slightly more variability by month; these included Mill Pond, Soules Pond, Crossman Pond, and Silver Lake. Mill Pond and Soules Pond are small ponds that were simulated in the same model cells as streams and, therefore, changes in streamflow may have influenced the pond levels in these areas. Crossman Pond is an isolated pond located between a stream and a production well, and the pond level could be influenced by the combined effect of those nearby features. Silver Lake is a large reservoir, and resulting water levels are related to the simulated monthly rates of withdrawal from the lake (Silver Lake is discussed in greater detail in the "Limitations" section of this report).

As with long-term average results, Great South Pond (fig. 21) had the largest monthly change among ponds in the Plymouth-Carver model, with consistent decreases in each month of about 4.8 and $4.6 \mathrm{ft}$ for pumping only conditions and for pumping with wastewater return flow conditions, respectively. However, Great South Pond is a special case due to the relatively consistent withdrawal directly from the pond. Ponds in the Plymouth-Carver model with the next greatest change are shown in table 6 . These include Triangle Pond, with a consistent monthly decrease of about $4 \mathrm{ft}$ under pumping only conditions, and Negro Pond, with a consistent monthly decrease of about $3.5 \mathrm{ft}$ under pumping with wastewater return flow conditions. In general, the largest increase in pond level $(0.4 \mathrm{ft})$ in response to pumping with wastewater return flows was at Goose Pond (fig. 21). In the western Cape model, Mary Dunn Pond and Long Pond in
Falmouth (fig. 22) had the largest simulated decreases in monthly water levels due to pumping, and Long Pond had the largest decrease due to pumping with wastewater return flows. The largest increases due to pumping with wastewater return flows were at Shallow Pond ( $0.9 \mathrm{ft})$ and Wequaquet Lake $(0.8 \mathrm{ft})$. In the eastern Cape model area, Grassy Pond (fig. 23) had the largest simulated decrease in monthly water level due to both pumping only and pumping with wastewater return flows (5.0 and $3.7 \mathrm{ft}$, respectively). The largest increase due to pumping with wastewater return flow was at School House Pond $(0.4 \mathrm{ft})$.

\section{Landscape Characteristics in Contributing Areas}

Once contributing areas (subbasins and hydrologic units) were delineated, the following landscape characteristics described in Weiskel and others (2010) and Armstrong and others (2011) for the rest of Massachusetts were determined for contributing areas in southeastern Massachusetts:

- channel slope;

- total undammed stream length;

- percent wetland in a 787.4-ft (240-meter [m]) buffer $393.7 \mathrm{ft}(120 \mathrm{~m})$ from the stream centerline;

- percent agriculture in a 787.4-ft $(240 \mathrm{~m})$ buffer $393.7 \mathrm{ft}$ $(120 \mathrm{~m})$ from the stream centerline;

- percent forest;

- percent open water;

- percent impervious cover;

- percent sand and gravel; and

- the average August withdrawal ratio (ratio of withdrawals to unaltered streamflows).

These landscape characteristics were determined for all 78 subbasins (table 3). Percent impervious cover was also determined at the hydrologic-unit (or local) scale (table 4; fig. 5). The characteristics were determined under predevelopment conditions for all 78 subbasins (table 3), including the 61 headwater subbasins (figs. 4 and 6) and the 17 nested subbasins that contain one or more overlapping upstream subbasins (figs. 4 and 7). Landscape characteristics were determined for each of the 17 nested subbasins in the total drainage area to the respective stream outlet point. The percent impervious cover was the only landscape characteristic that also was calculated by hydrologic unit (table 4). This was done for consistency with the study for the rest of Massachusetts in Weiskel and others (2010).

In each groundwater model, the physical properties of streams were simplified and mapped to the regional model grids, as represented in the STR package input file of 

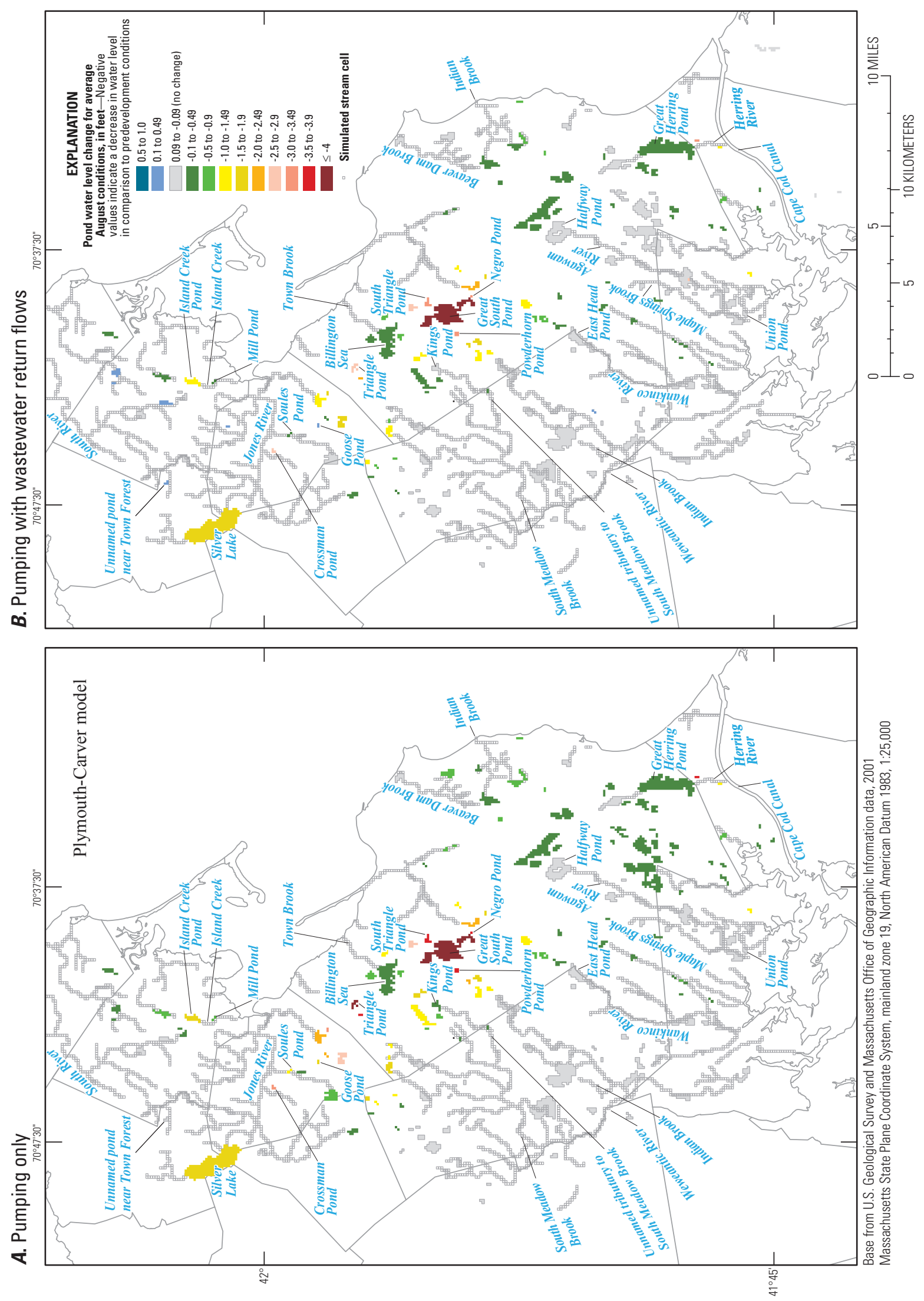

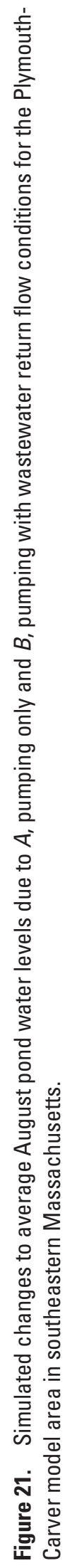



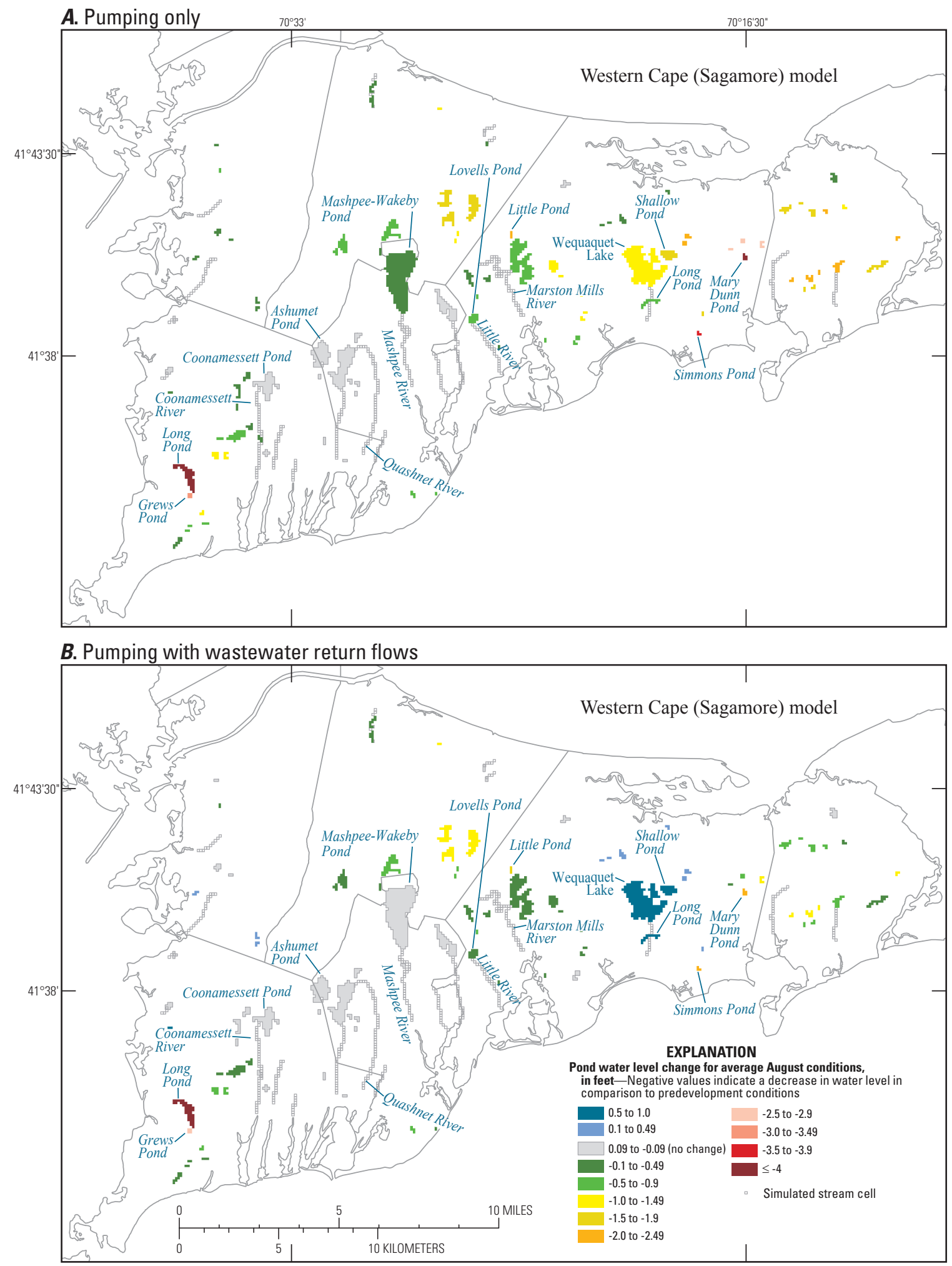

Base from U.S. Geological Survey and Massachusetts Office of Geographic Information data, 2001

Massachusetts State Plane Coordinate System, mainland zone 19, North American Datum 1983, 1:25,000

Figure 22. Simulated changes to average August pond water levels due to $A$, pumping only and $B$, pumping with wastewater return flow conditions for the western Cape model area in southeastern Massachusetts. 


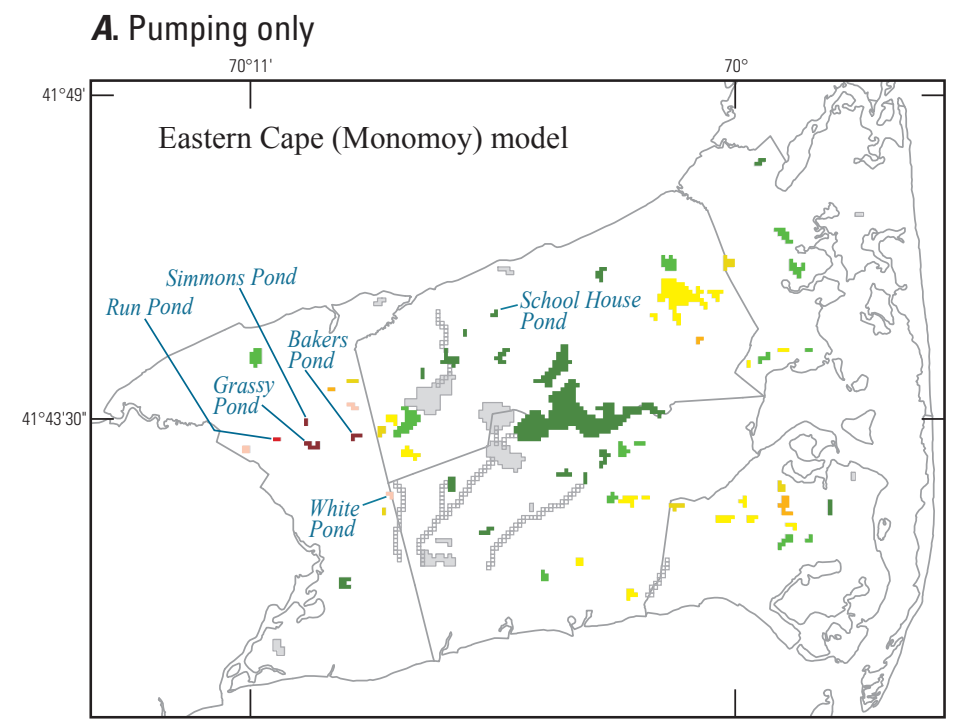

\section{EXPLANATION}

Pond water level change for average August conditions, in feet-Negativ values indicate a decre predevelopment conditions

0.5 to 1.0 0.1 to 0.49 0.09 to -0.09 (no change)

B. Pumping with wastewater return flows

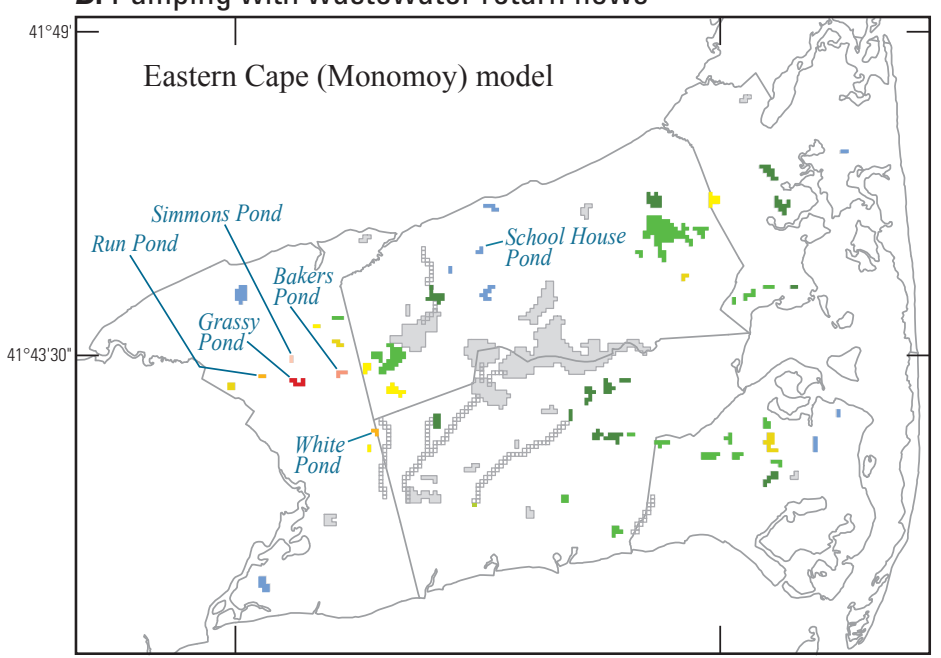

-0.1 to -0.49

-0.5 to -0.9

-1.0 to -1.49

-1.5 to -1.9

-2.0 to -2.49

-2.5 to -2.9

-3.0 to -3.49

-3.5 to -3.9

$\leq-4$

Simulated stream cell

Base from U.S. Geological Survey and Massachusetts Office of Geographic Information

data, 2001, Massachusetts State Plane Coordinate System, mainland zone 19

North American Datum 1983, 1:25,000

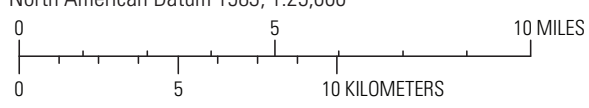

Figure 23. Simulated changes to average August pond water levels due to $A$, pumping only and $B$, pumping with wastewater return flow conditions for the eastern Cape model area in southeastern Massachusetts. 


\section{A. Goose Pond}

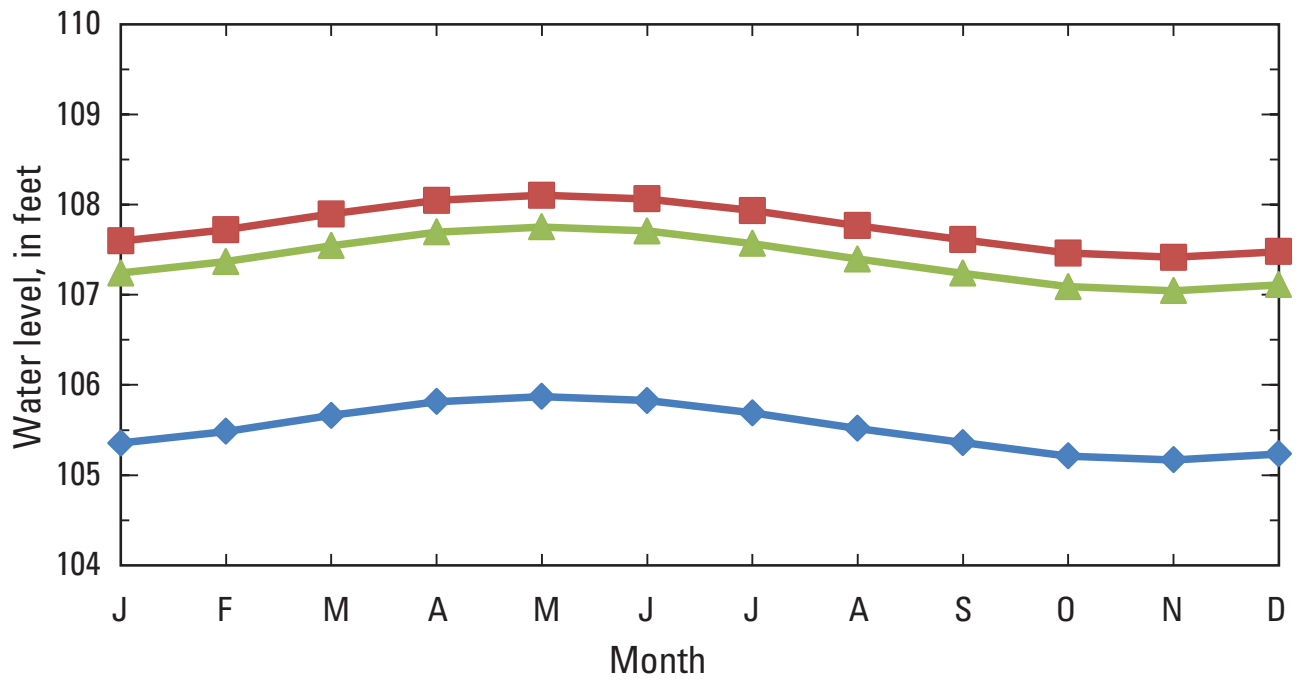

B. Triangle Pond

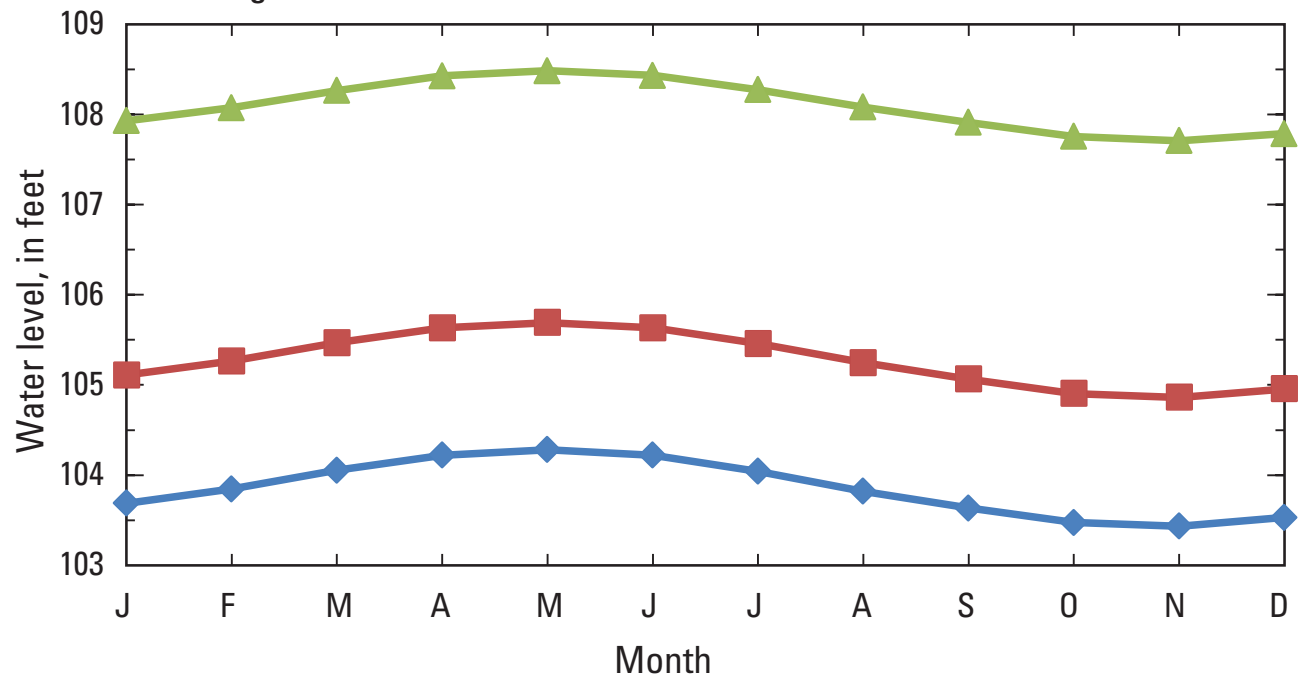

\section{EXPLANATION}

Water level

$\rightarrow$ Predevelopment

$\sim$ Pumping only

Pumping with wastewater

return flow

Figure 24. Hydrographs from the Plymouth-Carver model area of simulated average monthly pond levels for predevelopment, pumping only, and pumping with wastewater return flow conditions for $A$, Goose Pond and $B$, Triangle Pond in southeastern Massachusetts. 
Simulated Responses of Streams and Ponds to Groundwater Withdrawals and Wastewater Return Flows in Mass.

MODFLOW (Prudic, 1989). Consequently, the calculated results for the two landscape characteristics that involved length (channel slope and total undammed stream length) were based on a value of $400 \mathrm{ft}$, the length of simulated stream in each model cell. Because of the gridded nature of the groundwater models, slope could not be calculated in the same manner as in Armstrong and others (2011). Elevations used to calculate channel slope were based on those specified in the STR package input file. This characteristic in Armstrong and others (2011) was known as local channel slope and was based on a 984.3-ft (300-m)-diameter circle about a sampling point. In this study, channel slope was calculated by determining the difference in elevation of the streambed between the upstream and downstream ends of each hydrologic unit, then dividing by the length between these points (length was determined as the number of stream cells between each point, multiplied by $400 \mathrm{ft}$ ). This result then was multiplied by 100 to yield slope in percent. Even though slope (fig. 25A) was calculated over a greater distance compared with that in Armstrong and others (2011), the resulting slope values overall were not as steep as most of those of the Massachusetts water indicator subbasins of Weiskel and others (2010) and the local channel slope at 669 fish sampling sites of Armstrong and others (2011). This reflects the low topographic relief in southeastern Massachusetts relative to the rest of the Commonwealth.

The total length of undammed main stem and tributary streams was calculated between dams in both the upstream and downstream directions from the outlet point of each hydrologic unit. Some undammed lengths include streams located in more than one hydrologic unit for hydrologic units located between other hydrologic units (for example hydrologic unit HU-36, which has the same undammed reach length as hydrologic units HU-34 and HU-35). The straightline distance through simulated ponds was also included in the total length if no simulated stream cells were located in the pond because it was assumed that aquatic organisms could move into and through a pond (for example, Bartlett Pond in Beaver Dam Brook in subbasin SB-28 in the Plymouth-Carver model area; figs. 2, 5, and 6). This characteristic did not rely on hydrologic unit or subbasin boundaries.

Geographic information system (GIS) processing was used to determine the area of impervious cover, forest, open water, and sand and gravel in each subbasin and was then divided by the total area of the subbasin to obtain the percent area of each landscape characteristic. The percent area of wetlands and agriculture in a 787.4-ft $(240-\mathrm{m})$ buffer around each stream (Armstrong and others, 2011) was determined by using the same method.

Unlike the other landscape characteristics, the percent impervious cover also was calculated for each hydrologic unit by using the same method used for the subbasins. The same GIS datasets of land cover in 1992, impervious cover, and sand and gravel used to determine the characteristics in Armstrong and others (2011) were used in this study for consistency between the studies. However, because more recent versions of land cover for 2006 (Fry, 2011) and locations of dams (Massachusetts Office of Geographic Information, 2012) were available, those characteristics were also determined by using these datasets for this analysis. The criteria for land cover determination used in the 2006 dataset differed from those of the 1992 dataset, which accounted for a portion of the difference in the results presented in table 3 between the respective years.

Simulated average August streamflows were used to calculate the average August withdrawal ratio for subbasins in the three model areas in southeastern Massachusetts. Armstrong and others (2011) determined that the withdrawal ratio (ratio of withdrawals to unaltered streamflows) of median August streamflow was an important characteristic in predicting fluvial fish abundance. However, in this analysis, the withdrawal ratio of average, not median, August streamflow was calculated because the groundwater models simulate only average monthly streamflows.

Boxplots were developed to illustrate the similarity of the landscape characteristics determined for the hydrologic units and subbasins for southeastern Massachusetts in this study to the 1,379 Massachusetts water indicator subbasins (Weiskel and others, 2010; Massachusetts Department of Environmental Protection, 2014a) and the subbasins for 669 fish sampling sites (Armstrong and others, 2011) for the rest of Massachusetts (fig. 25). Channel slope, percent wetland in a 787.4-ft (240-meter) buffer, withdrawal ratio for median August streamflow, and percent impervious cover were used to predict fluvial fish abundance in Armstrong and others (2011) and for determining the WMA biological category of a subbasin (Massachusetts Department of Environmental Protection, 2014b). Boxplots were developed to compare landscape characteristics of subbasins used in the three studies (fig. 25). Additional boxplots compare the remaining five landscape characteristics that were computed for the 669 fish sampling sites and those delineated in this analysis (fig. 26).

Although most landscape characteristics were similar, channel slope, percent sand and gravel, undammed stream length, and percent open water showed somewhat larger differences among the studies than other characteristics (figs. 25 and 26). The boxplots of channel slope (fig. 25A) are separated into one graph for each report for comparison. Median channel slopes for the Massachusetts water indicator and fish sampling site subbasins were similar at 0.4 and 0.5 percent, respectively, and median slope was 0.2 percent for the southeastern Massachusetts hydrologic units. The August withdrawal ratios (fig. $25 \mathrm{C}$ ) are separated into two graphs to indicate that a difference exists in how the respective values were calculated, but the graphs are juxtaposed so that the resulting values from each report can be compared (median values were 6.9, 4.3, and 8.3 percent for Massachusetts water indicator, fish sampling site, and southeastern Massachusetts subbasins, respectively). Percent wetland (fig. 25B) and percent impervious cover (fig. $25 \mathrm{D}$ ) were calculated similarly for each report and are shown on the same graph for comparison. Median values for percent wetland were 24.4, 14.3, and 12.2 for Massachusetts water indicator, fish sampling 
A. Channel slope

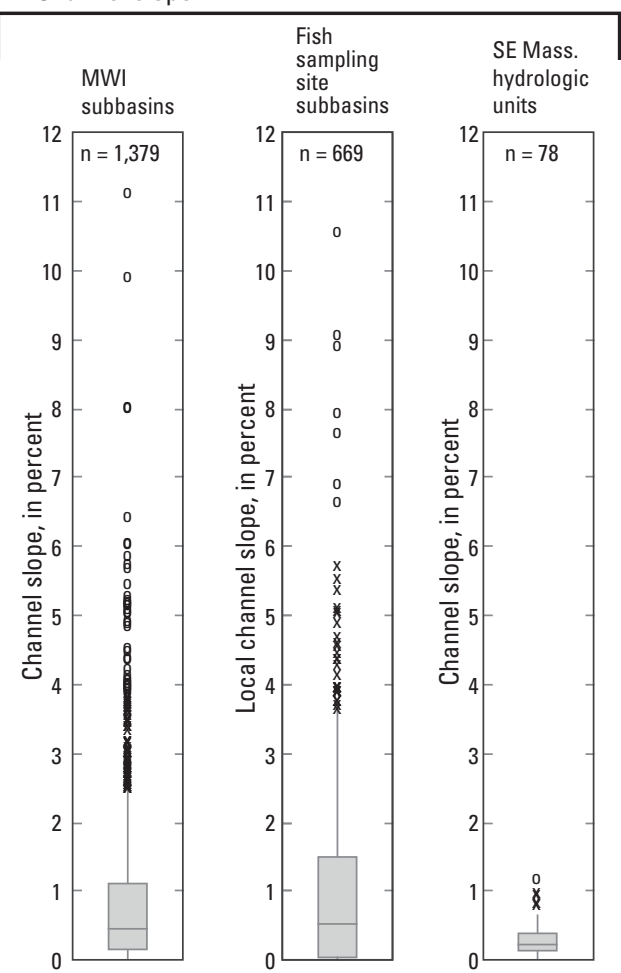

C. August withdrawal ratio

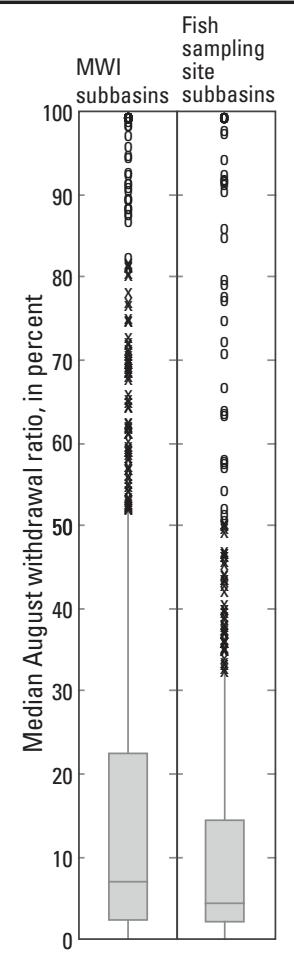

B. Percent wetland in a $787.4 \mathrm{ft}(240 \mathrm{~m})$ buffer

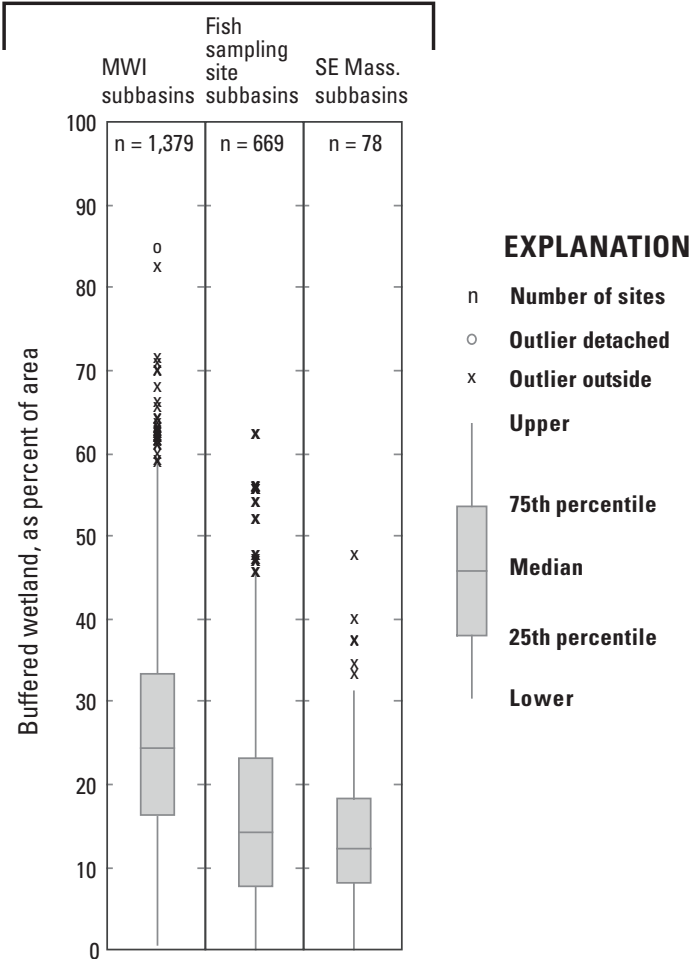

D. Percent impervious cover

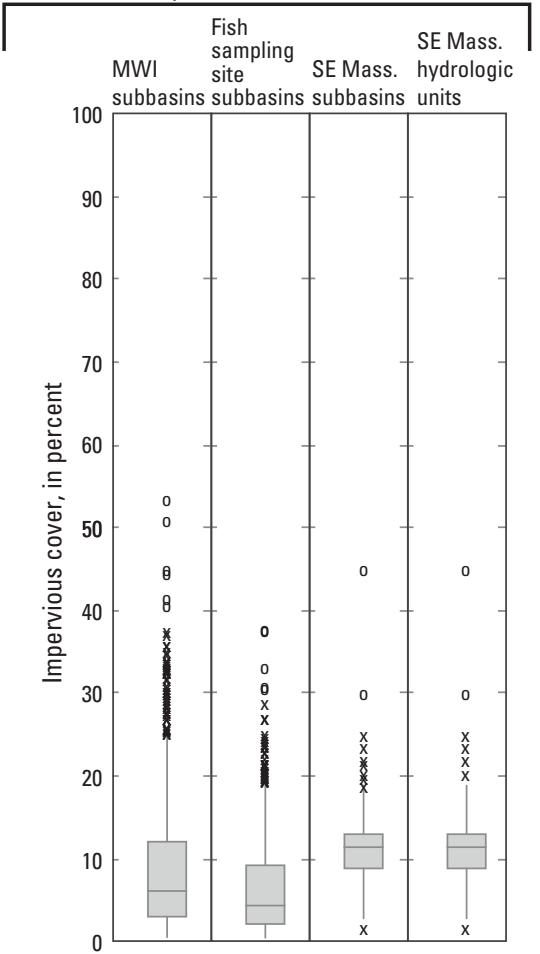

Figure 25. Comparison of $A$, channel slope, $B$, percent wetland in a 787.4-foot (ft; 240-meter [m]) buffer, $C$, August withdrawal ratio, and $D$, percent impervious cover for Massachusetts water indicator (MWI) subbasins, fish sampling site subbasins, and southeastern Massachusetts (SE Mass.) hydrologic units and subbasins. 


\section{A. Percent forest}

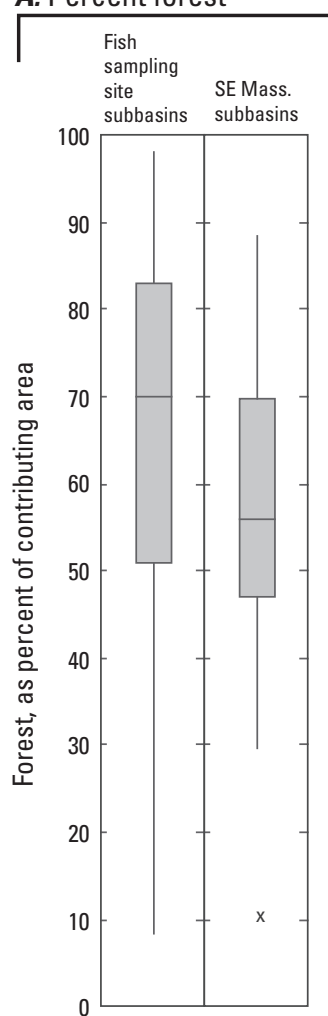

C. Percent sand and gravel

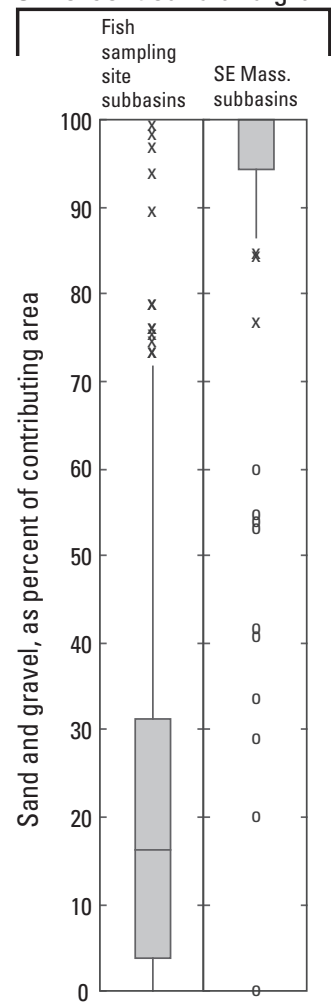

B. Drainage area

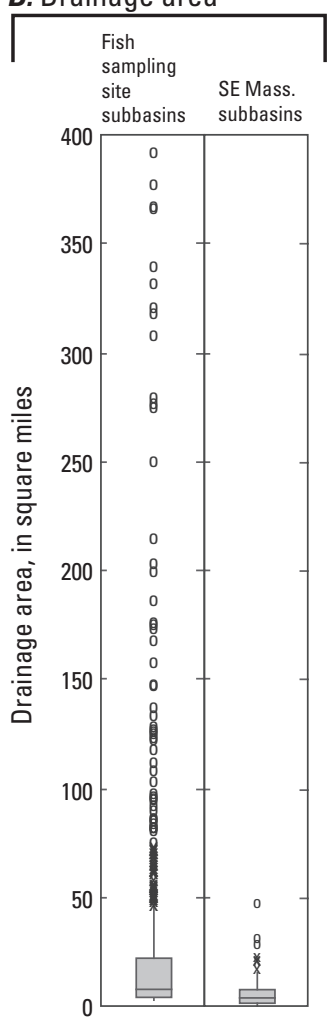

D. Undammed stream length

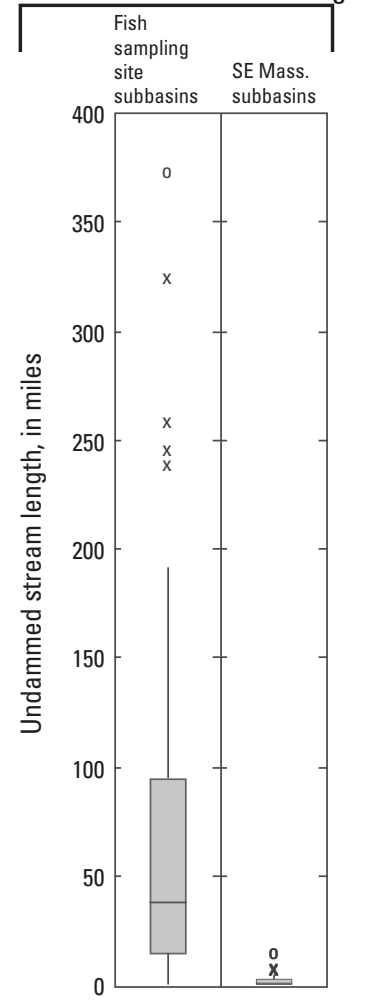

E. Percent open water

EXPLANATION

- Outlier detached

$x$ Outlier outside

Upper

75th percentile

Median

25th percentile

Lower

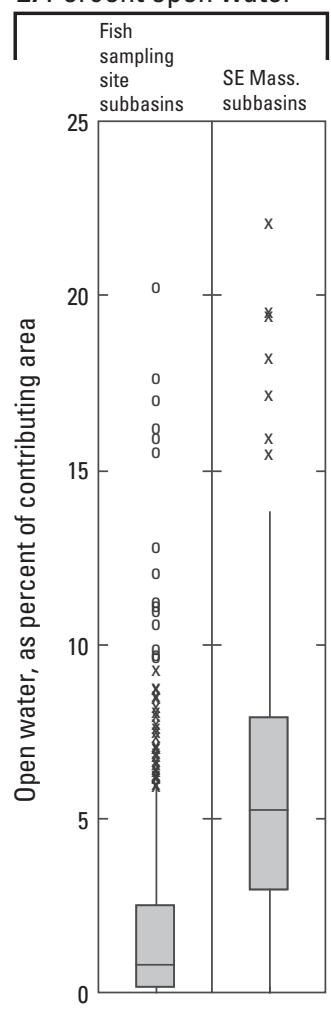

Figure 26. Comparison of $A$, percent forest, $B$, drainage area, $C$, percent sand and gravel, $D$, undammed stream length, and $E$, percent open water for fish sampling site subbasins and southeastern Massachusetts (SE Mass.) subbasins. 
site, and southeastern Massachusetts subbasins, respectively. Median values for impervious cover were 6.0 percent for Massachusetts water indicator subbasins, 4.2 percent for fish sampling site subbasins, and about 11 percent for southeastern Massachusetts subbasins and hydrologic units.

The remaining five landscape characteristics for the subbasins for the 669 fish sampling sites (Armstrong and others, 2011) and the subbasins delineated for this study are shown on the same graph (fig. 26). Percent forest (fig. 26A) and drainage area (fig. 26B) are similar, but percent sand and gravel (fig. 26C), undammed stream length (fig. 26D), and percent open water (fig. 26E) differ substantially between the areas. Medians for percent forest were 70.1 and 55.8 for fish sampling site and southeastern Massachusetts subbasins, respectively, whereas medians for drainage area were 7.4 and $3.5 \mathrm{mi}^{2}$ for fish sampling site and southeastern Massachusetts subbasins, respectively. In contrast, medians for percent sand and gravel values were 16 and 100 for fish sampling site and southeastern Massachusetts subbasins, respectively. The large sand and gravel aquifers found in southeastern Massachusetts compared with the rest of the Commonwealth account for this difference. Undammed reach lengths also differed substantially, with medians of 38.7 and 1.7 miles for fish sampling site and southeastern Massachusetts subbasins, respectively. Medians for open water as a percentage of contributing area were 0.8 and 5.2 for fish sampling site and southeastern Massachusetts subbasins, respectively.

Compared with the rest of Massachusetts, there are large areas of southeastern Massachusetts where precipitation that falls on the land surface will recharge groundwater and then ultimately discharge directly to the coast without flowing into a stream. These are the land areas not covered by the hydrologic units shown in figure 5. Results of different analyses described in the reports of Walter and others (2004), Walter and Whealan (2005), Masterson and others (2009), and Masterson and Walter (2009) show similar areas of land that discharge directly to the coast in southeastern Massachusetts. The area of the Plymouth-Carver model represents a transition zone between the high topographic relief found to the north and west for the rest of Massachusetts and the low topographic relief of Cape Cod. Southeastern Massachusetts also contains many groundwater subbasins that are isolated and do not directly touch another subbasin. A few of these areas exist in the Plymouth-Carver region (for example, headwater subbasins SB-22, SB-24, SB-25, and SB-26), but many more exist on Cape Cod (for example, headwater subbasins SB-48, SB-51, SB-67, and SB-77; figs. 5 and 6). These isolated subbasins are separated by land areas that discharge directly to the coast.

\section{Limitations}

Limitations arise in the use of a numerical model in which both time and space are discretized to simulate realworld hydrologic processes. The size of the grid cells of the models used in this analysis is at a resolution suitable for regional studies ( $400 \mathrm{ft}$ by $400 \mathrm{ft}$ ). The regional nature of these models is useful in identifying local areas that may be of concern to resource managers by incorporating production wells and other water-use data, aquifer geometry and watertransmitting properties, locations of surface water features such as ponds and streams, and rates of recharge to the aquifer. However, once an area of interest is identified from regional model results, this regional resolution may not be suitable to answer questions in areas of localized interest. To address more local issues, a subregional model that is hydraulically connected to the regional model but with a smaller, more suitable spatial extent and discretization could be used.

In this study, existing regional groundwater models were used to investigate changes in surface-water features (streamflows and pond levels) between predevelopment conditions and pumping only and pumping with wastewater return flow conditions. Although groundwater models provide results for pond levels and streamflows, surface-water features generally are represented implicitly as hydraulic boundaries, and as such, these results are subject to limitations.

Groundwater models are calibrated to both water levels and streamflows; the greater the number of calibration points with reliable data, the greater the confidence in the model results. Consequently, more uncertainty in simulated results exists in areas that lack, or have fewer, calibration points compared with areas where more data are available; regional models may contain areas with relatively sparse calibration data.

Another potential limitation of using the existing models to determine changes in streamflows and pond levels is the representation of the artificial means that have been used to control pond levels (addition or removal of boards and other water level control structures), subsequent outflows to streams, and the length of time that a certain pond elevation was maintained. Subsequent analysis of the model results shows that these outflow elevations are important to downstream flows and to changes in those streamflows in response to changing pumping and wastewater return flows. Pond levels and their outlet elevations were obtained from topographic maps for each of the three modeled areas. At the regional scale, this resolution was considered acceptable, but when comparing local streamflows that also may include outflows from ponds, this resolution may not be adequate. Consequently, more uncertainty could be associated with streamflows derived as outflows from ponds with estimated outlet elevations.

The Silver Lake/Jones River outlet in Kingston (figs. 27 and 28) provides an example of where understanding the pond outlet flows to the head of the Jones River is critical to properly assess the potential effects of pumping on streamflow at the downstream gage. In this case, the Silver Lake pond elevation was estimated from a topographic map and used as the pond outlet stream elevation. Based on this elevation, the simulated pond contribution to long-term average surface streamflow to the Jones River was about $8.4 \mathrm{ft}^{3} / \mathrm{s}$ for predevelopment conditions (fig. 29), which contributed to the 


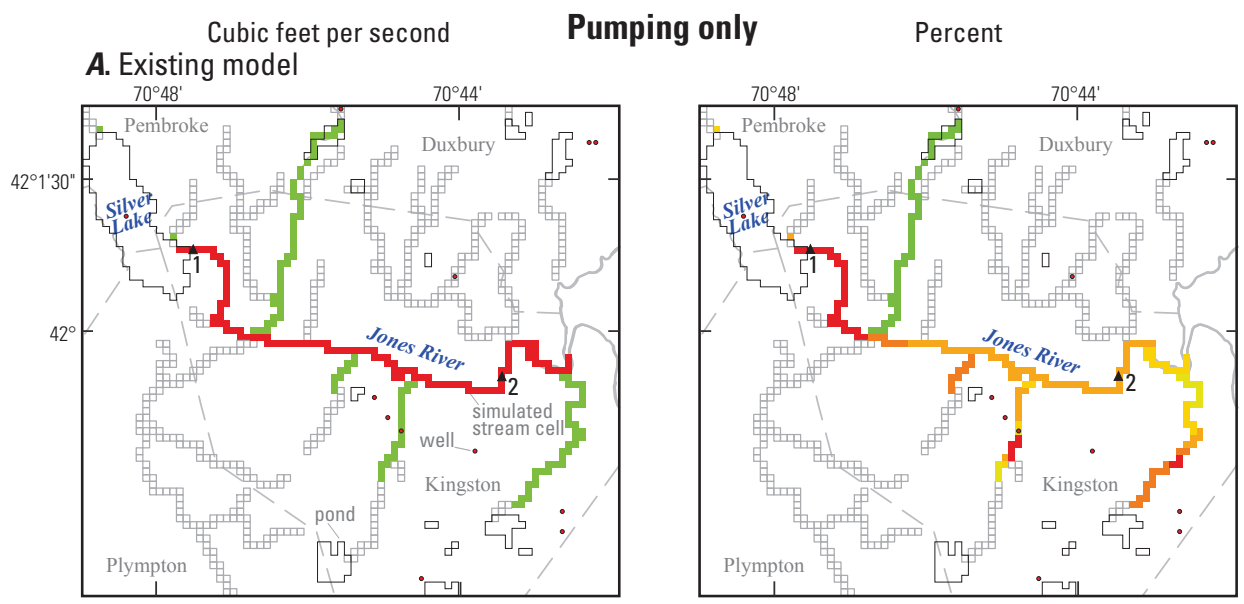

B. Alternative analysis with no pond outlet flow from Silver Lake to the Jones River

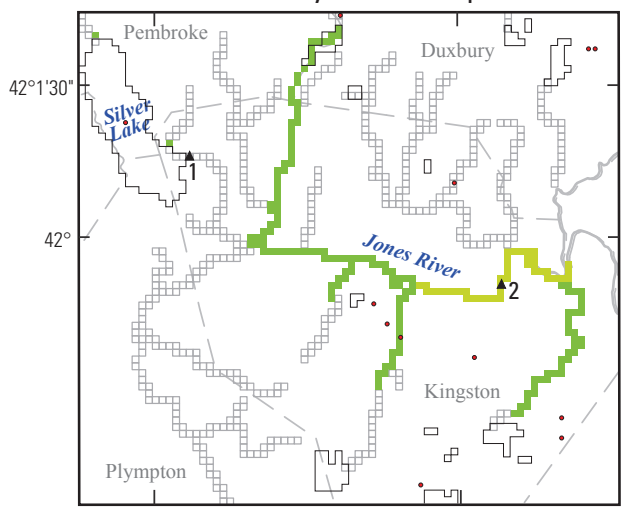

EXPLANATION

Streamflow change, in cubic feet

per second-Negative values indicate a decrease in November streamflow in comparison

to predevelopment conditions

$\square 0.09$ to -0.09 (no change)

-0.1 to -0.9

-1 to -1.9

-2 to -3.9

-4 to -5.9

-6 to -7.9

$\leq-8$

$\triangle_{2}$ Streamflow comparison site and identifier

$\ulcorner$ Pond outline

- Well

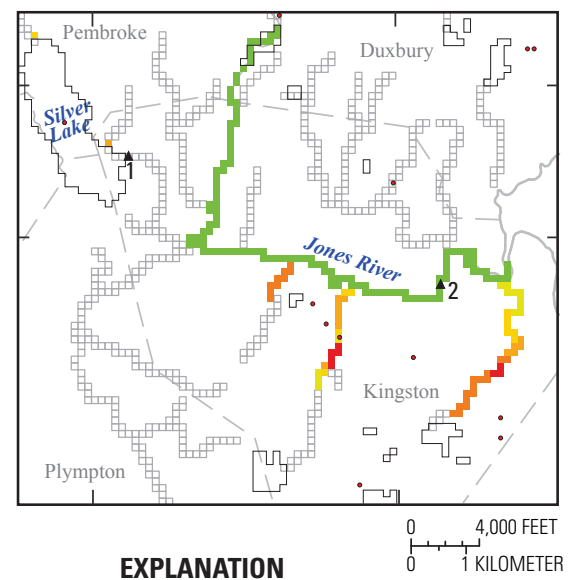

Streamflow change, in percent-Negative values indicate a decrease in November streamflow in comparison to predevelopment conditions

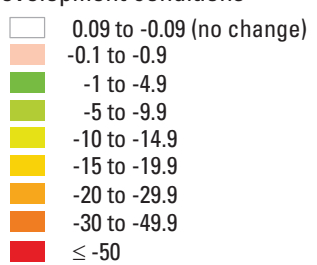

Figure 27. Simulated effect of pumping and percentage change on November streamflow compared with predevelopment conditions for $A$, the existing model and $B$, the alternative analysis with no pond outlet flow from Silver Lake to the Jones River area in southeastern Massachusetts. 


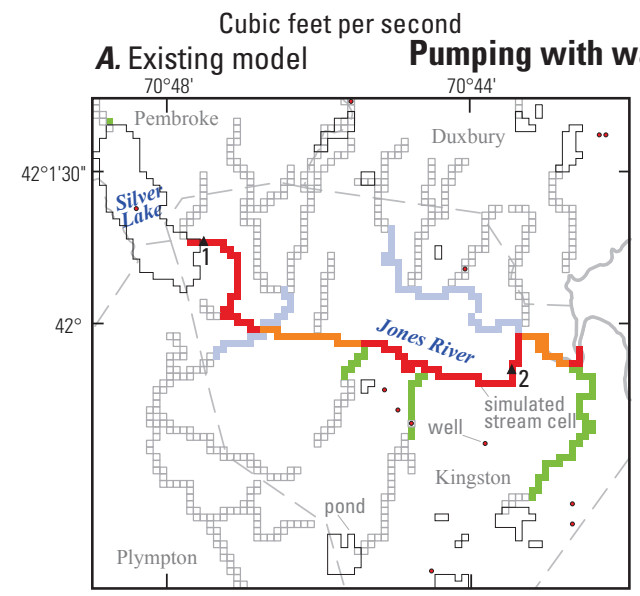

Percent

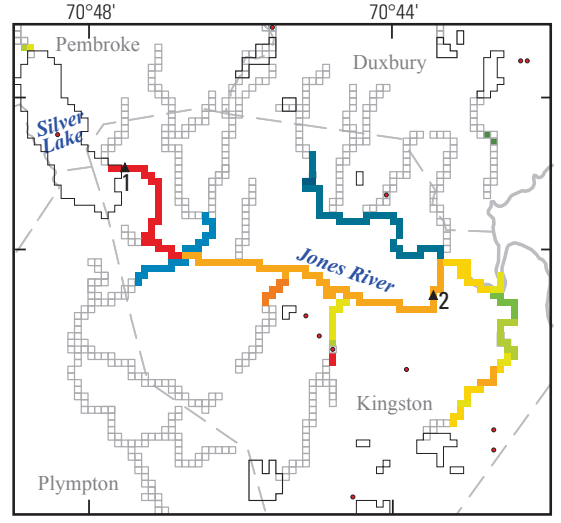

B. Alternative analysis with no pond outlet flow from Silver Lake to the Jones River

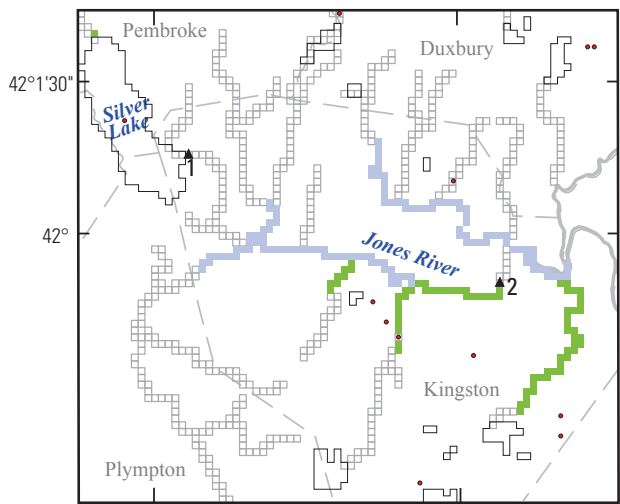

EXPLANATION

Streamflow change, in cubic feet per

second-Negative values indicate a decrease

in November streamflow in comparison

to predevelopment conditions

$\geq 2$

1 to 1.9

0.1 to 0.9

0.09 to -0.09 (no change)

-0.1 to -0.9

-1 to -1.9

-2 to -3.9

-4 to -5.9

-6 to -7.9

$\leq-8$

$\triangle 2$ Streamflow comparison site and identifier

$\neg$ Pond outline

- Well

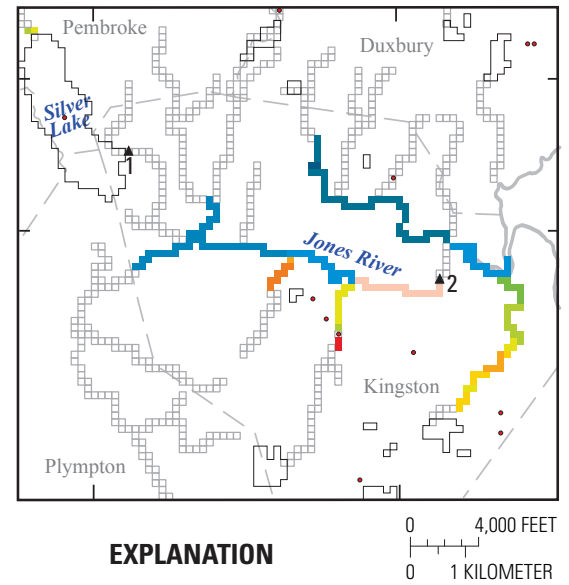

Streamflow change, in percent-Negative values indicate a decrease in November streamflow in comparison to predevelopment conditions

$$
\begin{array}{|l|}
\hline \geq 10 \\
5.0 \text { to } 9.9 \\
1.0 \text { to } 4.9 \\
0.1 \text { to } 0.9 \\
0.09 \text { to }-0.09 \\
-0.1 \text { to }-0.9 \\
-1 \text { to }-4.9 \\
-5 \text { to }-9.9 \\
-10 \text { to }-14.9 \\
-15 \text { to }-19.9 \\
-20 \text { to }-29.9 \\
-30 \text { to }-49.9 \\
\leq-50
\end{array}
$$$$
0.09 \text { to }-0.09 \text { (no change) }
$$

Figure 28. Simulated effect of pumping with wastewater return flows and percentage change on November streamflow compared with predevelopment conditions for $A$, the existing model and $B$, the alternative analysis with no pond outlet flow from Silver Lake to the Jones River area in southeastern Massachusetts. 

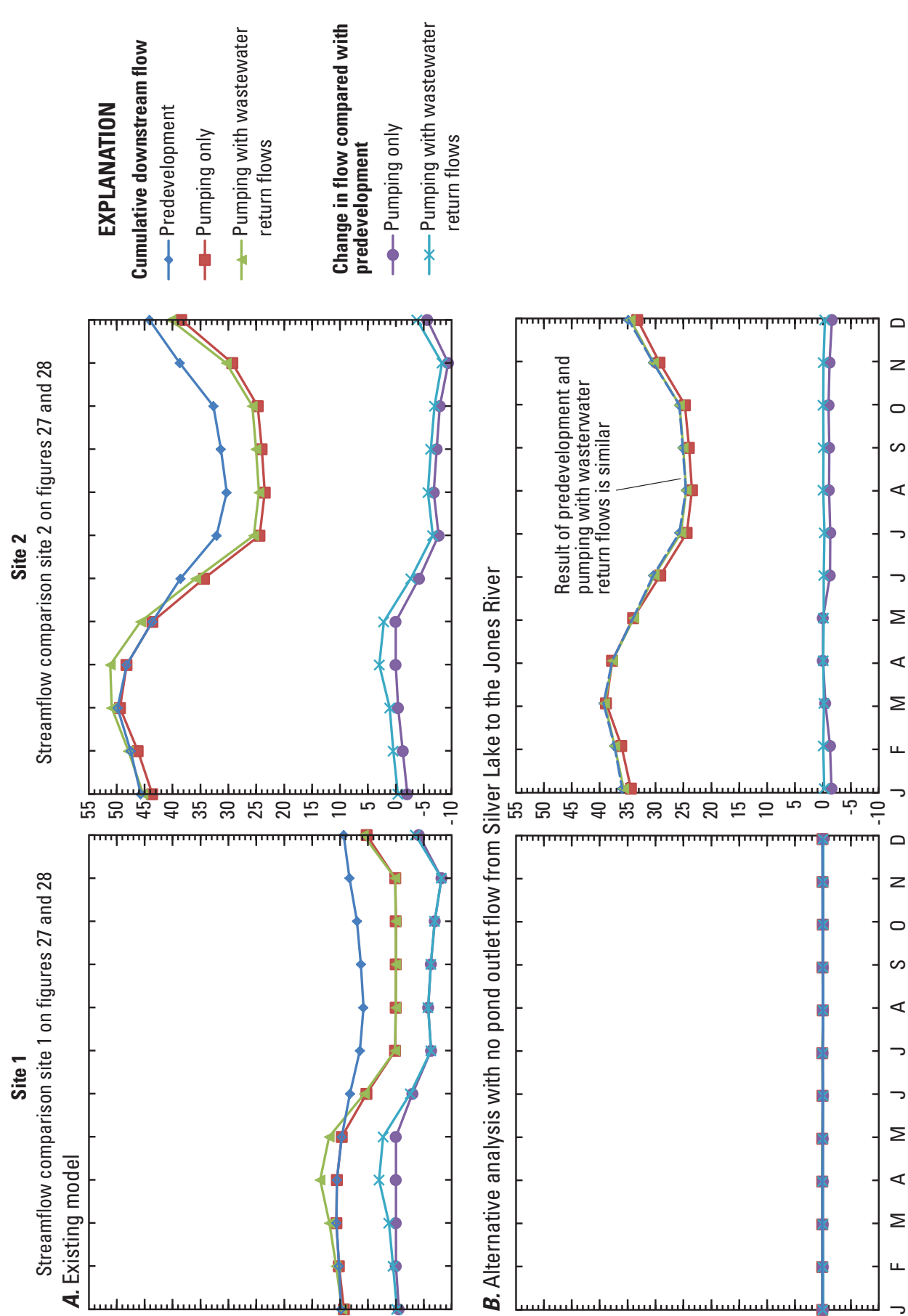

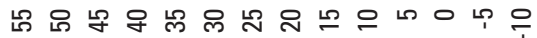

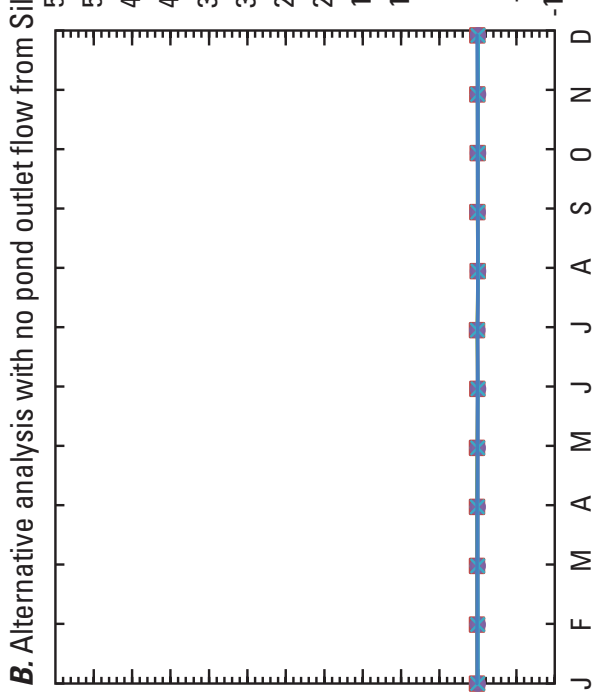

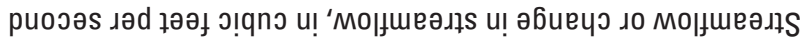

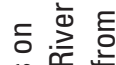

is

is

३े

竞

क 웅

要产

늠

西

品言

Ф

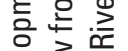

응 娄

ठ은

훙

立

돈

궁흔

한 은

要

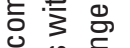

$3 \frac{\infty}{5} \frac{\pi}{5}$

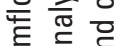

匹

密. 范

政

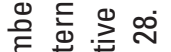

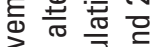

ว

폰

跑

总焉

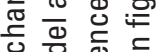

을

๙

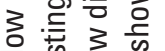

产

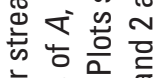

के is क

है을

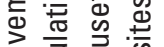

之를

o s

志 $\overline{0}$ o

言 $\sum^{\circ}$

ज就

的

รี \&

힌흠

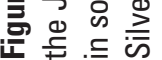


37.1- $\mathrm{ft}^{3} / \mathrm{s}$ streamflow at the downstream gage (Masterson and others, 2009). Therefore, the assumption in the PlymouthCarver regional modeling analysis was that about 22 percent of the total streamflow at the downstream gage (figs. 27 and 28 , streamflow comparison site 2) was derived from pond flow into the river. When the simulated predevelopment streamflow then was compared with the streamflow under pumping with wastewater return flow conditions, the streamflow at the downstream gage decreased by about $3.1 \mathrm{ft}^{3} / \mathrm{s}$, or about 8 percent, with $2.7 \mathrm{ft}^{3} / \mathrm{s}$ (or about 87 percent) of that decrease occurring at the pond outlet in response to pumping at Silver Lake (Masterson and others, 2009).

To better understand the effect of contributions from ponds on streamflow alteration, an alternative analysis was conducted in which pond outlet flows to receiving streams were excluded. For the alternative analysis of the Silver Lake/ Jones River system, changes in streamflows among the two streamflow comparison sites on the Jones River were assessed for November rather than for long-term average conditions. November streamflows were compared because that was the month that had the largest streamflow alteration for the existing model between the two streamflow comparison sites on the Jones River (fig. 29). For the existing model, the comparison between predevelopment and pumping with wastewater return flow conditions indicates that the depletion in the Jones River at the downstream gage (streamflow comparison site 2) is about $10 \mathrm{ft}^{3} / \mathrm{s}$ or 26 percent of the total (fig. 27); however, more than 80 percent of that reduction $\left(8.2 \mathrm{ft}^{3} / \mathrm{s}\right)$ occurred at the pond outlet, highlighting the importance of understanding the contribution of streamflow at the pond outlet to the stream for predevelopment conditions.

Given the uncertainty in model results because of the lack of data available to verify the simulated outflows from the pond, the effects of pumping only and pumping with wastewater return flows on the portion of the streamflows not associated with pond outlet flows were evaluated for the alternative analysis. For the Jones River, predevelopment November streamflow at the downstream gage (streamflow comparison site 2), not including the contribution from the pond, was $30.4 \mathrm{ft}^{3} / \mathrm{s}$ (fig. 29). For the pumping only analysis, it was $29.2 \mathrm{ft}^{3} / \mathrm{s}$, and for the pumping with wastewater return flow analysis, it was $30.3 \mathrm{ft}^{3} / \mathrm{s}$ (fig. 29). Based on this analysis, the total depletion for the Jones River at the downstream gage for pumping with wastewater return flow conditions would be 0.3 percent, compared with 22 percent when the pond flows are included (figs. 28 and 29).

Streamflows at the downstream gage that include and exclude pond outlet flows are presented in this report to illustrate the extent to which streamflow alteration results are affected by flow from the pond outlet. Had information on outflows and outlet elevation over time been available for the calibration period, this information could have been incorporated into the model (for Silver Lake and other ponds) at that time. However, the only information available was streamflow at the downstream streamgage. This example underscores the uncertainties in simulated results from regional groundwater models with incomplete historical information to inform local questions. Also highlighted is the importance of various types of measured data recorded over a long period of time and historic data collection activities that contribute to measured water level and streamflow datasets, among other things, that can be used to calibrate future groundwater models.

In addition to the Silver Lake/Jones River system in the Plymouth-Carver model area, other headwater pond/ stream systems exist in the modeled areas of southeastern Massachusetts. Table 7 shows results of the alternative analysis where there was no contribution of headwater-pond outflow to the stream for selected subbasins in the PlymouthCarver and western Cape model areas for steady-state, and January, April, August, and October streamflows. Three broad categories of results were identified from this alternative analysis: (1) the pond outflow contributes greatly to the downstream flow, (2) there is no outflow from the pond to the stream, and (3) the streamflow system is comparatively more complex because of other ponds located within the course of the stream as well as infiltration of streamflow into the aquifer sediments downstream of a pond (a losing stream). In these headwater pond/stream systems, the results of the alternative analysis were less conclusive. Two of the systems that showed the greatest difference in streamflow alteration when pond outflows were absent were the Billington Sea/Town Brook and Mashpee-Wakeby Pond/Mashpee River systems (figs. 18 and 19; table 7). In contrast, the Island Creek Pond/Island Creek and Lovells Pond/Little River systems had no pond outflow to the stream and, therefore, showed no change in the alternative analysis (figs. 18 and 19; table 7). Finally, the Halfway Pond/Agawam River system was an example of a system with greater complexity; this system had a lower streamflow at the downstream outlet point of subbasin SB-17 than at the pond outflow point because of infiltration of water from the stream into the aquifer. The alternative analysis makes use of the models as they are currently documented, but presents an alternative analysis of the simulated results for areas downstream from ponds to address the uncertainty in simulated predevelopment pond outlet flows.

In addition to uncertainties associated with calibration and the use of the groundwater models to simulate complex pond/stream systems, model error associated with the numerical solution can also exist. Model error is the collective term for differences, from a number of sources, that arise between simulated and actual hydrologic conditions (Walter and Whealan, 2005; Masterson and others, 2009). Discretization, which is the size of the model cells, is one component that can contribute to model error when the model cell size is larger than the feature being simulatedfor example, a regional groundwater model area with a grid of uniformly sized cells at $400 \mathrm{ft}$ by $400 \mathrm{ft}$, where streams of width of $20 \mathrm{ft}$ exist. In this analysis, a small number of stream cells actually showed an increase in simulated stream flow under pumping only conditions when compared with predevelopment conditions, which is unrealistic and indicative 

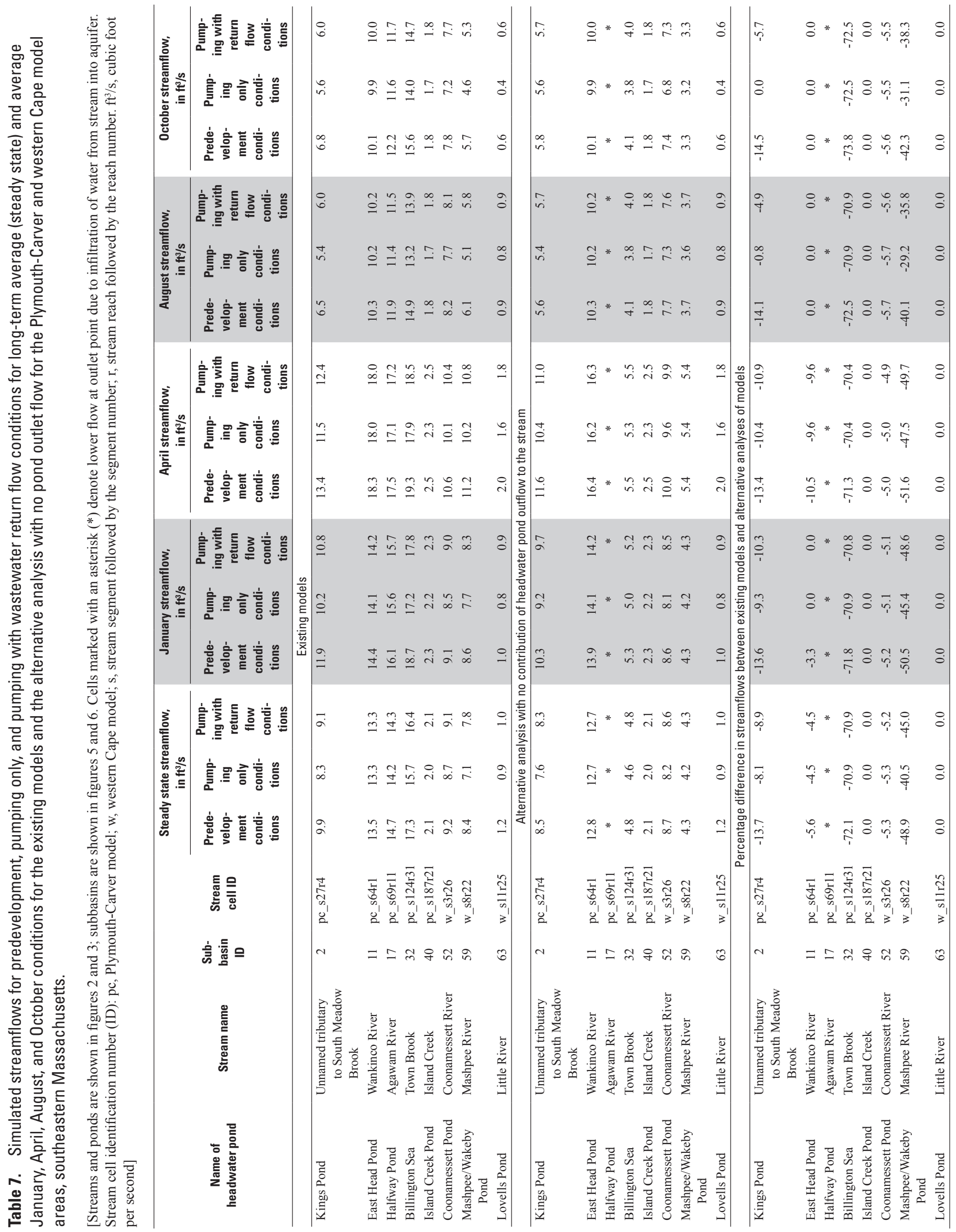
of a local model error. Where this occurred, the resulting streamflow values for pumping only conditions were set equal to the predevelopment values; the result then was no change in streamflow between predevelopment and pumping only conditions. These stream cells were noted in the transient shapefiles in field err_cfs with a value (greater than zero) that is the difference between the predevelopment value and the erroneous value for pumping only conditions in cubic feet per second. Streamflow changes in these stream cells for pumping only conditions, therefore, would have greater uncertainty than in other stream cells. Compared with the total number of stream cells, this phenomenon occurred in relatively few stream cells. The range of transient results in the Plymouth-Carver model showed that this error occurred in less than 1 percent of the stream cells in January, October, and December and about 6 percent of the stream cells in April. In the western Cape model, this error occurred in about 1 percent of the stream cells in each month. In the eastern Cape model, it occurred in about 2 percent of the stream cells for most months, with a peak of about 5 percent in November.

Time periods for pumping in the models included 2000 through 2005 for Plymouth-Carver and 2003 for western and eastern Cape Cod. Although these time periods do not exactly coincide, this difference was considered a minor limitation and was acceptable for this project. It was beyond the scope of this study to update each model for a coincident time period.

\section{Summary}

Water use, such as withdrawals, wastewater return flows, and interbasin transfers, can alter streamflow regimes, water quality, and the integrity of aquatic habitat and affect the availability of water for human and ecosystem needs. To provide the information needed to determine alteration of streamflows and pond water levels in southeastern Massachusetts, the U.S. Geological Survey, in cooperation with the Massachusetts Department of Environmental Protection, conducted a study that made use of the existing groundwater models of the Plymouth-Carver region and western (Sagamore flow lens) and eastern (Monomoy flow lens) Cape Cod. The main objective of the study was to determine the location and magnitude of changes (or alterations) in simulated streamflows and pond levels in response to pumping and wastewater return flows. Streamflow and pond-level alterations were calculated relative to a predevelopment (no pumping or wastewater return flow) baseline condition for long-term average (steady-state) and average monthly (transient) conditions. Streamflow alterations were computed at the outlets of 78 groundwater subbasins delineated in this study, and at the individual groundwater model cells used to represent the stream network in southeastern Massachusetts. Pond-level alterations were computed for each pond simulated in the study area. Selected landscape characteristics computed for the topographically derived basins in the rest of Massachusetts were also determined for the 78 groundwater subbasins delineated in this study.

The pumping and wastewater return flow locations and rates used in this study are the same as those used in previously published studies. Steady-state simulations were used to evaluate long-term average effects of pumping and wastewater return flows on water levels and streamflows, and transient simulations were used to evaluate average monthly effects. The current pumping and wastewater return flow conditions were for 2000 through 2005 for the PlymouthCarver model and 2003 for the western and eastern Cape Cod models. Although these time periods do not exactly coincide, the difference was considered minor and was acceptable for this study. The net effect of pumping and wastewater return flows on streamflows and pond levels varied by location and included no change in areas minimally affected by water use, decreases in areas affected more by pumping than by wastewater return flows, or increases in areas affected more by wastewater return flows than by pumping.

Streams in southeastern Massachusetts are relatively small compared with those in the rest of the Commonwealth. Generally, streamflow magnitudes tended to decrease with distance eastward on Cape Cod, whereas streamflows with the largest magnitude occurred in streams in the PlymouthCarver region. Maximum simulated long-term average predevelopment streamflows ranged from 13.1 cubic feet per second $\left(\mathrm{ft}^{3} / \mathrm{s}\right)$ in the eastern Cape model to $68.8 \mathrm{ft}^{3} / \mathrm{s}$ in the Plymouth-Carver model. For most of the groundwater subbasins in study area, simulated streamflows normalized by subbasin area are about 2 cubic feet per second per square mile or less.

Simulated alterations to long-term average streamflows at subbasin outlets in response to pumping with wastewater return flows ranged from a decrease (depletion) of 43.9 percent at an unnamed tributary to Salt Pond (PlymouthCarver model) to an increase (surcharge) of 18.2 percent at an unnamed tributary to Centerville River (western Cape model). However, alterations were within 10 percent of predevelopment streamflows for most of the subbasins in the study area. In general, the relative effects of pumping and wastewater return flows typically were larger in the subbasins with low streamflows than in the subbasins with high streamflows. Depleted streamflows occurred more frequently than surcharged streamflows. Increases in streamflows in response to wastewater return flows were generally largest in subbasins with a high density of septic systems or a centralized wastewater treatment facility.

For average monthly conditions, streamflow alteration results were similar spatially to results for long-term average conditions. However, differences in the extent of alteration by month were observed. Percentage streamflow depletions were larger during the low-streamflow months of August and October in most subbasins. Streamflow surcharges were more variable by month, but also were larger during the low-streamflow months in most subbasins. For the low-streamflow month of August, streamflow alterations 
ranged from a decrease of 100 percent (no streamflow conditions) at Indian Brook in the Plymouth-Carver model to an increase of 43.7 percent at an unnamed tributary to Salt Pond in the Plymouth-Carver model. However, simulated alterations of average August streamflow under pumping and wastewater return flow conditions were within 10 percent of predevelopment streamflows for most of the subbasins in the study area.

The percentages of the total number of ponds affected by pumping with wastewater return flow conditions under longterm average conditions were 28 percent for the PlymouthCarver model, 67 percent for the western Cape model, and 75 percent for the eastern Cape model. Pond-level alterations ranged from a decrease of 4.6 feet (ft) at Great South Pond in the Plymouth-Carver model to an increase of $0.9 \mathrm{ft}$ at Wequaquet Lake in the western Cape model. The magnitudes of monthly pond water level alterations were fairly consistent throughout the year.

For both long-term average and monthly streamflows, comparison of simulation results for pumping only and pumping with wastewater return flows shows that enhanced recharge resulting from wastewater return flows can either reduce the magnitude of streamflow depletion caused by pumping or, less commonly, produce surcharged streamflows that exceed predevelopment streamflows. Similarly for ponds, wastewater return flows can either reduce the magnitude of decreases in pond levels caused by pumping or produce levels that exceed predevelopment levels. Thus, wastewater return flows can have locally important effects on the extent of streamflow and pond-level alterations in southeastern Massachusetts.

Because multiple simulations were conducted over a large geographic area, this study produced an extensive set of simulation results. These results are available in appendixes 2 and 3 as geographic information system shapefiles and spreadsheets. ArcMap projects that contain the shapefiles are provided in appendixes 2 and 3. Appendix 2 contains the results of all simulations (streamflow and pond-level alteration for all water-use conditions under steady-state and transient conditions), and appendix 3 contains the landscape characteristics for the groundwater subbasins.

\section{References Cited}

Archfield, S.A., Vogel, R.M., Steeves, P.A., Brandt, S.L., Weiskel, P.K., and Garabedian, S.P., 2010, The Massachusetts sustainable yield estimator-A decision support tool to assess water availability at ungaged sites in Massachusetts: U.S. Geological Survey Scientific Investigations Report 2009-5227, 41 p. plus CD-ROM. [Also available at http://pubs.usgs.gov/sir/2009/5227/.]
Armstrong, D.S., Richards, T.A., and Levin, S.B., 2011, Factors influencing riverine fish assemblages in Massachusetts: U.S. Geological Survey Scientific Investigations Report 2011-5193, 58 p. [Also available at http://pubs.usgs.gov/sir/2011/5193/.]

Barlow, P.M., 1997, Particle-tracking analysis of contributing areas of public-supply wells in simple and complex flow systems, Cape Cod, Massachusetts: U.S. Geological Survey Water-Supply Paper 2434, 66 p. [Also available at http://pubs.er.usgs.gov/publication/ofr93159.]

Franke, O.L., Reilly, T.E., Pollock, D.W., and LaBaugh, J.W., 1998, Estimating areas contributing recharge to wells: Lessons from previous studies: U.S. Geological Survey Circular 1174, 14 p. [Also available at http://water.usgs.gov/ ogw/pubs/Circ1174/circ1174.pdf.]

Fry, J.A., Xian, George, Jin, Suming, Dewitz, J.A., Homer, C.G., Yang, Limin, Barnes, C.A., Herold, N.D., and Wickham, J.D., 2011, Completion of the 2006 national land cover database for the conterminous United States: Photogrammetric Engineering \& Remote Sensing, v. 77, no. 9, p. 858-864, accessed April 26, 2013, at http://www.mrlc.gov/nled2006.php.

Harbaugh, A.W., 2005, MODFLOW-2005, the U.S. Geological Survey modular ground-water model-The ground-water flow process: U.S. Geological Survey Techniques and Methods, book 6, chap. A16, [variously paged]. [Also available at http://pubs.usgs.gov/tm/2005/ tm6A16/.]

Harbaugh, A.W., Banta, E.R., Hill, M.C., and McDonald, M.G., 2000, MODFLOW-2000, the U.S. Geological Survey modular groundwater model-User guide to modularization concepts and the groundwater flow process: U.S. Geological Survey Open-File Report 00-92, 121 p. [Also available at http://pubs.usgs.gov/of/2000/0092/report.pdf.]

Massachusetts Department of Environmental Protection, 2014a, SWMI technical resources: Massachusetts Department of Environmental Protection Web page, accessed March 19, 2014, at http://www.mass.gov/eea/ agencies/massdep/water/watersheds/sustainable-watermanagement-initiative-swmi.html. [Includes a link to the regression equation solver, at http://www.mass.gov/eea/ docs/dep/water/resources/n-thru-y/solver.xlsm.]

Massachusetts Department of Environmental Protection, 2014b, SWMI technical resources: Massachusetts Department of Environmental Protection Web page, accessed March 19, 2014, at http://www.mass.gov/eea/ agencies/massdep/water/watersheds/sustainable-watermanagement-initiative-swmi.html. [Includes a link to the biological category statewide map, at http://www.mass.gov/ eea/docs/dep/water/resources/a-thru-m/bc.pdf] 
Massachusetts General Court, 2015, Massachusetts water management act: Massachusetts General Court Web page, accessed August 18, 2015, at https://malegislature.gov/ Laws/GeneralLaws/PartI/TitleII/Chapter21g.

Massachusetts Office of Geographic Information, 2012, MassGIS data-Dams: Massachusetts Office of Geographic Information Web page, accessed May 2, 2013, at http://www.mass.gov/anf/research-and-tech/it-serv-andsupport/application-serv/office-of-geographic-informationmassgis/datalayers/dams.html.

Masterson, J.P., Carlson, C.S., and Walter, D.A., 2009, Hydrogeology and simulation of groundwater flow in the Plymouth-Carver-Kingston-Duxbury aquifer system, southeastern Massachusetts: U.S. Geological Survey Scientific Investigations Report 2009-5063, 110 p. [Also available at http://pubs.er.usgs.gov/publication/ sir20095063.]

Masterson, J.P., and Walter, D.A., 2000, Delineation of ground-water recharge areas, western Cape Cod, Massachusetts: U.S. Geological Survey Water-Resources Investigation Report 00-4000, 1 sheet. [Also available at http://pubs.er.usgs.gov/publication/wri004000.]

Masterson, J.P., and Walter, D.A., 2009, Hydrogeology and groundwater resources of the coastal aquifers of southeastern Massachusetts: U.S. Geological Survey Circular 1338, 16 p. [Also available at http://pubs.usgs.gov/ circ/circ1338/.]

Masterson, J.P., Walter, D.A., and LeBlanc, D.R., 1998, Delineation of contributing areas to selected public-supply wells, western Cape Cod, Massachusetts: U.S. Geological Survey Water-Resources Investigations Report 98-4237, 45 p. [Also available at http://pubs.er.usgs.gov/publication/ wri984237.]

McDonald, M.G., and Harbaugh, A.W., 1988, A modular three-dimensional finite-difference groundwater flow model: U.S. Geological Survey Techniques of WaterResources Investigations, book 6, chap. A1, 586 p. [Also available at http://pubs.usgs.gov/twri/twri6a1/.]
Pollock, D.W., 1994, User's guide for MODPATH/ MODPATH-PLOT, version 3; a particle tracking postprocessing package for MODFLOW, the U.S. Geological Survey finite-difference groundwater flow model: U.S. Geological Survey Open-File Report 94-464, 234 p. [Also available at http://pubs.er.usgs.gov/publication/ofr94464.]

Prudic, D.E., 1989, Documentation of a computer program to simulate stream-aquifer relations using a modular, finitedifference, groundwater flow model: U.S. Geological Survey Open-File Report 88-729, 113 p. [Also available at http://pubs.er.usgs.gov/publication/ofr88729.]

Walter, D.A., and Masterson, J.P., 2011, Estimated hydrologic budgets of kettle-hole ponds in coastal aquifers of southeastern Massachusetts: U.S. Geological Survey Scientific Investigations Report 2011-5137, 72 p. [Also available at http://pubs.usgs.gov/sir/2011/5137/.]

Walter, D.A., Masterson, J.P., and Hess, K.M., 2004, Groundwater recharge areas and travel times to pumped wells, ponds, streams, and coastal water bodies, Cape Cod, Massachusetts: U.S. Geological Survey Scientific Investigations Map I-2857, 1 sheet. [Also available at http://pubs.usgs.gov/sim/2004/2857/.]

Walter, D.A., and Whealan, A.T., 2005, Simulated water sources and effects of pumping on surface and ground water, Sagamore and Monomoy flow lenses, Cape Cod, Massachusetts: U.S. Geological Survey Scientific Investigations Report 2004-5181, 85 p., http://pubs.usgs.gov/sir/2004/5181/.

Weiskel, P.K., Brandt, S.L., DeSimone, L.A., Ostiguy, L.J., and Archfield, S.A., 2010, Indicators of streamflow alteration, habitat fragmentation, impervious cover, and water quality for Massachusetts stream basins: U.S. Geological Survey Scientific Investigations Report 20095272, 70 p. plus CD-ROM. [Also available at http://pubs.usgs.gov/sir/2009/5272/.] 



\title{
Appendix 1. Development of Transient Groundwater Models for Cape Cod
}

\author{
Appendix 2. Simulated Changes to Streamflows and \\ Pond Levels
}

\section{Appendix 3. Landscape Characteristics in Simulated Groundwater Contributing Areas to Streams}

[ZIP files of shapefiles and spreadsheet files for appendixes 2 and 3 are available separately at http://dx.doi.org/10.3133/sir20155168.] 


\section{Appendix 1. Development of Transient Groundwater Models for Cape Cod}

A sequence of models for Cape Cod (fig. 1-1) has been developed from previously published investigations. The original versions of the western Cape (Sagamore flow lens) and eastern Cape (Monomoy flow lens) models were documented in Walter and Whealan (2005). A subsequent investigation by Walter and Masterson (2011) estimated hydrologic budgets for 425 ponds and modified the areas that represented ponds in the steady-state models of Walter and Whealan (2005); modifications were made to more accurately match actual conditions. The modifications by Walter and Masterson (2011) include changes to the Layer-Property Flow (LPF) package (Harbaugh and others, 2000) of the U.S. Geological Survey's three-dimensional finite-difference groundwater model MODFLOW in areas of ponds to more accurately simulate the geometry of certain ponds and to include additional ponds not previously represented, as well as to the Streamflow-Routing (STR) package (Prudic, 1989) to more accurately represent the interaction of certain streams with ponds. The steady-state models documented in Walter and Masterson (2011) were used in this study; however, Walter and Masterson (2011) did not produce updated transient models. Because the areas that represented ponds were more accurately simulated by the changes documented in Walter and Masterson (2011), transient versions of these models would be better suited for the current analysis. In brief, to incorporate the modifications made by Walter and Masterson (2011), the updated pond areas - essentially areas of infinite hydraulic conductivity—were combined with the existing transient hydrologic boundary conditions, storage properties of the aquifer sediments, and hydraulic stresses, as documented in Walter and Whealan (2005). This combination produced updated transient models of western and eastern Cape Cod. Finally, Walter and Masterson (2011) document the most recent steady-state versions and this report documents the most recent transient versions of the western and eastern Cape Cod models.

To document the similarity of results between the existing transient versions of the western and eastern Cape Cod models in Walter and Whealan (2005) and the transient versions modified for this report, pond levels and streamflows were compared. Three long-term streamflow monitoring sites located in the study areas were used to compare simulated streamflows: the Herring River in the eastern Cape model and the Quashnet River and Mill Creek in the western Cape model (fig. 3). A discussion of the comparison of streamflow data collected in May 2002 and the agreement with longterm mean and median streamflow estimates are available in Walter and Whealan (2005, appendix 1). Walter and Whealan (2005) indicate that in the Herring River the long-term mean and median flow values were 9.9 and 8.6 cubic feet per second $\left(\mathrm{ft}^{3} / \mathrm{s}\right)$, respectively, with a measured streamflow in May 2002 of $7.7 \mathrm{ft}^{3} / \mathrm{s}$. These values compare to simulated May streamflow values of $7.0 \mathrm{ft}^{3} / \mathrm{s}$ from Walter and Whealan (2005) and $9.0 \mathrm{ft}^{3} / \mathrm{s}$ from the transient model modified for this report. This difference of $2.0 \mathrm{ft}^{3} / \mathrm{s}$ can be attributed to an increase in flow out of Hinckleys Pond of $2.0 \mathrm{ft}^{3} / \mathrm{s}$, which was caused by

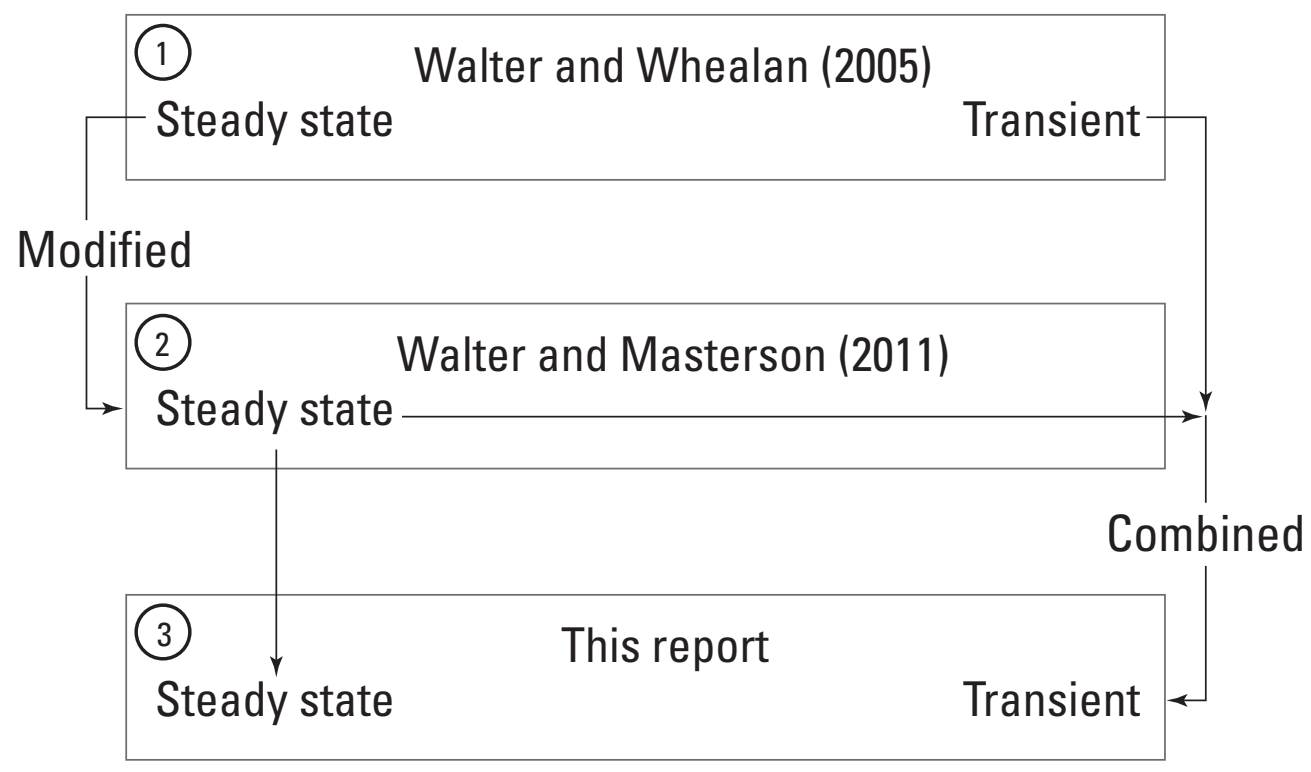

Figure 1-1. The evolution of the western Cape (Sagamore flow lens) and eastern Cape (Monomoy flow lens) models of Cape Cod in southeastern Massachusetts. 
the manner in which ponds were represented in Walter and Masterson (2011). In the western Cape model, streamflow measured in May 2002 on the Quashnet River was $15.3 \mathrm{ft}^{3} / \mathrm{s}$, which was close to the long-term mean and median values of 15.8 and $15.3 \mathrm{ft}^{3} / \mathrm{s}$, respectively (Walter and Whealan, 2005). The simulated May streamflow on the Quashnet River of $17.2 \mathrm{ft}^{3} / \mathrm{s}$ was the same in both Walter and Whealan (2005) and the transient model modified for this report. In Mill Creek, at the outlet of Lower Shawme Lake, the measured streamflow of $6.3 \mathrm{ft}^{3} / \mathrm{s}$ was similar to the mean and median streamflows of $6.4 \mathrm{ft}^{3} / \mathrm{s}$. The simulated May streamflows on Mill Creek were 7.3 and $7.2 \mathrm{ft}^{3} / \mathrm{s}$ from Walter and Whealan (2005) and the transient model modified for this report, respectively. These comparisons show that the simulated streamflows were similar between the original and modified transient versions of the models.

Simulated pond water levels from Walter and Whealan (2005) and this study (using the updated, transient version of the Walter and Whealan [2005] model) were compared for selected ponds: Coles Pond and Paddocks Pond from the eastern Cape model, and Ashumet Pond and Mary Dunn Pond from the western Cape model (fig. 1-2). These hydrographs

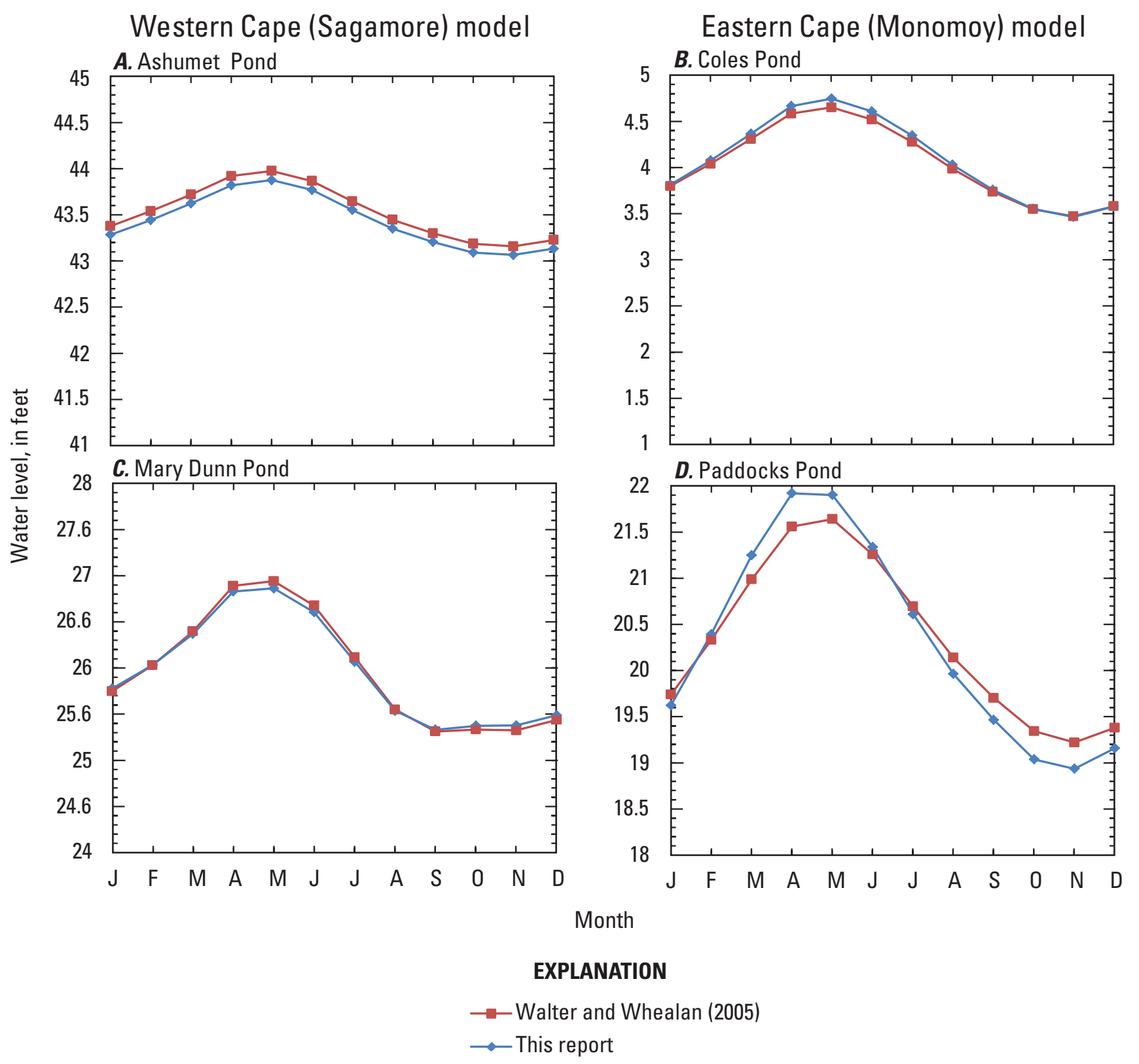

Figure 1-2. Comparison of simulated pond levels between Walter and Whealan (2005) and the updated transient models (this report) for $A$, Ashumet Pond, $B$, Coles Pond, $C$, Mary Dunn Pond, and $D$, Paddocks Pond in southeastern Massachusetts. 
show that the largest monthly differences were 0.09 feet ( $\mathrm{ft}$ ) in June at Coles Pond; $0.36 \mathrm{ft}$ in April at Paddocks Pond; a consistent $0.1 \mathrm{ft}$ for most of the year at Ashumet Pond; and $-0.08 \mathrm{ft}$ in May at Mary Dunn Pond. Simulated seasonality and magnitude of pond levels compared favorably between the results of Walter and Whealan (2005) and the updated transient models used for this study. The model archive for this report will include the steady-state versions used in Walter and Masterson (2011) and the transient versions developed for this analysis.

\section{References Cited}

Harbaugh, A.W., Banta, E.R., Hill, M.C., and McDonald, M.G., 2000, MODFLOW-2000, the U.S. Geological Survey modular groundwater model - User guide to modularization concepts and the groundwater flow process: U.S. Geological Survey Open-File Report 00-92, 121 p. [Also available at http://pubs.usgs.gov/of/2000/0092/report.pdf.]

Masterson, J.P., Carlson, C.S., and Walter, D.A., 2009, Hydrogeology and simulation of groundwater flow in the Plymouth-Carver-Kingston-Duxbury aquifer system, southeastern Massachusetts: U.S. Geological Survey Scientific Investigations Report 2009-5063, 110 p. [Also available at http://pubs.er.usgs.gov/publication/ sir20095063.]

Prudic, D.E., 1989, Documentation of a computer program to simulate stream-aquifer relations using a modular, finitedifference, groundwater flow model: U.S. Geological Survey Open-File Report 88-729, 113 p. [Also available at http://pubs.er.usgs.gov/publication/ofr88729.]

Walter, D.A., and Masterson, J.P., 2011, Estimated hydrologic budgets of kettle-hole ponds in coastal aquifers of southeastern Massachusetts: U.S. Geological Survey Scientific Investigations Report 2011-5137, 72 p., http://pubs.usgs.gov/sir/2011/5137/.

Walter, D.A., and Whealan, A.T., 2005, Simulated water sources and effects of pumping on surface and ground water, Sagamore and Monomoy flow lenses, Cape Cod, Massachusetts: U.S. Geological Survey Scientific Investigations Report 2004-5181, 85 p. [Also available at http://pubs.usgs.gov/sir/2004/5181/.] 


\section{Appendix 2. Simulated Changes to Streamflows and Pond Levels}

Simulated changes to streamflows are available in this analysis for each stream cell (individual model cell), and simulated changes in pond levels are available for each pond. The diagram in figure $2-1$ graphically shows the complete monthly (January through December) and steady-state results that are available for pumping only and pumping with wastewater return flow conditions for all streams at the outlets of the subbasins, for individual stream cells, and for all ponds in the model areas. These results are in the shapefiles and spreadsheet files of this appendix (available for download at http://dx.doi.org/10.3133/sir20155168). Use of the shapefiles in the accompanying ArcMap project will allow close inspection of results for individual streams and ponds. The predevelopment, pumping only, and pumping with wastewater return flow streamflow and pond water level results from which changes were calculated are included in the shapefiles and spreadsheet files. The metadata contained within each shapefile provide additional information on shapefile contents. Streamflow output from model simulations includes the outflow component from each stream cell for predevelopment, pumping only, and pumping with wastewater return flow conditions in cubic feet per day.

The ArcMap project included in this appendix contains all of the shapefiles for changes in simulated streamflows and pond levels. The dataset for changes in simulated streamflows includes 13 shapefiles - one shapefile for each month for January through December and one for the steady-state simulations - for each model area. Each of those 13 shapefiles contains the simulated cumulative streamflows for each stream cell for predevelopment, pumping only, and pumping with wastewater return flow conditions, and the simulated changes in streamflow due to pumping only and pumping with wastewater return flow conditions in comparison to predevelopment conditions in cubic feet per second and percentage change. Because each shapefile includes results for all conditions, the same shapefiles appear four times in the ArcMap project, and each appearance displays a different field or result. Three spreadsheet tables are also included that contain the same results as the shapefiles. The dataset for changes in simulated pond levels is similar to that for streamflows except that changes due to pumping only and for pumping with wastewater return flows are provided in feet and that the same shapefiles appear only two times in the ArcMap project for display purposes.

Additional ancillary data are also included with the datasets. Other geographic information system shapefiles included as ancillary data are locations of streamflow monitoring sites and the outline of the overall extent of each groundwater model area. 
Results of groundwater model simulations for changes to streamflows and pond water levels: sir20155168_appendix2_gis.zip

Folder: ..Appendix2lGIS_and_spreadsheets_streams_and_ponds\

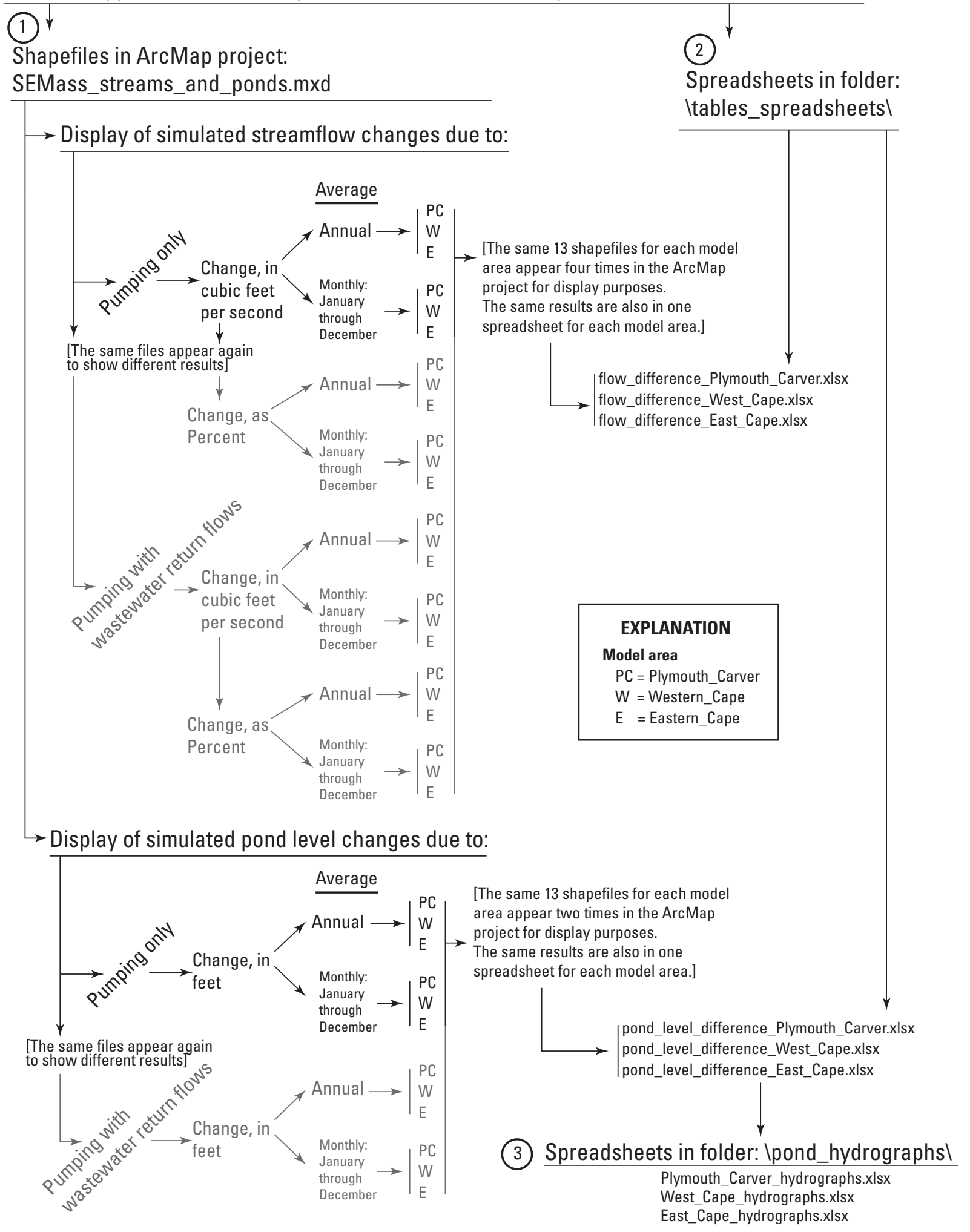

Figure 2-1. The shapefiles and spreadsheet files that accompany this report and represent the simulated changes in streamflows and pond levels in the Plymouth-Carver, western Cape, and eastern Cape model areas in southeastern Massachusetts. 


\section{Appendix 3. Landscape Characteristics in Simulated Groundwater Contributing Areas to Streams}

This appendix includes the shapefiles and spreadsheet files (available for download at http://dx.doi.org/10.3133/ sir20155168) that contain results of the landscape characteristic determinations for the contributing areas (subbasins and hydrologic units). The diagram in figure 3-1 graphically shows the names of the files in this appendix. The procedure used to delineate the groundwater subbasins is discussed in the "Development of Contributing Areas" section of this report. Ancillary data are also included with the datasets. Additional attributes in the files include the area and originating groundwater model, the simulated long-term average predevelopment streamflows at the outlets of the subbasins and hydrologic units, and simulated long-term average streamflows normalized by the subbasin area. Other geographic information system shapefiles included as ancillary data include a polygon file of the model cells that correspond to the outlets of the contributing area (subbasin and [or] hydrologic unit), a polygon file of the pond and stream cells that correspond to the stream subsections or lengths along a stream between outlet points from which the areas of the hydrologic units were obtained, the locations of the streamflow monitoring sites from the original studies, and the outline of the overall extent of each groundwater model area.

The ArcMap project included in this appendix contains all of the shapefiles for the landscape characteristics. The dataset for the landscape characteristics of the groundwater contributing areas includes two shapefiles, one group of shapefiles, and two tables. One shapefile contains the 61 headwater subbasins and includes the landscape values provided in table 3 of this report. The group of shapefiles consists of one shapefile for each of the 17 subbasins and includes the landscape values provided in table 3 . Another shapefile contains the percent impervious cover values determined for the 78 hydrologic units that are also provided in table 4. 
Landscape characteristics of simulated groundwater contributing areas to streams:

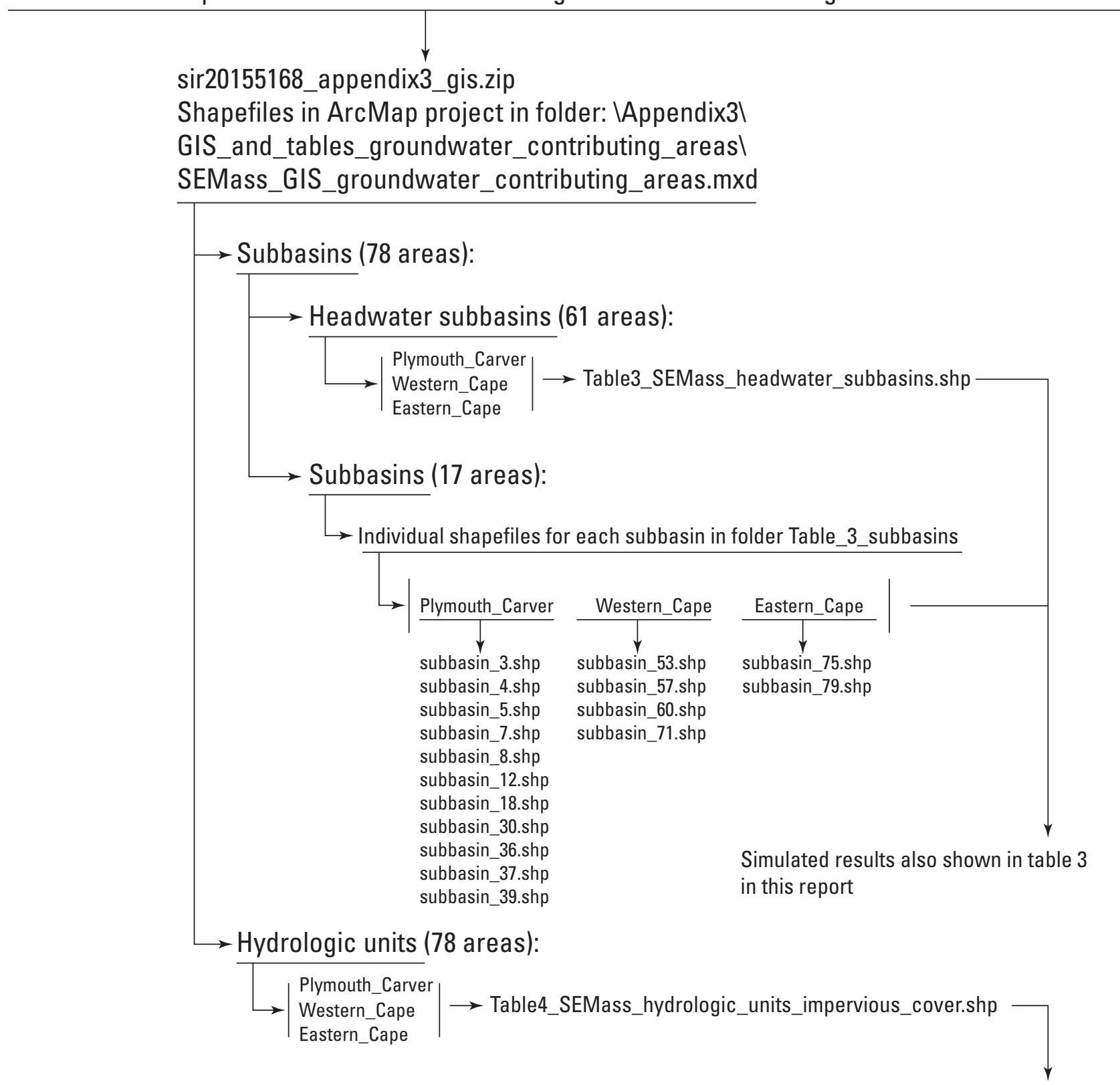

Simulated results also shown in table 4 in this report

Figure 3-1. The shapefiles and spreadsheet files that accompany this report and represent the landscape characteristics for the groundwater contributing areas to streams in the Plymouth-Carver, western Cape, and eastern Cape model areas in southeastern Massachusetts. 
For more information concerning this report, contact: Director, New England Water Science Center U.S. Geological Survey 10 Bearfoot Road Northborough, MA 01532 dc_nweng@usgs.gov or visit our Web site at: http://newengland.water.usgs.gov

Publishing support by:

The Pembroke Publishing Service Center. 


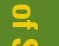

超

(1)

言

偝

实

㱐 